Y KUŞAĞININ ETNOSENTRİK EĞİLIMLERE GÖRE YERLİ VE YABANCI ÜRÜNLERE KARŞI SATIN ALMA DAVRANIŞI:

AFYONKARAHISAR ÖRNEĞİ

Gizem BÜYÜKKALAYCI

Yüksek Lisans Tezi

Danışman: Prof. Dr. Yusuf KARACA

Temmuz, 2018

Afyonkarahisar 
T.C.

AFYON KOCATEPE ÜNIVERSITESI

SOSYAL BİLİMLER ENSTITTÜSÜ

İŞLTME ANABİLIM DALI

YÜKSEK LİSANS TEZI

\title{
Y KUŞAĞININ ETNOSENTRİK EĞILIMMLERE GÖRE YERLİ VE YABANCI ÜRÜNLERE KARŞI SATIN ALMA DAVRANIŞI: AFYONKARAHISAR ÖRNEĞİ
}

\author{
Hazırlayan \\ Gizem BÜYÜKKALAYCI
}

Danışman

Prof. Dr. Yusuf KARACA

AFYONKARAHISAR 2018 


\section{YEMIN METNi}

Yüksek Lisans tezi olarak sunduğum "Y Kuşağının Etnosetrik Eğilimlere Göre Yerli ve Yabancı Ürünlere Karşı Satın Alma Davranışı: Afyonkarahisar Örneği” adlı çalışmanın, tarafımdan bilimsel ahlak ve geleneklere aykırı düşecek bir

yardıma başvurmaksızın yazıldığını ve yararlandığım eserlerin Kaynakça 'da gösterilen eserlerden oluştuğunu, bunlara atıf yapılarak yararlanmış olduğumu belirtir ve bunu onurumla doğrularım. 


\section{TEZ JÜRİSİ KARARI VE ENSTITÜ MÜDÜRLÜĞÜ ONAYI}

JÜRİ ÜYELERİ

İMZA

Tez Danışmanı : Prof. Dr. Yusuf KARACA

Jüri Üyeleri Dr. Öğr. Üyesi Ayşe ÖZGÖZ

: Dr. Öğr. Üyesi Bekir KÖSE

İşletme anabilim dalı yüksek lisans öğrencisi Gizem Büyükkalaycı'nın "Y Kuşağının Etnosentrik Eğilimlere Göre Yerli ve Yabancı Ürünlere Karşı Satın Alma Davranışı: Afyonkarahisar Örneği” başlıklı tezi 27/07/2018 tarihinde, saat 15.00'da Lisansüstü Eğitim Öğretim ve Sınav Yönetmeliğinin ilgili maddeleri uyarınca, yukarıda isim ve imzaları bulunan jüri üyeleri tarafından değerlendirilerek kabul edilmiştir.

Prof. Dr. Celal DEMIR

Sosyal Bilimler Enstitü Müdürü 


\title{
Y KUŞAĞININ ETNOSENTRIKK EĞİLIMLERE GÖRE YERLİ VE YABANCI ÜRÜNLERE KARŞI SATIN ALMA DAVRANIŞI: \\ AFYONKARAHISAR ÖRNEĞİ
}

\author{
Gizem BÜYÜKKALAYCI
}

\author{
AFYON KOCATEPE ÜNIVERSITESI \\ SOSYAL BILIIMLER ENSTITÜSÜ \\ IŞLETME ANABÍLIM DALI
}

\section{Temmuz 2018}

\section{Danışman: Prof. Dr. Yusuf Karaca}

Küreselleşmenin hızla yayılması ve uluslararası pazarın gelişmesi ile birlikte dünyanın bir ucunda üretilen ürün, dünyanın diğer ucundaki tüketiciye kolayca ulaştırılabilmektedir. Ülkeler arası ürün giriş ve çıkışının kolaylaştığı bu zamanda firmalar girecekleri pazarda bazı problemler ile karşılaşabilmektedir. $\mathrm{Bu}$ problemlerden bir tanesi de tüketici etnosentrizmidir. Tüketici Etnosentrizm kavramı yabancı ürün kullanımının ahlaki açıdan uygun olup olmadığını tartışmakta olup yabancı ürün yerine yerli ürün tercih etme eğilimi olarak ifade edilebilir. Yabancı firmaların girecekleri pazarda etnosentrik eğilimlerinin yüksek olması o firmanın ürünlerine karşı ön yargı ile yaklaşılmasına sebep olmaktadır. Başka ülkelerin pazarına girmek isteyen yabancı firmaların, o pazardaki tüketicilerin etnosentrik eğilim düzeylerini bilmeleri ve ona uygun pazarlama stratejileri geliştirmeleri kendilerine rekabet avantajı sağlayacaktır.

Çalışmada Y kuşağı üyelerinin demografik özellikleri ile etnosentrik eğilimleri arasındaki ilişki incelenmektedir. Bu kuşak üyelerinin yerli ve yabancı ürünlere karşı etnosentrik eğilim düzeyleri belirlenip market, mağaza ve pahalı -lüks olarak kategorize edilmiş ürünlere karşı tutum ve davranışları incelenerek etnosetntrizm ile ilişkisine bakılmaktadır. Araştırmada elde edilen veriler "kolayda 
örneklem yolu" ile Afyonkarahisar ilinde yaşayan 500 Y kuşağı üyelerinden, anket yöntemi ile toplanmıştır. Toplanan verilerde istatistiksel analizlerin yapılma aracı olan SPSS programı kullanılıp analiz edilirken frekans, ortalama, yüzde alma gibi yöntemler kullanılmıştır. Normal dağılım gösteren üç ve üzeri grupların analizi için One-Way Anova Testi, niteliksel verilerin analizinde ise Pearson Ki-Kare Testi kullanılarak veriler analiz edilmiş ve yorumlanmıştır. Yapılan analizlere göre $\mathrm{Y}$ kuşağı üyelerinin orta düzeyde etnosentrik eğilimlere sahip oldukları saptanmıştır.

Anahtar Kelimeler: Etnosentrizm, tüketici etnosentrizmi, Y kuşağı, yerli ürün, yabanc1 ürün. 


\title{
ABSTRACT \\ PURCHASING BEHAVIOR OF Y GENERATION TOWARDS DOMESTIC AND FOREIGN PRODUCTS BASED ON ETNOCENTRIC TENDENCIES: AFYONKARAHISAR SAMPLE
}

\author{
Gizem BÜYÜKKALAYCI
}

\author{
AFYON KOCATEPE UNIVERSITY \\ THE INSTITUETE OF SOCIAL SCIENCES \\ DEPARMENT OF BUSINESS ADMINISTRATION
}

July 2018

\section{Advisor: Prof. Dr. Yusuf KARACA}

With the rapid spread of globalization and the development of the international market, a product at one end of the world can easily be delivered to a consumer at the other end of the world. At this time, as the entry and exit of products between countries is quite facilitated, firms may encounter some problems in new markets. One of these problems is consumer ethnocentrism. The concept of consumer ethnocentrism discusses whether the use of foreign products is morally appropriate and can be expressed as the tendency to prefer domestic products instead of foreign products. The high ethnocentric tendency in the markets to which foreign firms are to penetrate leads to the prejudice against the products of those firms. Foreign companies aiming to enter the market of other countries will gain competitive advantage by learning the ethnocentric tendency levels of the consumers in that market and developing appropriate marketing strategies.

In the study, the relationship between demographic characteristics and ethnocentric tendencies of $\mathrm{Y}$ generation members is examined. The levels of ethnocentric tendency of these generation members against domestic and foreign products have been determined. Attitudes and behaviours towards products categorized as shop-store and expensive-luxury have been examined and the relationship between them and ethnocentrism has been examined. The data obtained 
in the survey were collected by means of the questionnaire from members of $500 \mathrm{Y}$ generation living in Afyonkarahisar province through "convenience sampling method". The methods such as frequency, mean, percentage were used when analyzing SPSS program which is the means of making statistical analyzes in collected data. One-Way ANOVA test was used for the analysis of three or more groups with normal distribution, and Pearson Chi-Square test was used for the analysis of qualitative data. As a result, it is found that $\mathrm{Y}$ generation members have moderate ethnocentric tendencies.

Key words: Ethnocentrism, consumer ethnocentrism, Y generation, domestic product, foreign product. 


\section{ÖNSÖZ}

$\mathrm{Bu}$ tezin hazırlanma sürecindeki her aşamada değerli bilgi, birikim ve tecrübeleri ile bana yol gösteren tez danı̧̧man hocam sayın Prof. Dr. Yusuf KARACA'ya;

Tezimin savunmasında değerli katkı ve fikirleri ile görev yapan jüri üyelerim sayın Dr. Öğr. Üyesi Ayşe ÖZGÖZ ve Dr. Öğr. Üyesi Bekir KÖSE’ye;

Tezimin hazırlanma evresinde kıymetli zamanlarını ayırarak yardımlarını bir an olsun esirgemeyen değerli hocalarım sayın Dr. Öğr. Üyesi Volkan YÜNCÜ ve Öğr. Gör. Burak OLUR'a;

Tez hazırlama süreci boyunca hep yanımda olan desteklerini bir an olsun esirgemeyen kıymetli arkadaşlarım Saliha SARGIN'a, Sümeyye EVRAN'a ve kuzenim Nur KÜÇÜKELÇİye;

Hayatım boyunca fedakârlık ve destekleri ile her zaman yanımda olan kıymetli ailem, Eyüp BÜYÜKKALAYCI'ya, Ayșe BÜYÜKKALAYCI'ya, Selahattin BÜYÜKKALAYCI'ya, Zeynep BÜYÜKKALAYCI'ya ve Erkan BÜYÜKKALAYCI'ya;

Teşekkürü bir borç bilir ve saygılarımı sunarım.

Gizem BÜYÜKKALAYCI

Afyonkarahisar, Temmuz 2018 


\section{IÇCINDEKIILER}

YEMIN METNI ........................................................................................................i

TEZ JÜRİSİ KARARI VE ENSTITÜ MÜDÜRLÜĞÜ ONAYI .............................ii

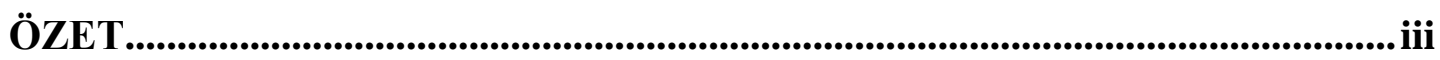

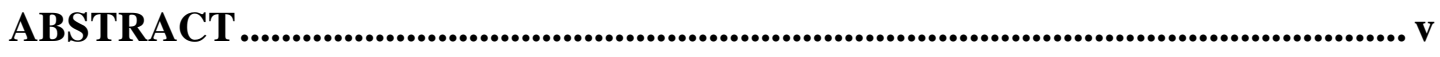

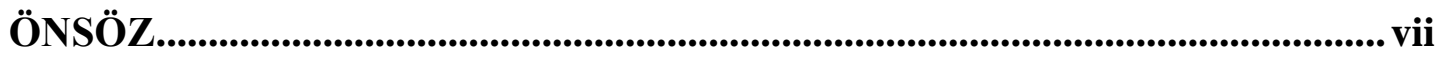

İÇINDEKILER ............................................................................................................... viii

TABLOLAR LISTESİ.............................................................................................. xi

GIRIŞ ................................................................................................................ 1

BİRINCİ BÖLÜM

ETNOSENTRIZM VE TÜKETICI ETNOSENTRIZMİ

1.ETNOSENTRIZM KAVRAMI ..............................................................................5

1.1.TÜKETICI ETNOSENTRIZMİ ......................................................................... 7

1.2.TÜKETICII ETNOSENTRIZM'IN ISSSETME VE PAZARLAMA AÇISINDAN

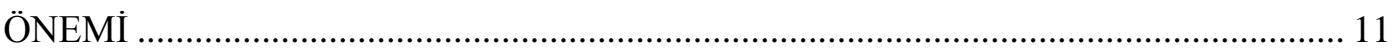

1.3. TÜKETICI ETNOSENTRIZMINI ETKILEYEN FAKTÖRLER ............................... 14

1.3.1. Demografik faktörler ................................................................................................... 15

1.3.2. Sosyal Psikolojik Faktörler ............................................................................................. 17

1.3.3.Ekonomik Faktörler ............................................................................................................ 21

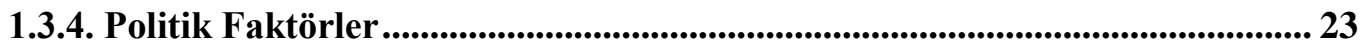

2. TÜKETICI ETNOSENTRİZM'IN ÜLKE MENŞE İLE İLISSKISİ .................24

2.1. TÜKETİCILERIN YERLİ VE YABANCI ÜRÜNLERE YÖNELIKK TUTUM VE

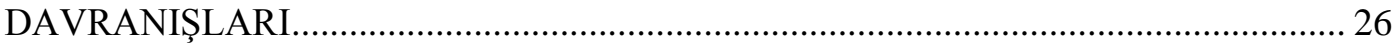

3. TÜKETICII ETNOSENTRIZZM GELIŞTIRILLMESI VE CETSCALE ÖLÇEĞİ.................................................................................................................... 29

İKİNCİ BÖLÜM

KUŞAKLAR VE Y KUŞAĞININ ÖZELLÍKLERİ

1. KUŞAK KAVRAMI .............................................................................................31

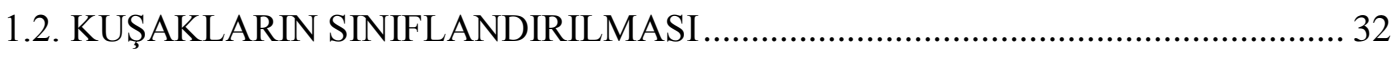

1.2.1. Sessiz Kuşak .................................................................................................................................... 34 
1.2.3. X Kuşağı............................................................................................................................. 36

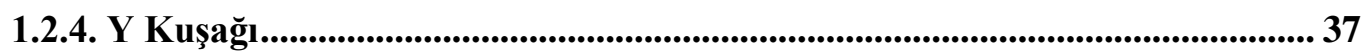

1.2.5. Z Kuşă̆

1.3. TÜKETİCI DAVRANIŞLARINDA VE PAZARLAMANDA KUŞAK KAVRAMININ ÖNEMİ 41

2. Y KUŞAĞIININ ÖZELLİKLERİ ........................................................................... 44

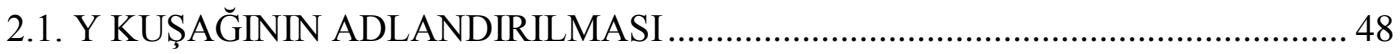

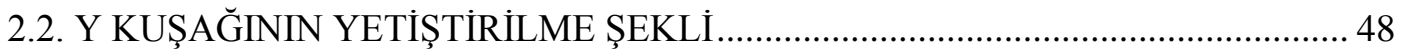

2.3. Y KUŞAĞININ HAYATA BAKIŞ AÇISI ............................................................ 49

2.4. Y KUŞAĞININ PAZARLAMADAKİ ÖNEMİ...................................................... 50

2.5. Y KUŞAĞININ TÜKETIM ALIŞKANLIKLARI ..................................................... 51

2.6. Y KUŞAĞININ SATIN ALMA DAVRANIŞI ........................................................ 53

2.7. Y KUŞAĞININ ETNOSENTRIK EĞILIMLERİ .................................................... 56

\section{ÜÇÜNCÜ BÖLÜM}

Y KUŞAĞININ ETNOSENTRİK EĞİLIMLERE GÖRE YERLİ VE YABANCI ÜRÜNLERE KARŞI SATIN ALMA DAVRANIŞI ÜZERINE AFYONKARAHİSAR ILIINDE BİR UYGULAMA

1.ARAŞTIRMANIN ÖNEMİ.................................................................................5 59

2. ARAŞTIRMANIN AMACI.....................................................................60

3. ARAŞTIRMA YÖNTEMİ .........................................................................60

3.1. ARAŞTIRMANIN ANA KÜTLESİ VE ÖRNEKLEM SEÇİMİ................................ 60

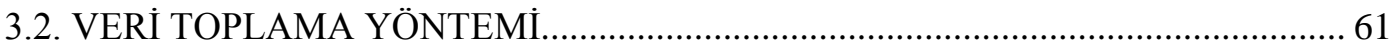

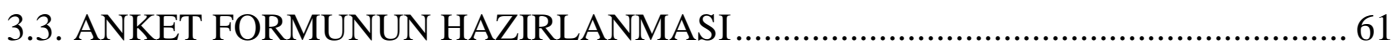

3.4. ARAŞTIRMADA KULLANILAN İSTATISTIKSSEL YÖNTEMLER ....................... 62

4. ARAŞTIRMA HIPOTEZLERİ ........................................................................63

5. ARAŞTIRMA BULGU VE YORUMLARI................................................65

5.1. Y KUŞAĞININ TEMEL KARAKTERISTIK VE DEMOGRAFIK

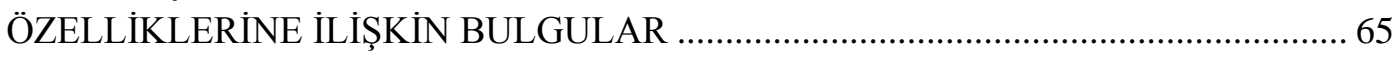

5.2. Y KUŞAĞININ YABANCI ÜRÜN YARGISI VE SATIN ALMA NIYET

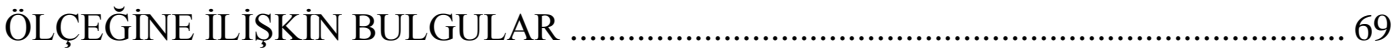

5.3. Y KUŞAĞININ SINIFLANDIRILMIŞ ÜRÜN GRUPLARINA İLIŞKINN

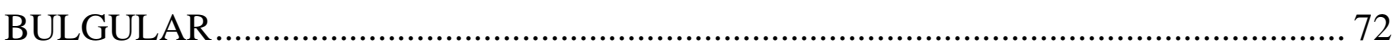

5.4. Y KUŞAĞININ ETNOSENTRIK EĞİLIMLERINE İLIŞKİN BULGULAR ........... 79

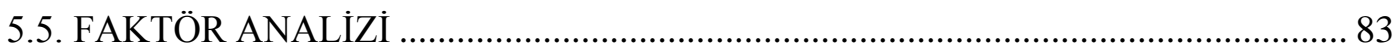


5.6.1.Demografik Özellikler ile Etnosentrizm Arasındaki İlişki............................... 87

5.6.2.Y Kuşağının Etnosentrik Eğilim Düzeyleri ile Ürün Yargısı ve Satın Alma Niyeti Arasındaki İlişki..........................................................................................994

5.6.3.Y Kuşağının Etnosentrik Eğilim Düzeyleri ile Market Ürünleri Satın Alma Davranışı Arasındaki İlişkisi............................................................................................... 95

5.6.4.Y Kuşağının Etnosentrik Eğilim Düzeyleri ile Mağaza Ürünleri Satın Alma Davranışı Arasındaki İlişkisi.............................................................................................96

5.6.5.Y Kuşağının Etnosentrik Eğilim Düzeyleri ile Pahalı ve Lüks Ürün Satın Alma Davranışı Arasındaki İlişkisi 97

5.6.6.Menşe Ülke Etkisi ile Yabancı Ürün Yargısı Satın Alma Niyeti Arasındaki İlişki .98

5.6.7.Menşe Ülke Etkisi ile Etnosentrik Eğilim Düzeyi Arasındaki İlişsi................ 99

5.6.8. Araştırma Hipotezleri Kabul/Red Durumu........................................................... 102

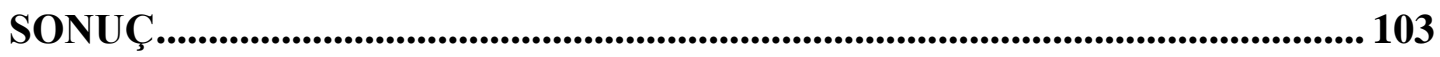

KAYNAKÇA ............................................................................................................................. 109 


\section{TABLOLAR LISTESİ}

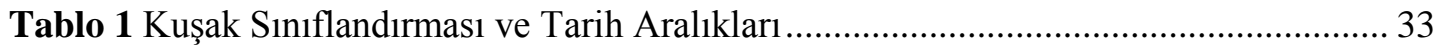

Tablo 2 Kuşakların Kişisel Özellikleri............................................................................... 34

Tablo 3 Y Kuşağının Atfedilen Yaş Aralıkları .................................................................. 38

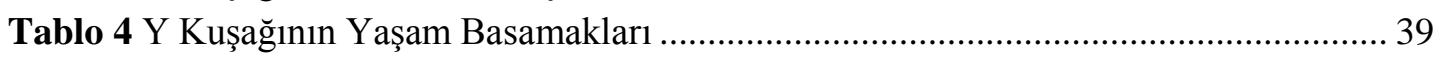

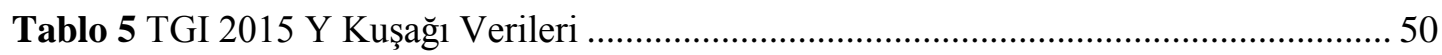

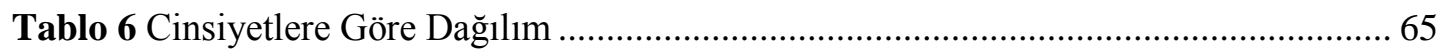

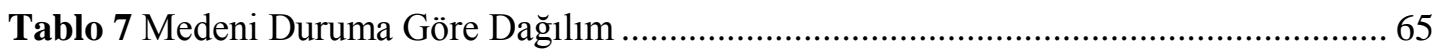

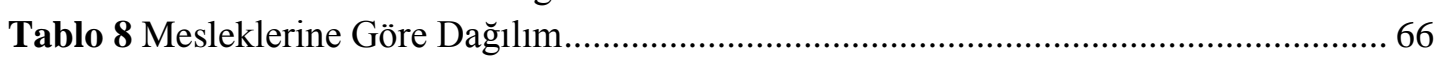

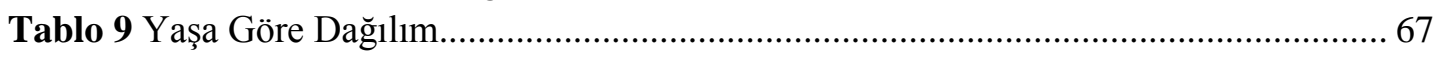

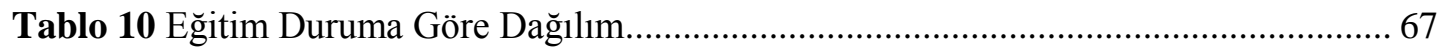

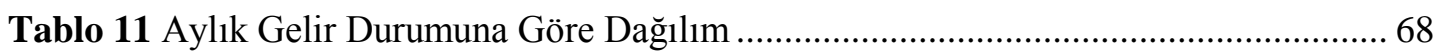

Tablo 12 Daha Önce Yurt Dışına Çıkma Durumuna Göre Dağılım ...................................... 68

Tablo 13 Yabancı Ürün Yargısı ve Satın Alma Niyet Ölçeğine İlişkin Soruların Dağıılımı . 69

Tablo 14 Ölçeğin Madde Sayısı ve Cronbach Alpha İç Tutarlılık Katsayısı ........................ 71

Tablo 15 Sınıflandırılmış Ürün Gruplarına İlişkin Soruların Dağılımı .................................. 72

Tablo 16 Ölçeğin Madde Sayısı ve Cronbach Alpha İç Tutarlılık Katsayısı ......................... 74

Tablo 17 Market Ürünleri Olarak Gruplandırılmış Soru Dağılımı ........................................ 74

Tablo 18 Mağaza Ürünleri Olarak Gruplandırılmış Soruların Dağılımı ............................... 76

Tablo 19 Pahalı ve Lüks Ürün Olarak Gruplandırılmış Soruların Dağılımı .......................... 77

Tablo 20 Etnosentrik CESTCALE Ölçeğine İlişkin Soruların Dağılımı ............................... 79

Tablo 21 Y Kuşağının Etnosentrik Eğilim Düzeylerine Göre Dağılımı ............................... 82

Tablo 22 Ölçeğin Madde Sayısı ve Cronbach Alpha İç Tutarlılık Katsayısı ......................... 82

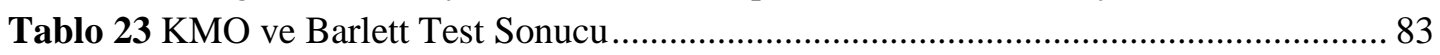

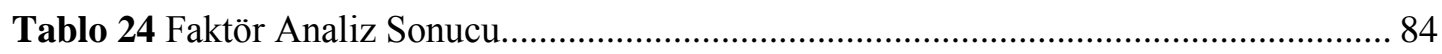

Tablo 25 Cinsiyete Göre Etnosentrik Eğilim Düzeylerinin Değerlendirilmesi..................... 87

Tablo 26 Medeni Duruma Göre Etnosentrik Eğilim Düzeylerinin Değerlendirilmesi........... 88

Tablo 27 Yurt Dışına Çıkma Durumuna Göre Etnosentrik Eğilimlerinin Değerlendirilmesi89

Tablo 28 Yaşa Göre Etnosentrik Eğilim Düzeyleri Değerlendirilmesi.................................. 90

Tablo 29 Eğitim Durumuna Göre Etnosentrik Eğilim Düzeylerinin Değerlendirilmesi ....... 91

Tablo 30 Meslek Gruplarına Göre Etnosentrik Eğilim Düzeylerinin Değerlendirilmesi...... 92

Tablo 31 Aylık Gelir Durumlarına Göre Etnosentrik Eğilim Düzeylerinin Değerlendirilmesi

Tablo 32 Etnosentrik Eğilim Düzeylerine Göre Ürün Yarg1sı ve Satın Alma Niyet

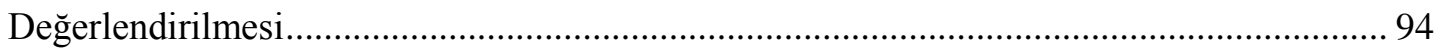

Tablo 33 Etnosentrik Eğilim Düzeylerine Göre Market Ürünleri Değerlendirilmesi ........... 95

Tablo 34 Etnosentrik Eğilim Düzeylerine Göre Mağaza Değerlendirilmesi ......................... 96

Tablo 35 Etnosentrik Eğilim Düzeylerine Göre Pahalı ve Lüks Ürün Değerlendirilmesi .... 97

Tablo 36 Menşe Ülke Etkisi Önerme 1'e Göre Ürün Yargısı ve Satın Alma Niyeti

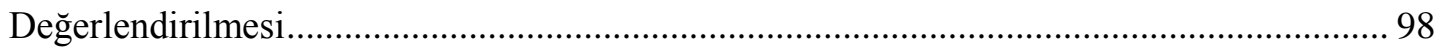

Tablo 37 Menşe Ülke Etkisi Önerme 2'ye Göre Ürün Yargısı ve Satın Alma Niyeti

Değerlendirilmesi. 99 
Tablo 38 Menşe Ülke Etkisi Önerme 1'e Göre Etnosentrik Eğilim Düzeyleri Değerlendirilmesi. 100

Tablo 39 Menşe Ülke Etkisi Önerme 2'ye Göre Etnosentrik Eğilim Düzeyleri

Değerlendirilmesi. 


\section{GİRIŞ}

Teknolojinin hızlı bir şekilde ilerlemesi ve iletişimin gün geçtikçe yaygınlaşması küreselleşme kavramını farklı boyutlara taşıyarak uluslararası rekabetin çok yoğun yaşanmasına sebebiyet vermektedir. Günümüzde dünyanın bir ucundan diğer ucuna üretilen her ürüne hızlı ve kolay ulaşma imkanı tanınmıştır. Tüketicilerin istek ve ihtiyaçlarını karşılayarak onları tatmin etmek, firmalar açısından güç bir hal almaktadır ve bu doğrultuda kültürler arası çalışmalar da artmaktadır.

Küreselleşmenin meydana getirdiği farklılıklar insanların yaşam tarzlarında, firmaların ve ülkelerin gelişimlerinde etki göstermektedir. Ulusal sınırların ortadan kalkması ile birlikte firmalar ticarette özgürleşmektedir. Birçok firma farklı ülkelerde farklı yatırımlar yapmaktadır. Dış pazarda gerçekleştirilen faaliyetlerde yaşanan artış da küreselleşmenin yayılma hızına etki etmektedir. Dış pazara açılma, firmalara firsat sunmakla birlikte bazı tehditler de içerebilmektedir.

Uluslararası sınırların ortadan kalkması ile firmaların ürün dağıtım yerleri artmakta, tüketicilerin de ürün yelpazesi genişlemektedir. Bu durum beraberinde ithal ürün kullanımının yerli üretim ve ülke istihdamı üzerinde zararlı olabileceği endişelerini getirmektedir. Ulusal sınırların ötesinde faaliyet gösteren firmaların başarılı olabilmeleri için hedef pazarda yer alan tüketicilerin kültürel ögelerine ve değer yargılarına önem vererek hassasiyet göstermeleri gerekmektedir. Çünkü tüketiciler farklı ülke ürünlerine karşı ön yargı ile yaklaşıp, olumlu veya olumsuz duygular besleyebilmektelerdir. Rekabetin günden güne artması, uluslararası pazarda faaliyet gösteren firmaların mevcut pazardaki konumlarını koruyabilme durumunu ciddi anlamda etkilemektedir. İşte bu noktada "tüketici etnosentrizmi" dediğimiz kavram devreye girmektedir. Firmalar yabancı pazarda başarılı olabilmeleri ve rekabet avantajı sağlayabilmeleri için hedef pazardaki tüketicilerin yabancı ürünlere karşı ön yargılarını belirleyen etnosentrik eğilimlerini ölçerek gerekli önlemler almaları ve buna uygun pazarlama stratejileri geliştirmeleri gerekmektedir. Etnosentrizm; kişinin kendi kültürünü diğer kültürlere kıyasla daha üstün gördüğü bir eğilim olarak ifade edilmektedir. Bu eğilimde olan kişiler, diğer kültürleri değerlendirirken kendi grubunun veya kültürünün standartlarını referans 
noktası olarak kabul etmektedir (Özçelik ve Torlak, 2011: 365). Tüketici etnosentrizmi dediğimiz kavram ise yabancı ürün kullanımının ahlaki açıdan uygun olup olmadığını tartışmakta olup tüketicilerin yabancı ürün yerine yerli ürünü tercih etme eğilimi olarak ifade edilebilir. Etnosentirk eğilim duygusu yüksek tüketicilerin, ekonomik açıdan ülkeye ve yerli iş gücüne zarar vereceği aynı zamanda işsizlik yaşatacağı düşüncesi ile ahlaki açıdan ise yabancı ürünler almanın milliyetçilik, vatanseverlik duygularıyla çeliştiğini; milletini ve ülkesini seven bireylerin mükemmel olan yerli ürünleri satın almalarının gerekliliğini ileri sürmektedir (Sharma vd., 1995).

$\mathrm{Bu}$ çalışmada tüketici olarak $\mathrm{Y}$ kuşağı ele alınmıştır bunun sebebi ise teknolojiyi çok iyi kullanan, pazarda harcama gücü bakımından önemli bir yere sahip olan bu kuşak üyelerinin büyük bir tüketici grubunu oluşturmasıdır. Yapılan çalışmalar neticesinde Y kuşağının zor bir tüketici grubunu oluşturduğunu ve bu kuşak ile birlikte pazar alanlarında ciddi anlamda farklılıkların gözlemleneceği belirtilmektedir. Firmalar tarafından Y kuşağının satın alma davranışlarının incelenmesi, istek ve ihtiyaçlarının analiz edilmesi, hangi ürünü hangi koşulda tükettiklerinin öğrenilmesi, bunlara uygun pazarlama stratejilerinin geliştirilmesi aynı pazarda aktif rol alan bir diğer firma ile arasında rekabet avantajı sağlayacak veya mevcut durumunu korumasina yardımcı olacaktır.

$\mathrm{Bu}$ araştırmada amaç $\mathrm{Y}$ kuşağı üyelerinin yerli ve yabancı ürünlere karşı etnosentrik eğilim düzeylerini düşük, orta ve yüksek şeklinde belirleyerek market, mağaza ve pahalı - lüks olarak kategorize edilmiş ürünlere karşı tutum ve davranışlarını inceleyip etnosetntrizm ile ilişkisine bakmaktır. Ayrıca Y kuşağın demografik özellikleri ile etnosentrik eğilimlerine göre satın alma davranışları arasındaki ilişkiyi incelemektir.

Çalışmanın birinci bölümü genel olarak etnosentrizm kavramı, etnosentrizm eğilimine sahip olan tüketicilerin özellikleri, tüketici etnosentrizmi ve bu olgunun işletme ve pazarlama açısından önemi incelenmiştir. Bu incelemeler yapılırken konu genel çerçevesine bağlı olarak tüketici etnosentrizminin pazarlamanın 4P'si olarak adlandırılan ürün, fiyat, tutundurma ve dağıtım üzerindeki etkileri, tüketici etnosentrizmini etkileyen faktörlerin neler olduğu incelenmiştir. İncelemelerde 
faktörler; demografik, sosyo psikolojik, ekonomik ve politik sınıfları altında irdelenmiştir. Çalışmanın birinci bölümünün sonlarında tüketici etnosentrizminin ülke menşe ile ilişkisine değinilmiştir ayrıca bu bağlamda bu ilişkilerin ve etkilerin ölçümünde kullanılan Cetscale ölçeği anlatılmıştır.

Çalışmanın ikinci bölümü araştırma konusunu oluşturan $\mathrm{Y}$ kuşağ1 çerçevesinde oluşturulmuştur. Öncelikli olarak kuşak kavramının tanımlarının incelenmesi, ayrıntılı bir şekilde bu kavramın açıklanması, kuşakların sınıflandırmalarının ve tarih aralıklarının anlatılması, sınıflandırma yapılan kuşakların kişisel özelliklerinin anlatılması ile birlikte kavrama açıklık getirilmiştir. Çalışmanın analiz kısmına geçiş aşamasını oluşturan ikinci bölümde kuşak sınıflandırmaların tamamına değinilmiştir fakat genel olarak X,Y ve Z kuşakları, özelinde de Y kuşağının özellikleri, tüketim alışkanlıkları ve bu kuşağın pazarlamada ki önemi anlatılmıştır.

Çalışmanın üçüncü bölümü istatistiki araştırmaların ve sonuçlarının ayrıntılı olarak incelendiği son bölümdür. Bu bölümde ortaya konulan araştırmalar ve veriler Afyonkarahisar ilinde yaşayan, 1980 ile 2000 yılları arasında doğan Y kuşağı üyelerine uygulanan anketlerden oluşmaktadır ve 500 kişiye uygulanmıştır. Anket sorularında 4 bölüm yer almaktadır ve 5'li likert ölçeği kullanılarak oluşturulmuştur. 1. bölümde katılımcıların demografik özelliklerine ilişkin sorular yer almaktadır. 2 . bölüm; 1998 yılında Klein ve Ettenson çalışmasında kullanılan yerli ve yabancı ürünlere karşı ürün yargı ve satın alma niyetini ölçen sorulardan oluşmaktadır ayrıca menşe ülke etkisi çalışılan birçok araştırmada yer alan katılımcıların bir ürünü almadan önce ürün ile ilgili bilgi edinmek, hangi ülkede üretildiğini öğrenmek amacı ile etiketine bakma sıklığını ölçen sorulardan oluşmaktadır. 3. bölüm; market ürünleri (gıda, temizlik, kozmetik, kişisel bakım) daha çok günlük hayatta kullanılan kolayca satın alınabilen, mağaza ürünleri (giyim, ayakkabı, aksesuar, çanta, beyaz eşya, ev elektroniği, mobilya küçük ev aletleri, oyun ve eğlence setleri) daha çok satın alma sırasında düşündüren beğenmeli ürünler, pahalı ve lüks ürünler (otomobil, ev, pahalı elektronik ürünler, pahalı mobilyalar, sanatsal ürünler, mücevher, koleksiyon ürünleri) daha çok satın almadan önce üzerinde uzun süre düşünülen kolayca erişim sağlanamayan lüks ürünlerden oluşmaktadır. Katılımcıların yerli/yabancı ürünlere karşı tutum ve davranışları, kategorize edilen ürün grupları 
için değerlendirilmesi istenmiştir. $\mathrm{Bu}$ bölüm (Ar1, 2007, Özmen, 2004) çalışmalarından uyarlanmış sorulardan oluşmaktadır. Anketin son bölümünde ise katılımcıların etnosentrik eğilim düzeylerini belirlemek amacı ile güvenilirliği ve geçerliliği test edilmiş Tüketici Etnosentrik Eğilim Ölçeği “CETSCALE (Consumer Ethnocentric Tendency Scale)" kullanılmıştır. 


\section{BIIRINCİ BÖLÜM}

\section{ETNOSENTRIZM}

\section{ETNOSENTRIZM KAVRAMI}

Bir toplum veya grup içerisinde yer alan kişiler yaşantı olarak birbirleri ile kültür, değer, inanç, norm, dil vb. bakımından yakınlık göstermektedir. Gösterdikleri bu yakınlık ile kişiler kendilerini toplum veya bir gruba ait hissetmektedir. Kişinin kendini bir toplum veya gruba ait hissetmesi anlamında olan "aidiyet" duygusu; aynı toplulukta yaşayan bireylerin hayatı anlamlandırmaları için bir zemin oluşturmakta ve kişilere bir kimlik kazandırmaktadır. Kişiler kazandıkları bu kimlik sayesinde kendini ifade ederek dünyayı daha açıklanabilir, güvenilebilir ve tanımlanabilir duruma getirmektedir. Aidiyet duygusu, toplumda yaşayan bireylerin ilişkilerini biçimlendirmesinde çok önemli bir olgudur. Etnosentrizmin diğer bir ifade şekliyle kültür taassubunun kökenlerini, aidiyet olgusunda aramak muhtemeldir. Kişi ait olduğu grup ve diğer gruplar olarak kendisini konumlandırarak bir biz ve diğeri olgularını meydana getirip onu yaşar, korur ve geliştirir (Özbek, 2005: 1-2).

İlk olarak Sosyolog William Graham Sumner tarafından literatüre kazandirılan; Yunancada "irk-millet" anlamına gelen "ethnos" ve merkez anlamında olan "kentron" kelimelerinin birleşmesi ile ortaya çıkan, İngilizcede "Ethnocentrism" şeklinde kullanılan, Türkçede ise "biz-merkezcilik", "ırk-merkezcilik" veya "etnosentrizm" kelimeleri ile belirtilen etnosentrizm kavramı; kişinin kendi kültürünü diğer kültürlere kıyasla daha üstün gördüğü bir eğilim olarak ifade edilmektedir. $\mathrm{Bu}$ eğilimde olan kişiler, diğer kültürleri değerlendirirken kendi grubunun veya kültürünün standartlarını referans noktası olarak kabul etmektedir (Özçelik ve Torlak, 2011: 365).

Etnosentrik eğilimleri olan bireyler kendi grubunu evrenin merkezi olarak görmekte, başka sosyal grupları ise ait olduğu kendi grubunun perspektifinde yorumlamaktadır. Kültürel değerleri kendi gruplarına benzer olanları üstün tutup körü körüne kabul ederken kültürel açıdan farklı olan etnik gruplardaki kişileri ise hor görüp reddeden insanlar için evrensel bir eğilimi ifade etmektedir (Shimp ve Sharma, 1987: 280). Bu yaklaşıma göre kişilerin kendi grup veya kültürünün değer, 
inanç, tutum ve sembolleri gurur kaynağı niteliğindeyken diğer grupların değer, inanç, tutum ve sembolleri önem arz etmemektedir (Elibol, 2013: 49). Etnosentrizim, gruplar arasındaki farkı ortaya çıkararak ya da ayırt ederek kendi grubunun ekonomik, politik ve sosyal menfaatleri doğrultusunda olayları algılamaktadır. Ayrıca kendi grup kültürlerinin hayatta kalmasını sağlamak amacıyla grubun dayanışmasını, uygunluğunu, işbirliğini, sadakatini ve etkinliğini arttırmaktadır (Sharma vd., 1995:27). Gruplaşma dediğimiz faktör, zaman içinde bireyler arasında etkileşimin artması ve nispeten devamlılık kazanmasıyla meydana gelmektedir. Grup; coğrafi bölge, kültür, ülke ya da etnik esaslar üzerine kurulmaktadır (Can ve Yiğit, 2017:103). Kültürel bir gruba dahil olma ise dil, din, aksan, fiziksel özellik vb. açıdan değerlendirilebilmektedir (Hammond ve Axelrod, 2006: 926).

Etnosentrizm başlangıçta iç grup ve dış grup kavramlarını ayırt etmek için tasarlanmış tamamen toplumsal bir kavramdır (He ve Wang, 2015). İç grup, kişinin kendini bağlı hissettiği, kültürel ve ahlaki değerleriyle övündüğü gruptur. Bu bir topluluk, etnik grup, alt kültür, bölge ya da ulus olabilir. Kişilerin kendini ait gördüğü ve bağlı hissettiği iç grubun dışında yer alan diğer grup ise dış grup olarak belirtilmektedir (Lantz ve Loeb, 1996: 374).

Etnosentrizm inançlara dayalı bir kavramdır. Grup içerisinde yer alan kişiler ile birlik ve beraberlik içerisinde çalışmak, onlara yardım etmek, ayrıcalık gösterip onlar ile övünmek; grup dışında yer alan kişilere ise güvenmeyip düşmanca tavırlar göstermektir (Balabanis vd., 2002: 10). Psikolojik bakış açısıyla yorumlanan başka bir açıklamada etnosentrizim; bir grubun varlığ 1 devam ettiği veya grup genişlediği sürece gruptaki kişilerin tamamına aynıymış gibi eşit davranmak, bazı üyelerin garip davranışlarını görmezlikten gelmek ve onlara karşı küçümseyici, nefret edici duygular beslememektir (Freud, 1955, akt.,Martinez vd., 2000: 1354).

Etnosentrizm, kültürün mihenk taşı olarak tüm kültürleri "alt, üst, iyi, kötü, doğru, yanlış" şeklinde değerlendirmektedir. Toplum içinde tamamı olmasa bile çoğu grup etnosentrik eğilim sergilemektedir (Caplow, 1964:213, akt., Yarangümelioğlu ve İşler ,2014:96).

Etnosentrizm kavramının olumlu ve olumsuz yönleri mevcuttur. Olumlu yönlerine bakıldığında etnosentrizm; kişi gruplarını bir arada tutarak onların 
dağılmasını ve kopmasını engelleyen, grup bağlılığını artıran bir kavram olduğu bilinir. Olumsuz yönlerine bakıldığında ise ayrımcılıkların oluşmasına sebebiyet veren, başkalarını küçük görüp dişlamaya yönelten tutum ve davranışlara sebep olduğu belirtilmektedir (Sökmen ve Tarakçoğlu, 2010: 28). Aynı zamanda sosyal ilişkiler üzerinde ciddi etkiler yaratmakta, farklı sosyal grup ve fertlerin toplum içinde sosyalleşmelerine engel olabilmektedir. Etnik farklılıklardan kaynaklanan güvensizlikler etnik çatışmaların temelini oluşturduğu için etnosentrik eğilimler olması gerekenden fazla olduğu takdirde sömürgecilik, 1rkçılık ve etnik temizlik gibi önemli toplumsal sorunlara neden olabilmektedir (Özbek, 2005: 2).

Tüm bu tanımlamalardan yola çıkarak etnosentrizm; kişinin dil, kültür, inanç, yaşam tarzı, değer ve tutumları bakımından kendine en yakın olan grubu benimseyip o gruba aitlik hissinin oluşmasıdır. Aynı zamanda grubun tüm özelliklerinin diğer gruplardan üstün olduğuna inanıp ön planda tutması ve diğer grupları değerlendirirken kendi grubunun özelliklerine göre değerlendirilmesi gerektiğini ifade eden kavram olarak söylenebilir.

\subsection{TÜKETİCİ ETNOSENTRİZMİ}

Küreselleşme ile birlikte tüketicilerin etrafı yerli ve yabancı birçok ürün ile çevrilmiştir. Ürünlerin çokluğu ister istemez tüketicilerin tercihini etkileyerek karar verme aşamasında ciddi anlamda çelişkiye düşürmektedir. Tüketiciler ithal ürün kullanımının ahlaki açıdan uygun olup olmadığı, ülke ekonomisine zarar verip vermediği düşünceleri ile sürüncemede kalmaktalardır. Bu durumlar neticesinde tüketici etnosentrizmin tüketici davranışıyla ilişkilendirilmesi söz konusu olabilmektedir.

İlk olarak sosyoloji alanında kullanılan etnosentrizm kavramı bazı araştırmacılar tarafından sadece sosyoloji ile sınırlandırılmayıp tüketici davranışı çalışmalarında da kullanılabileceği belirtilmektedir (Berkman ve Gilson, 1978). Etnosentrizmin tüketici davranışıyla ilişkilendirilmesi sonucu tüketici etnosentrizmi kavramı ortaya çıkmıştır. Bu kavram, tüketicilerin satın alma davranışından ziyade onların tüketim eğilimlerini veya yerli/yabancı ürünlere karşı hislerini yansıtan bir kavramdir (Sharma vd., 1995: 29). 
Tüketici etnosentrizmi 1987 yılında Shimp tarafından ortaya konulan çalışma ile pazarlama literatürüne kazandırılmıştır. Çalışmada A.B.D’li tüketicilerin yabancı ürün kullanmalarının ahlaki açıdan meşruluğu tartışılmakla birlikte ana temasını, tüketicilerin kendi ülkesinde üretilen bir ürünün mükemmel olduğu düşüncesine inanmaları oluşturmaktadır. Bunu temel alarak yerli ürünlerin satın alınmasını doğru bulma, yabancı ürünlerin satın alınmasının doğruluğunu sorgulamaktadır. Etnosentirk eğilim duygusu yüksek tüketicilerin ekonomik açıdan ülkeye ve yerli iş gücüne zarar vereceği aynı zamanda işsizlik yaşatacağı düşüncesi ile ahlaki açıdan ise yabancı ürünler almanın milliyetçilik, vatanseverlik duygularıyla çeliştiğini; milletini ve ülkesini seven bireylerin mükemmel olan yerli ürünleri satın almalarının gerekliliğini ileri sürmektedir (Sharma vd., 1995).

Fonksiyonel anlamda tüketici etnosentrizmi, bireyde aidiyet duygusunu oluşturup ona bir kimlik kazandırmakta, en önemlisi de ait olduğu grupta kabul edilebilen ve edilemeyen satın alma davranışlarının anlaşılmasını sağlamaktadır (Asil ve Kaya, 2013: 115). Bir başka ifadeyle tüketici açısından etnosentrizm, ürün ve markalara karşı tutum ve davranışları etkileyen bir kavramdır. Satın alma davranışında bulunan bireyin etnik, dini, coğrafi bölge gibi unsurları aidiyet duygusunun oluşumuna etki etmektedir. Kişi kendisini ait hissettiği toplumun ürünlerini, yabancı ürünlerden daha kaliteli olduğu düşüncesi ile satın alımlarını gerçekleştirmektedir (Küçükemiroğlu 1999: 471-472).

Tüketici etnosentrizmi kavramında değinilmesi gereken önemli iki nokta bulunmaktadır. Bu önemli noktalardan birincisi tüketici etnosentrizminin ürünü esas aldığı, ikincisi ise ilk kez William Graham Sumner tarafından sosyal anlamda kullanılan etnosentrizmin yalnızca ürün boyutu ile dar bir kalıba sokulmadığı bunun yanında politika, kültür gibi diğer birçok alanında esas alınarak genellenebileceğidir (Elibol, 2013:53). Tüketici etnosentizmin temeli ürüne dayandığı için tüketicilerin etnosentrik eğilim sergilemelerinde ürün kategorisinin büyük bir etkisi vardır. Bazı olası durumlarda ürünün özellikleri o ürünün tercihini etkileyebilmektedir. Örneğin; Rusya'da tüketim ürünlerinde yerli ürün kullanma eğilimi yüksek iken, dayanıklı tüketim ürünlerinde ise bu eğilimin gösterilmediği belirtilmiştir (Thelen vd., 2006). 
Etnosentrik eğilim gösteren tüketiciler kendi ülkelerinde üretilen ürünleri satın almak istemeyebilirler fakat satın alma davranışı sırasında içgüdüsel olarak o ürünleri seçmeyi kendilerine yükümlülük olarak hissetmektelerdir. Bu açıdan etnosentrizm kavramının tüketici etnosentrizmi boyutuna indirgenmesi gerekmektedir (Ha,1998: 9). Yabancı ürün fiyat açısından yerli üründen daha ucuz olsa bile etnosentrik eğilim gösteren tüketiciler tarafından satın alınmamaktadır. Çünkü etnosentrik eğilimleri yüksek olan tüketiciler yabancı ürün satın almayı gayri ahlaki bulmaktadır (Wang ve Chen, 2004: 392). Etnosentrik eğilime sahip olmayan tüketicilerin ise ürünün üretildiği yerin önemi bulunmamakta ve kişiler kendi değerlerine göre satın alma davranışı sergilemektedir. Aynı zamanda tüketicilerin fonksiyonel ve sembolik olarak yabancı ürünlerden umduğu değer düzeyinin, etnosentrizmin yabancı ürünlerin satın alınmasında oluşan olumsuz etkisini zayıflattığı ileri sürülmüştür (Wang ve Chen, 2004:391-392).

Tüketici etnosentrizminin etki ve derecesi kişiden kişiye değişiklik göstermektedir. Bu durumdan yola çıkılarak kişilerden oluşan kültürler açısından da tüketici etnosentrizmin etkisinin ve derecesinin değişebileceği sonucuna ulaşılmaktadır (Asil ve Kaya, 2013: 115). Polonya ve Rus tüketicilerinin karşılaştırılmalı olarak tüketici etnosentrik eğilimlerini inceleyen çalışmada, Polonyalı tüketicilerin Rus tüketicilere göre daha etnosentrik eğilime sahip oldukları gözlemlenmiştir (Good ve Hudleston, 1995: 41).

Etnosentrik eğilime sahip olan tüketicilerin özelliklerini aşağıdaki gibi sıralamak mümkündür (Shimp ve Sharma, 1987).

- $\quad$ Tüketici etnosentrizmi belirli bir ürüne yönelik tutum, niyet, davranış değil; tüm yabancı ürünlere yönelik tutarlı bir takım davranışları sergileyen genel bir eğilimdir.

- Tüketici etnosentrizmi, tüketicinin ülkeye gelen veya getirilen yabanc1 ürünlerin ülkeye zarar verebileceği kaygısından kaynaklanmaktadır.

- $\quad$ Tüketici etnosentrizmi, tüketicilerin yabancı ürün satın almasını gayri ahlaki bulup vatanseverliğe ters düştüğü ve ülke ekonomisine, iş gücüne zarar verebileceği düşüncesinden faydalanmaktadır. Dolayısıyla yerli ürünlerin kalitesi yabancı ürünler 
ile kıyaslandığında daha düşük olsa bile ahlaki açıdan uygunluğu sorgulandığı için tüketicilerin yerli ürün satın almasına neden olmaktadır.

- Tüketici etnosentrizmi, fiyat ve ürünlerin diğer özelliklerine göre talep edilenden daha az değişime neden olacak özellikler taşımaktadır.

- Tüketici etnosentrizmi, sosyal bir sistemde bireysel eğilimlerin toplamı olarak düşünülmesine rağmen yabancı ürünlere karşı bireysel önyargıyı ifade etmektedir.

- Tüketici etnosentrizmi, bireyin çocukluk döneminden başlayıp yetişkinlik dönemine kadar devam eden süreçteki aile, arkadaş, kişisel çevre, kitle iletişim araçları, fikir liderleri, din, aidiyet duygusu, etnik köken, 1rk gibi etkenlerden kaynaklanmaktadır.

- $\quad$ Tüketici etnosentrizmi, yabancı ürünlere karşı bilişsel, duygusal ve normatif yönelimleri içeren bir kavramdır. Bu kavram, ürün kalite ve değer algılamaları gibi nesne zeminli inanç ve tutumları, yabancı ürün satın alınıp alınmaması kararında doğru olanı seçmeye yönelik ahlaki zeminli inanç ve tutumları, bireysel menfaatlerine uygun olan ürünü seçmesi gibi tüketici davranışını anlamaya yönelik kişilik tabanlı inanç ve tutumları kapsamaktadır.

$\mathrm{Bu}$ özelliklere göre etnosentrik eğilime sahip tüketiciler yerli ürünleri; fiyat, kalite, performansı gibi özellikler açısından yabancı ürünlere nazaran daha düşük algılasa bile etnosentrik eğilim düzeyleri yüksek olduğu için yerli ürün tercih etmektedir. Ayrıca etnosentrik tüketiciler, yabancı ürün kullanılmasının ahlaki açıdan uygun bulmayıp ülke ekonomisine, iş gücüne zarar vereceği ve milliyetçi duygulardan uzaklaştıracağı düşüncesinden dolayı, yerli ürün tüketme eğilimi sergileyebilir. Uluslararası sınırların ortadan kalkması ile firmaların ürün dağıtım yerleri artmakla birlikte tüketicilerin de ürün yelpazesi genişlemektedir. Bu durum beraberinde ithal ürün kullanımının, yerli üretim ve ülke istihdamı üzerinde zararlı olabileceği endişelerini getirmektedir. Tüketicilerin etnosentrik eğilim göstermesi, yabancı ürün kullanımını minimize edip istihdamın artmasına ve yerli ürünlerin korunmasına fayda sağlayabilmektedir.

Etnosentrik satın alma davranışın en iyi örneği 1980'lere kadar ülkemizde kabul edilen "Yerli malı Türk'ün malı, her Türk bunu kullanmalı" sloganında kendini gösteren bir perspektif olduğu söylenebilir (Mutlu vd., 2011: 53). 


\subsection{TÜKETİCI ETNOSENTRIZM'IN İŞLETME VE PAZARLAMA AÇISINDAN ÖNEMİ}

Tüketicilerin yabancı ürünlere yönelik tutum, davranış ve düşünceleri uzun zamandır hem tüketici davranışının hem de uluslararası pazarlamanın dikkatini çekip ilgilendikleri bir konu olmuştur. Bu konuya dikkat çeken daha öncede bahsedildiği üzere etnosentrizmin tüketici davranışıyla ilişkilendirildiği “tüketici etnosentrizmi” kavramının pazarlama literatüründe öncüsü olan Terence A.Shimp oluşturmaktadır (Esen, 2011: 43).

Tüketici etnosentrizmin etkisiyle kişinin ürüne karşı kültürel ön yarg1, kalıplaşmış tutum ve davranışları sebebiyle yerli ürün satın alma eğilimi göstermesi pazarlamacıların dikkatini çeken bir unsur olduğu için bu eğilimi analiz etme ihtiyacı doğmuştur (Özden, 2017: 104). Tüketicilerin etnosentrik eğilimlerini ölçme amaçlı geliştirilen "Cetscale" ölçeğinin özellikle uluslararası pazarda faaliyet gösteren işletmeler tarafından büyük önem arz eden bir bilgi kaynağı olduğu ifade edilmektedir. Çünkü bu ölçekle elde edilen verilerin şirkete hedef pazar seçimi, bölümlendirmesi ve konumlandırması bakımından fayda sağlayacağı belirtilmektedir (Durvasula vd.,1997). Giderek artan küreselleşmenin etkisiyle uluslararası pazarlama stratejilerinde birçok etkenin daha dikkate alınarak hazırlanması gerekliliğini ortaya çıkmaktadır. Bu etkenlerden bir tanesi de tüketici etnosentrizmi kavramıdır. Özellikle uluslararası sınırların ötesinde faaliyete başlayacak olan işletmelerin tüketici etnosentrizmi etkilerini dikkate almadıkları takdirde başarısızlık ile karşı karşıya gelebilmektedir (Craig ve Douglas, 1996, akt, Ünal, 2011: 74). Bu noktadan hareketle tüketici etnosentrizmi, gelişmiş dünyanın karşısına çıkan kaçınılmaz bir kavramdır (Ar1 ve Madran, 2011: 18).

$\mathrm{Bu}$ açıklamalardan yola çıkarak yerli ve yabancı firmaların etnosentrik eğilimlerini kendi lehine çevirebilmeleri için hedef pazardaki tüketcilerin etnosentrik eğilimleri hakkında bilgi sahibi olmaları gerekmekte aynı zamanda edinilen bilgileri pazarlama karmasına uyarlayarak farklı pazarlama stratejileri geliştirmeleri firmalara avantaj sağlayacağını belirtmek yanlış olmayacaktır.

Pazarlama karması öğelerinin ve tüketici etnosentrizminin yabancı ürün satın alma davranışı üzerindeki etkisinin incelendiği bir çalışmada yerli ve yabancı ürün 
satın alma davranışının pazarlama karması elemanları üzerinde istatistikî olarak anlamlı etkisi olduğunu ifade edilmektedir (Herce,1994). Ürün, fiyat, tutundurma ve dağıtımdan oluşan pazarlama karmasının tüketici etnosetrizmi ile ilişkisi şu şekilde ifade edilmektedir:

Ürün: Tüketici etnosentrizmin temelini oluşturan kavram üründür. Çünkü tüketiciler ürünün etiketi veya ambalajı sayesinde o ürünün yerli mi yoksa yabancı bir ürün mü olduğunu, hangi ülkede üretildiğini bu sayede öğrenmektedir. Bazı araştırmacılara göre büyük bir kısmı yüksek etnosentrik eğilimlere sahip yerli ürün satın almak isteyen tüketicilerden oluşan uluslararası bir pazara girmek yabancı ürün satan firmalar için tehlikeli görülmektedir. Javalgi vd.,'ne (2005) göre bu durum tam tersi etnosentrik eğilimleri yükssek tüketicilerden oluşan pazardan kaçınılmamalı aksine bu durumu fırsata çevirmek için farklı pazarlama stratejileri geliştirilmeli şeklinde ifade edilmektedir. Tüketici etnosentrizmin olumsuz etkilerini ortadan kaldırmanın bir yolu olarak ürünün kökeni, ürün üzerine dikkat çekilmeyecek şekilde yerleştirilmesi ifade edilmiştir. Fakat bu şekildeki durumlarda da tüketiciler ürün üzerindeki "made-in" yazısını göremedikleri zaman ürünün yerli veya yabancı olduğuna dair marka isminden yola çıkarak tahminde bulunmaktadır. Bu durum da genelde yanlış değerlendirmelere sebep olmaktadır. Örneğin; ürünlerinin çoğu Japonya dışında üretilmesine rağmen Sony bir Japon ismi olduğu için tüketicilerde bu ürünün bir Japon markası oluğu ve Japonya'da üretilmiş olduğu algısı oluşmaktadır (akt, Ünal, 2011: 75).

Erzurum ilinde yapılan bir çalışmada, tüketicilerin içecek ve beyaz eşya sektöründeki etnosentrik eğilim düzeyleri bakımından anlamlı bir farklılık olduğu sonucuna varılmıştır (Yapraklı ve Keser, 2013: 415). İçecek sektöründeki tüketicilerin beyaz eşya sektöründeki tüketicilere oranla etnosentrik eğilim düzeylerinin daha fazla çıkması sonucu, tüketici etnosentrizmin üründen ürüne farklılık gösterebileceği kanısına varmak yanlış olmayacaktır. Amerika'da yapılan diğer bir incelemede, tüketicilerin elektronik ürün değerlendirmesinde etnosentrik eğilim göstermedikleri, araba ve giysi ürünlerinde değerlendirme yaparken ise etnosentrik eğilim gösterdikleri sonucuna ulaşılmıştır. 
Fiyat: Kanadalı ve Amerikalı tüketicilerin etnosentrik eğilimlerinin ölçüldüğü araştırmada etnosentrizm seviyeleri arttıkça fiyatın önemi azaldığı sonucuna varılmıştır. Tüketiciler için ürünün fiyatı yüksek bile olsa yerli ürün tercih etme eğiliminde oldukları; etnosentrik eğilimleri düşük olan tüketicilerde ise fiyat önemli bir faktör olduğu yerli ve yabancı ürün arasındaki tercihlerini fiyata dayandırarak hangi ürünün fiyatı uygunsa onu tercih etme eğiliminde oldukları sonucuna ulaşılmıştır (Lantz ve Loeb 1996: 376). Etnosentrik eğilimleri yüksek olan bireyler ekonomik ve ahlaki sebeplere dayanarak yerli ürünleri tercih ettiği birçok araştırmacı tarafindan ortaya konulmuştur. Bazen içgüdüsel olarak kişi kendi ülkesinin ürününü tercih etmek istemekte fakat bütçeleri onların bu tutumlarını engellemektedir. Yüksek etnosentrik eğilime sahip tüketicilerden oluşan pazara girerken tüketicilerin gelir durumları dikkate alınarak bölümlendirme yapılabilir ve değişik fiyatlama stratejileri geliştirilerek firmaların bu durumu kendi lehlerine dönüştürmeleri sağlanabilir (Ünal, 2011: 76).

Tutundurma: Firmalar etnosentrik eğilimin, yerli ürün satın alma niyetini etkilediği veya etkilemediği tüketicilere karşı aynı yaklaşımları benimsememeleri gerekmektedir. Dolayısıyla firmalar kendilerine uygun pazarlama stratejisi oluştururken başarılı olabilmeleri veya rekabetin arttığı bu zamanda tutunabilmeleri için tüketicilerin etnosentrik eğilimlerini göz önünde bulundurarak hitap edilen kitleye uygun stratejiler geliştirmelilerdir.

Cola Turka reklamındaki milliyetçi söylemlerin yerli ürün tercihi ile ilişkisini inceleyen çalışmada Türk tüketicilerinin büyük bir kısmının reklamları abartılı buldukları sonucuna varılmıştır. Türk tüketiciler, reklamlarda ürünün özellikleri ön plana çıkartılması yerine milliyetçilik ve vatanseverlik unsurlarına vurgu yapıldığını, bunun yanlış bir strateji olduğunu ve ürün denense bile beğenilmediğinde bağımlılık yaratmadığını belirtmektelerdir. Buradan da anlaşıldığı üzere, Cola Turka reklamlarında yerli ürüne dikkat çekmek isterken milli kimliğe pek uygun olmayan yöntemler seçilmesi yani yerli ürünün tutundurma çabasında yanlış stratejinin kullanılması hedef pazarda varmak istenilen noktaya ulaşılmasını engelleyebilmektedir (Dedeoğlu vd., 2005). 
Dağıtım: İşletmelerin amacı doğru zamanda doğru yerde doğru hedef kitlesine doğru hizmeti sunabilmektir. Ülkelerde yaşanan ekonomik ve politik olaylar ister istemez vatanseverlik duygularıyla hareket eden tüketicileri aynı zamanda o pazara giren işletmeleri etkilemektedir. Örneğin; İsrail'in Gazze'ye saldırı düzenlemesinden sonra vatandaşlar tarafından İsrail ürünleri boykot edilmiştir. Bunun yanında belediye kurumları da bu boykota destek vermiş, birçok sosyal tesislerde İsrail ürünlerinin kullanılmayacağı duyurusunda bulunmuştur. Bu durum etnosentrik eğilimin, pazarlama karması elemanını olumsuz yönde etkileyen bir örnek olduğu düşünülmektedir. Çünkü boykot edilen işletmeler önemli bir dağıtım alanından mahrum edilmiştir. İşletmeler, tüketici etnosentrik eğilimlerin dağıtım elemanına yarattığı olumsuz etkilerden kaçınmak için farklı stratejilere geliştirmeleri onlara fayda sağlayacaktır (Özden, 2017: 109). Tüketici etnosentrizmin yüksek olduğu pazarda, etnosentrizmin olumsuz etkilerinden kaçınmak isteyen yabancı firmalar daha çok telefonla veya internet aracılığıyla satışa yönelebilirler. (Ünal, 2011: 77). Bu durumda tüketicilerin sadece ürün odaklı olması sağlanabilir dolayısıyla yerli veya yabancı ürün sorgulamasından biraz uzaklaşılabilir şeklinde yorum yapilabilir.

Küreselleşmenin etkisi, teknolojinin gelişmesi ve tüketicilerin ürün yelpazesinin genişlemesi ile giderek büyüyen bir pazar meydana gelmektedir. Böyle bir dönemde hem yerel işletmelerin hem de sınırlar ötesine ulaşabilen uluslararası işletmelerin pazarda etkin rol almaları bir başka ifadeyle tutunabilmeleri için hedef pazardaki yabancı ürün kullanımını reddeden tüketicilerin etnosentrik eğilimleri hakkında bilgi sahibi olmaları ve ona uygun pazarlama stratejileri geliştirmeleri tüketici etnosentrizmini avantaja çevirecektir.

\subsection{TÜKETİCI ETNOSENTRIZMINİ ETKİLEYEN FAKTÖRLER}

Bireylerin satın alma davranışlarında etnosentrik eğilimleri oluşmasına veya artmasına neden olan çeşitli faktörler olduğu söylenebilir. Bu faktörler tüketici etnosentrizmini tek başına tetikleyebildiği gibi genellikle birbirine bağıntılı olarak oluşmasını ve gelişmesini de sağlayabilmektedir. Bireylerde demografik bir faktör olan yaş büyüdükçe sosyal psikoloji veya politik bir faktör olan muhafazakârlık da 
yükselmekte bu durum da tüketici etnosentrizmini yükselten bir durum oluşturabilmektedir (Sharma vd.,1995: 29).

Pazarlama literatürüne Shimp tarafından kazandırılan tüketici etnosentrizmi olgusunun hangi faktörlerden neye göre etkilendiği, bunun sonucu tüketicilerin nasıl bir davranış sergilediği ile ilgili birçok araştırma yapılmıştır. Tüketicilerin etnosentrik eğilim derecesinin artması veya azalması durumuna etki eden bazı faktörler bulunmaktadır. Bu faktörler; demografik, sosyo-psikolojik, ekonomik ve politik faktörler başlıkları altında sınıflandırılarak açıklanmaktadır.

\subsubsection{Demografik faktörler}

Tüketicilerin yabancı ürünlere yönelik tutum ve davranışının demografik özellikler ile ilişkilendirildiği çok sayıda çalışma yapılmıştır ve yapılan çalışmalara bakıldığında bazı farklılıkların olduğu ortaya çıkmıştır. Bireylerin cinsiyeti, yaşı, eğitim seviyesi, gelir durumu vs. farklılaştıkça etnosentrizmin derecesi veya etnosentrizme dayalı tutum ve davranışları da farklılaşabilmektedir. Bazı araştırmalara göre yaş ve tüketici etnosentrizmi arasında olumlu bir ilişki olduğu sonucuna varılarak, yaş arttıkça buna paralel olarak ernosentrik eğilimlerinde arttığı gözlemlenmiştir (Asil ve Kaya, 2013: 128). (Josiassen vd.,2011: 630), yaşl1 tüketicilerin genç tüketicilere kıyasla tüketim konusunda daha etnosentrik eğilim gösterdiğini belirtmektedir. Bir başka araştırmada, yaşlı tüketicilerin yerel dil kullanımına yatkın olup daha yüksek etnosentrik eğilim sergiledikleri belirtilmektedir (Cleveland vd.,2009: 61).

Cinsiyet ile etnosentrizim arasındaki ilişkiye bakıldığında kadınların erkeklere kıyasla daha etnosentrik eğilime sahip olduğu sonucunu ortaya konmaktadır (Sharma vd., 1995: 29). Çünkü daha önce yapılan araştırmalar incelendiğinde kadınların daha muhafazakâr, daha vatansever ayrıca bir gruba bağlılığı ve uyumu daha yüksek olduğu belirtilmektedir (Balıkçığlu, 2008: 156). Bununla birlikte yapılan bazı araştırmalar da ise bu durumun tam tersi olduğu kanısına varılmıştır. Örneğin; Good ve Huddleston'un Rusya'da 1995 yılında, Caruana'ın Malta'da 1996 yılında, Balabanis vd., Çek Cumhuriyeti'nde 2001 yılında yapmış oldukları çalışmalarda tüketici etnosentrizm ile cinsiyet arasında anlamlı bir 
ilişki bulmamışlardır. Yapılan araştırmalar genellikle bu ilişkinin ülkeden ülkeye, kültürden kültüre veya bölgeden bölgeye farklılık gösterdiğine yöneliktir.

Cinsiyet ile benzer şekilde eğitim durumu ve etnosentrik eğilim arasındaki ilişkiye dair farklı araştırmalarda farklı sonuçlar ortaya çıkmıştır. Genellikle demografik faktörler ile tüketici etnosentrizmi arasındaki ilişkiyi ele alan çalışmalarda kişilerin eğitim düzeyi yükseldikçe etnosentrik duygularının azaldığı sonucuna varılmıştır (Sharma vd., 1995:29). Dolayısıyla eğitim durumun yükselmesi ile kişilerin hayat standartlarını değişmesi, daha az tutucu hale gelmesi ve yabancı ürünlere karşı ön yargılarının azalması, bu duruma etki ettiği söylenebilir. Bazı araştırmacilara göre ise bu durumun tam tersi olduğu, eğitim durumu ile tüketici etnosetrizm arasında ilişki olmadığı sonucuna ulaşılmıştır (Dedeoğlu vd., 2005). Türkiye Isparta ilinde tüketicilerin entrosentrizmi ve menşe ülke etkisinin satın alma kararlarındaki rolünü konu alan bir çalışmada, eğitim seviyesinin yükselmesi ile etnosentrik eğilim derecesinin de yükseldiği sonucuna varılmıştır (İşler, 2013: 109).

Eğitim ile birlikte gelir durumu da kişinin yaşam tarzını, hayat standartlarını ve satın alma davranışını etkileyebilmektedir. Gelir durumu ile etnosentrik eğilimler arasındaki ilişkiye bakıldığında diğer demografik özellikler ile etnosentrizim arasındaki ilişkiye benzer olarak farklı araştırmalara göre farklı sonuçlar ortaya çıkmıştır. Çoğu çalışmada gelir düzeyi arttıkça etnosentrik tüketici eğilimlerinin zayıflayacağı sonucuna varılmıştır. Bir kişinin gelir durumu arttığında, yurtdışı seyahat sıklığı da artmaktadır buna bağlı olarak daha fazla ürün deneme şansına ulaşmakta ve vatanseverlik duyguları yerine ürünleri kalitesine göre değerlendirme davranışı göstermektedir (Sharma vd.,1995: 29). Supphelen ve Rittenburg 2001 yılında yaptığı çalışmalarda bu duruma benzer sonuçlara ulaşmıştır.

Balabanis vd. (2001: 161) tüketici etnosentrizmi ile ilgili yapmış olduğu bir çalışmada yaş olarak büyük ve eğitim olarak düşük eğitime sahip olan bayanların daha fazla milletini sever olduğunu ve daha fazla muhafazakâr olduğunu, yüksek gelir ve iyi bir eğitime sahip erkeklerin ise etnosentrik eğilimleri düşük olduğunu ifade etmektedir. Bununla birlikte gelirin artması ile daha çok seyahat etme ve daha çok ürün deneme imkânı olduğu, gelir ile seyahat etme sıklığını birbirine paralel olduğunu belirtmektedir. Dolayısıyla gelirin artması ile etnosentrik eğilimlerin 
azalması ve yabancı ürün tercih etmeye açık olduğu bir durumun ortaya çıkması söz konusudur.

\subsubsection{Sosyal Psikolojik Faktörler}

Sosyal psikolojik faktörler kişilerin kendisinin veya içerisinde bulunduğu grubun diğer gruba karşı olan tutum ve davranışları ile alakalı olduğu söylenebilir. $\mathrm{Bu}$ faktörler; milliyetçilik, vatanseverlik, muhafazakârlık, düşmanlık, bireyciliktoplumculuk, kültürel benzerlik şeklinde sıralanmaktadır (Shankarmahesh, 2006).

Etnosentrizm sosyal psikolojik bir kavram olduğu için diğer birçok sosyal psikolojik kavramlarla da iç içedir. Bireylerin etnosentrik eğilimlerinden hem etkilenebilmekte hem de etkileyebilmektedir. $\mathrm{Bu}$ kavramların birçoğu tüketici etnosentrizmini etkileyen birer faktör olabilmektedir. Çeşitli sosyal-psikolojik faktörler bireylerin yerli ürünlere ve markalara yönelik eğilimlerinin oluşmasını veya yükselip azalmasını etkileyebilmektedir. Bu durumun özellikle bireyin kendisinin ve sosyal psikolojik anlamda içerisinde bulunduğu grubun diğer gruplara karşı olan tutumları ile alakalı olduğu belirtilebilir.

\subsubsection{Milliyetçilik ve Vatanseverlik}

Milliyetçilik ve vatanseverlik kavramları çoğu zaman birbirinin yerine kullanılsa da anlam olarak birbirinden farklıdır. Vatanseverlik, kişinin kendi milletine karşı güçlü duygular besleyip fedakârlık yapacak kadar vatanını benimsemesi ve vatanına sadakat ile bağlı olmasıdır. Milliyetçilik ise kişinin diğer milletleri dışlayarak kendi ülkesini üstün ve baskın görmesi şeklinde ifade edilmektedir (Balabanis vd., 2001: 158). Milliyetçi bir bireyin aynı zamanda vatansever olduğu ama diğer ülkelere karşı önyargılı olduğu söylenebilir.

Çek Cumhuriyeti ve Türkiye üzerine yapılan bir çalışmada tüketici etnosentrizmin, vatanseverlik ve milliyetçilik arasındaki ilişkiye dair bulgular şu şekildedir: Türkiye de vatanseverliğin etnosentrizmi etkileyen en önemli unsur olduğu ve vatanseverlik derecesi arttıkça tüketici etnosentrizminin de $\operatorname{arttığ}$ gözlemlenmiştir. Çeklerde ise tüketici etnosentrizmine neden olan en önemli faktör olarak milliyetçilik olduğu sonucuna varılmıştır (Balabanis vd., 2001: 169). Bu 
durumdan yola çıkarak yoğun milliyetçilik ve vatanseverlik duygularına sahip kişilerin kendi ülkesinin ekonomi ve iş gücünü düşünerek yerli ürün tercih etmeleri dolayısıyla yüksek etnosentrik eğilim göstermeleri beklenebilir.

Sharma, Shimp ve Shin tarafından 1995 yılında Koreli tüketiciler için yapılan araştırmada vatanseverlik ve tüketici etnosentrizmi arasında pozitif bir ilişki olduğu fakat bu durumun etkileri ülkeden ülkeye ve kültürden kültüre farklılık gösterebileceği sonucuna varılmıştır (İşler, 2013: 96).

Amerikan vatandaşlarına yapılan bir diğer araştırmada da vatanseverlik ve tüketici etnosentrizmi arasında pozitif bir ilişki olduğu, kendilerini vatansever olarak nitelendiren tüketicilerin tüketici etnosentrizmi eğilimlerinin yüksek olduğu sonucuna varılmıştır (Klein ve Ettenson, 1999: 15). Genel olarak ülkesini seven ve yerli ekonomisine zarar vermek istemeyen tüketicilerin yerli ürün tercih ettiği dolayısıyla bu kişileri milliyetçilik ve vatanseverlik duygularını yoğun yaşadığı bu sebeple yüksek etnosentrik eğilimlere sahip olduğu söylenebilir.

\subsubsection{Muhafazakârlık}

Muhafazakârlık, kişinin sahip olduğu değerler sisteminin aile, toplumsal hayat ve toplumun diğer üyeleri ile kurulan ilişkilerde gelenekselliği tercih etme şeklidir. Aynı zamanda “yeni” karşısında, “doğal” kabul edilen, “var olan” üzerinden ifade edilen sosyo - politik bir tutumdur (Topçu, 2014: 47).

Muhafazakârlık ve tüketici etnosentrizmi arasındaki ilişki ilk olarak Shimp ve Sharma tarafından 1987 yılında ifade edilmiştir. Muhafazakârlık; gelenekleri, sosyal kuramlar ile destekleyip onlara saygı göstermek ve zaman zaman isteksizce değişiklikleri yavaş yavaş kabul etme eğilimidir. Genel olarak muhafazakar insanlar yabancı ürünleri olumsuz ve yerli ürünleri olumlu değerlendirdikleri için etnosentrizmi eğilimleri yüksek kişilerdir (Sharma vd., 1995: 35). Aynı zamanda muhafazakar olan kişiler, yabancı ürünleri mevcut kültür ve değerlerine tehdit niteliğinde görmekte ve tüketici etnosentrizm ile muhafazakarlık arasında pozitif bir ilişki olduğunu belirtilmektedir ( Balabanis vd., 2001). 
Sonuç olarak muhafazakâr kişilerin gelenekselliği önemsemeleri ve ön planda tutmaları, onların alışkanlıklarından kolay vazgeçemeyeceği ve buna bağlı olarak etnosentrik eğilim sergileyeceği söylenebilir.

\subsubsection{Düşmanlık}

Tüketici düşmanlığı, ülkeler arasında geçmişte yaşanan politik, ekonomik, askeri vs. problemlerin kalıntıları sebebiyle oluşan antipatik duyguların satın alma davranışlarını etkilemesidir (Klein ve Ettenson, 1998: 90).

Altıntaş ve Tokol tarafından 2007 yılında Avrupa orjinli ürünlere karşı Türk tüketicilerinin tutumlarına yönelik yabancı düşmanlığı, yabancılara karşı negatif tutumları ve muhafazakârlık kavramları incelenmişlerdir. Türk tüketiciler için tüketici etnosentrizmini etkileyen kavramlar arasında en büyük etki yabancı düşmanlığı olduğu sonucuna varılmıştır (Akın vd., 2009: 495).

Tüketici etnosentrizm ile düşmanlık arasındaki ilişki şu şekilde ifade edilmektedir; düşmanlık sadece aralarında sorunların yaşandığı belirli ülkelerin ürünlerini reddetmesi sonucu onlara karşı oluşan bir tepkidir. Tüketici etnosentrizmi ise bütün yabancı ürünleri reddetme eğilimi göstermektedir. Belirli bir ülkeye karşı düşmanlık duygusu yüksek tüketicilerin o ülkenin ürünlerine ilişkin algıdan değil, millet olarak sevmemelerinden kaynaklanmaktadır (Klein vd. 1998: 90-92). Yani etnosentrik eğilimleri düşük olan tüketicilerin yaşadıkları ekonomik, politik ve tarihi olaylar nedeniyle bazı ülkelere karşı düşmanlık duygusu besleyebilmekte ve bu durumu satın alma davranışlarına yansıtabilmektedir. Buradan hareketle düşmanlığın ürünlerin kalite değerlemesi üzerine değil, geçmişte yaşanan olayların etkisiyle belirli ülkelere karşı oluşan his şeklinde ifade edilebilir. Ayrıca tüketicinin etnosentrik duyguları düşük olsa bile düşmanlık hissi beslediği ülkenin ürünlerine karşı satın almama davranışı sergileyebilir. Kısacası düşmanlık hissi ürünün kalite değerlendirmesi ile ilgili olmayıp belirli ülkeler ile yaşanan bazı olaylar nedeniyle o ülkeye karşı oluşan hislerin tutum ve davranışlara yansıması sonucuna varılabilir.

Geçmişten günümüze birçok ülkede ekonomik veya siyasi sebeplerden dolayı düşmanlık olgusu oluştuğu ve bu olgunun kitle hareketine dönüştüğü örnekler yaşanmıştır. Irak Savaşı nedeniyle Amerikan mallarının dünyada çeşitli ülkelerde 
boykot edilmesi ve Amerikan kültürün sembolü olduğu düşünülen McDonald's restoranlarının tahrip edilmesi, Ermeni Yasa Tasarısı nedeniyle Türkiye'nin Fransız ürünlerini boykot etmesi bu duruma verilebilecek örneklerin birkaçını oluşturmaktadır (Özden, 2017: 82).

\subsubsection{Bireycilik ve Toplumculuk}

Bireycilik ve toplumculuk kavramı, bireylerin grup ile özdeşleşme seviyesi şeklinde ifade edilmektedir. Kimi toplumda bireyciliği ön plana çıkaran inanç ve değerler egemen iken kimi toplumda ise toplumculuğu ön plana çıkaran inanç ve değerler egemen olmaktadır. Genellikle bireyci kültürlerde "ben” düşüncesi hâkim olmakla beraber bireyler arasındaki ilişki zayıftır ve her birey kendi menfaatini düşünmektedir. Toplumcu kültürlerde ise "biz" düşüncesi hâkim olmakla beraber toplumu oluşturan bireyler arasındaki ilişki güçlüdür ve toplum menfaati ön planda tutulmaktadır. Eğer bir toplumda bireycilik veya toplumculuk inanç ve değerleri daha egemen ise birey veya grupların tutum ve davranışlarına yansıdığı ve farklı uygulamalara neden olduğu gözlemlenmiştir (Hofstede ve Bond, 1988). Bu durumdan hareketle bireycilik ve toplumculuğun etnosentrik eğilim ile ilişkisine bakıldığında toplumcu tüketicilerde toplumun çıkarları ön planda tutulduğu için etnosentrik eğilimlerinin daha yüksek olduğu belirtilebilir.

Toplumcu tüketiciler zorunlu olarak kendi ülkelerinde üretilen ürünleri tercih etmekte ve toplumculuk formu ülke düzeyinde vatanseverlik seviyesindedir (Yoo ve Donthu, 2005). Bu nedenle toplumcu tüketiciler yerli ürün alarak üyesi olduğu kültürü veya ülkeyi koruduğunu düşünmektedir (Triandis, vd., 1988). Yapılan birçok araştırma sonucunda toplumculuk ve etnosentrik eğilim arasında pozitif bir ilişki olduğu ortaya çıkmıştır. Bireyci kültürlerin ise kendi çıkarlarını toplumun çıkarlarından daha ön planda tutukları için düşük etnosentrik eğilimlere sahip oldukları söylenebilir. Fakat bazı araştırmacılar, bireycilik ve toplumculuk ile etnosentrik eğilimler arasındaki ilişkinin kültürden kültüre değişsebileceği sonucuna ulaşmışlardır (Özden, 2017: 77).

Tüm bunlardan hareketle, bireycilik ve toplumculuk olgusunu bir toplum veya kültürde bireysel değerler mi yoksa toplumsal değerler mi hâkim olduğuna yönelik kültürel değişken olduğu ifade edilebilir. Bireysellikte genellikle kişinin 
kendi menfaatini önemsediği diğer bireyler ile arasındaki ilişkinin zayıf olduğu yönünde kültürel bir değişken olduğunu belirtilebilir.

\subsubsection{Kültürel Benzerlik}

Etnosentrizm eğilimine sahip olan kişiler kendi kültürlerine benzeyen kültürleri, benzemeyen veya az benzeyen kültürlere göre daha üstün, daha iyi kabul etmekte ve o kültürlere karşı daha 1lımlı duygular beslemektedir. Kültürlerin veya grupların arasındaki zıtlıklar, farklılıklar arttıkça grupların arasındaki mesafe de artmakta ve buna bağlı olarak ilişkiler zayıflayabilmekte veya azalabilmektedir (Kızıltaş, 2014: 53).

Kültürel benzerliğin tüketici etnosentrizme etkisini inceleyen araştırmacılar tüketici etnosentrizmi ile kültürel benzerlik arasında pozitif bir ilişkinin olduğunu buna bağlı olarak da etnosentrik eğilimi yüksek olan tüketicinin ürünlere karşı tutum ve davranışlarında kültürel benzerliğin etkili olduğu sonucuna varmışlardır (Shankarmahesh, 2006).

Yeni Zellanda'da kültürel benzerlik ile tüketici etnosentrizm arasındaki ilişkiyi konu alan çalışmada etnosentrik eğilimleri yüksek tüketicilerin kendi ülkelerine yakın veya benzer tutum ve inançlara sahip ülkenin ürünlerine karşı daha olumlu tutumlar gösterdikleri belirtilmektedir (Watson ve Wright, 2000: 1158). Aynı şekilde başka bir araştırmada kültürel benzerlik ile etnosentrizm arasındaki ilişki incelendiğinde benzer sonuçlar elde edilmektedir. Yüksek etnosentrik eğilime sahip tüketicilerin kendi ülkesine veya kültürüne yakın ülkelerin ürünlerini tercih etme eğilimi sergilemektedir (Lantz ve Loeb, 1996: 374-378).

\subsubsection{Ekonomik Faktörler}

Tüketici etnosentrizmi, etnosentrizm kavramının ekonomik bir formudur. Tüketicilerin kendileri etkilenmedikleri halde ülke ekonomilerinin tehdit altında olduğunu düşünerek yüksek etnosentrik eğilim sergilemektedir (Sharma vd., 1995:27). Ekonomik faktörler arasında; ülkelerin gelişmişlik seviyesi, milli geliri ve gelir dağılımı gibi belirtiler yer almaktadır (Mutlu vd., 2011: 56). Tüketicilerin etnosentrik eğilimleri ekonomik olarak gelişmiş veya az gelişmiş ülkeler arasında, 
ürünlerin özellikleri veya tüketicilerin gelir durumu gibi sebeplerden değişiklik gösterebilmektedir.

Gelişmiş ülkeler kendi ürünlerini ithal ürünlere göre daha kaliteli ve üstün gördükleri için kendi ürünlerini tercih etme eğilimi sergilemektedir. Milliyetçilik, etnosentrizm ve yurtseverlik duyguları gelişmiş ülkelere göre daha yükssek olan az gelişmiş ülkelerde ise yabancı ürünlerin daha kaliteli olduğu ve statü kazandırdığı gibi gerekçeler ile gelişmiş ülkelerin ürünlerini tercih etmekte oldukları gözlemlenmiştir (Wang ve Chen, 2004: 398).

Varma 1998 yılında yapmış olduğu çalışmada Hindistanlı tüketicilerin yabancı ürünleri tercih etme eğilimi gösterip yabancı ürünlere karşı taleplerinin fazla olduğunu ortaya çıkarmıştır. Bu duruma ise aşağılık kompleksi, statü sembolü arayışı, batıyla olan ilişkilerin artması, tüketicilerin beklentilerinin değişmesi, gelirinin artması ve kültürel anlamda markalara açık olmaları sebebiyet vermektedir. Buna karşın Bawa (2004) ile Batra, vd., (2000), Hindistanlı tüketiciler üzerine yaptıkları bir araştırmada etnosentrik eğilimleri yüksek çıktığı yani yerli ürün tüketme eğiliminde oldukları ortaya konmuştur (Arı, 2007:25).

Fiyat olarak düşük ve az tanınmış ürünlere nazaran dünya çapında ünlü bir marka veya ürünün tercih edilme sebebi olarak şunlar belirtilmektedir: Gelişmekte olan ülke tüketicileri ünlü bir markayı yüksek kalitede ve prestijli algıladıkları için fiyatını da yüksek algılayabilmektedirler. Diğer bir neden ise düşük fiyatlı yerli ürüne daha kolay ulaşma imkanı olmasıdır (Lee vd., 2008: 165).

Genel olarak bakıldığında gelişmiş ülkelerdeki tüketiciler kendi ülkelerinde üretilen ürünleri her açıdan daha kaliteli hatta mükemmel buldukların için yerli ürün tercih etme eğilimlerinde bulunmaktadır. Az gelişmiş ülkelerde yaşayan tüketicilerin ise genel olarak gelişmiş ülkelere nazaran kendi ülke ürünlerini kalite olarak daha düşük görmekte bu yüzden yabancı ülke ürünü tercih etme eğilimi göstermektedir. Fakat bu durum yabancı ülke ürünlerin fiyatları, tüketicilerin gelir durumu ve ülke ekonomisine yardım etme ihtiyacı diğer bir ifadeyle etnosentrizmden etkilenmektedir. Tüketicilerde bu sebepler ağır bastığında kalite bakımından daha düşük olmasına rağmen tüketiciyi yerli ürüne teşvik etmektedir (Asil ve Kaya, 2013: 127). Dünyanın en gelişmiş ülkelerinden birisi olan Japonya, teknoloji alanında 
büyük çok uluslu bazı şirketlere ev sahipliği yapmaktadır. Ekonomik anlamda büyük bir güç haline gelen Japonya'da tüketiciler ithal ürün yerine kendi ülkelerinin ürünlerini tercih etme eğilimi sergilemektedir (Lee vd., 2008: 165). Bu durumdan hareketle gelişmiş ülkelerin kendi ürünlerini tercih etme sebebinin ülke ekonomisine zarar vermeme veya yerli işgücüne yardım etme amaçlı olmadığ 1 tamamen kendi ürünlerini daha kaliteli ve mükemmel olduğuna inandıkları için tercih etme eğilimde bulundukları belirtilebilir.

\subsubsection{Politik Faktörler}

Politik propaganda, bir ülke ile coğrafi yakınlık ve tarihsel ilişki gibi değişkenler politik faktörler arasında yer almaktadır (Mutlu vd., 2011: 56). Tüketici etnosentrizmin gelişmesinde tarihte yaşanmış ekonomik ve politik olayların bunun yanında savaşların etkisi bulunmaktadır. Ülkeler arasında yaşanan olaylar sonucu hem ülkenin kendisine hem de o ülkenin ürünlerine karşı tutum ve davranışlar değişiklik göstermektedir. Ayrıca ülkede yaşanan olayların neticesinde grevler, iş yerlerinin kapatılması gibi durumlar sonucu iş gücüne zarar verilmiştir. $\mathrm{Bu}$ durum tüketicilerin etnosentrik eğilim seviyelerinin artmasına neden olmaktadır (Herche, 1994: 12). Tarihte yapılan savaşlarda yenik düşen ve zulüm gören ülke tüketicilerinin vatansever duygularında artış yaşandığı için buna bağlı olarak etnosentrik eğilimlerinin daha yüksek olduğu belirtilmektedir (Good ve Huddleston, 1995: 36).

11 Eylül 2001'de Amerika Birleşik Devletleri topraklarında gerçekleştirilen terörist saldırı, Amerika Birleşik Devletleri’ni ve halkını önemli ölçüde etkilemiş, ülkeye korumacılık bilinci getirmiştir. Saldırıdan sonra tüketicilerin farklı kültürlere karşı tutum ve davranışlarında değişiklikler meydana gelmiştir. Bu durumun Amerika halkının tüketim alışkanlıklarına da yansıdığı belirtiltmektedir (Arı, 2007: 25). Dolayısıyla Amerika halkının diğer kültür veya ülkelere karşı kendi toplumunu koruma bilincinin oluşması, etnosentrik eğilimlerine de yansımıştır şeklinde ifade edilebilir.

Tüketicilerin dünyayı anlamlandırmalarında ve tüketim tercihlerinde etkili olan ideolojiler, toplumda belli bir düzeni sağlayan inanç ve değerleri kapsamaktadır. Politik nedenler ile bir markayı reddetme davranışının politik yönünü inceleyen 
çalışmada tüketicilerin politik bir ideoloji ile alakalı bir markayı tercih etmeme eğilimi gösterdikleri sonucuna varılmıştır (Sandıkçı ve Ekici, 2009).

Yapılan araştırmalardan hareketle tüketicilerin bir ülkede yaşanan ekonomik, politik ve tarihi olaylardan etkilenmekte; bu durumu tutum ve davranışına yansıtmakta olduğu söylenebilir. Etnosentrik eğilime sahip tüketiciler mensup olduğu ülkeyi koruma amacı ile politik, ekonomik veya tarihi olaylar yaşadığı ülkenin ürünlerini kullanmak istemeyebilirler.

\section{TÜKETİCI ETNOSENTRİZMIIN ÜLKE MENŞE İLE İLİŞKİSi}

Küreselleşme ve teknolojinin etkisiyle firmalar ürünlerini tüm dünyada dağıtma şansı elde ederken aynı zamanda rekabetin arttığı son zamanlarda pazardaki paylarını korumak ve artırmak için de çeşitli stratejiler geliştirmeleri gerekmektedir. $\mathrm{Bu}$ durum kişilere ise kendilerine maksimum fayda sağlayabilecek çeşitli ürün türleri arasında seçim yapma olanağı tanımaktadır. Dolayısıyla tüketici, ürün değerlendirirken pek çok faktörü göz önünde bulundurarak seçim yapmaktadır ve menşe ülke kavramı da önemli bir faktör olarak karşımıza çıkmaktadır.

Tüketiciler satın alma karar sürecinde ürün değerlendirmesi yaparken ürünün markası, fonksiyonu ve niteliği gibi bilgilerin yanında birde ürünlerin "menşe ülke" kavramına dikkat etmektedirler. Menşe ülke, "Bir işletmenin, ürün ya da hizmetin, anavatanı ya da tüketicilerin markayı pazarlayan şirketi kendi zihinlerinde eşleştirdikleri ülkedir.” (Armağan ve Gürsoy, 2011: 69). Köken ülke faktörü olarak da ifade edilen bu kavram, bazı zamanlarda objektif bazı zamanlarda ise psikolojik faktörlerin etkisiyle sübjektif olan bu süreç uluslararası pazarlama literatüründe "menşe ülke etkisi” (Country of Origin) şeklinde de ifade edilmektedir. Bazı ürünlerin ait olduğu ülke açıkça belli olmayabilir. Bu durumda ürünün işlem gördüğü ülke o ürünün menşe ülkesi olarak kabul edilmektedir (Nart, 2008: 156). Bir başka tanıma göre menşe ülke faktörü, tüketicilerin ürünü değerlendirmesine fayda sağlayan öncül bilgi ve etnosentrik olan/olmayan inançları harekete geçiren ipucu şeklinde ifade edilmektedir ( Chryssochoidis vd., 2007: 1521). 
Menşe ülke bilgisinin dört ana nedeni bulunmaktadır (Dosen vd.,2007: 130):

- $\quad$ Giderek büyüyen küreselleşme sebebiyle tüketiciler bir ürünü değerlendirirken ayırt edici faktör olarak o ürünün ülke menşe ve ürün ismini kabul edilebilirlik ve kalite göstergesi olarak algılamaktadır.

- Ürün karmaşasının artması, pazarda birçok üreticinin bulunması gibi nedenler firmaları ürün ve satış yönteminde standartlaşmaya zorlamaktadır. Bu durumda da ayırt edici bir etken olan menşe ülke bilgisinin önemi artmaktadır.

- Çok uluslu işletmeler genellikle gelişmiş ülke menşeilidir. Bu durum çok uluslu işletmelerin gelişmekte olan ülke pazarına girerken "gelişmiş ülke imajı” ile pazara girmesi işletmeye önemli rekabet avantajı sağlamaktadır.

- $\quad$ Tüketiciler küresel iletişim araçları sayesinde ithal ürünlere yönelik pozitif duygular beslemektedirler.

Etnosentrik eğilim göstermeyen tüketiciler yabancı ürün satın alırken nerede üretildiğine önem vermemekle birlikte bu ürünleri sadece yarar sağlayan bir obje şeklinde değerlendirerek tüketici etnosentrizmi ile menşe ülke etkisi arasındaki ilişkiye zemin oluşturmaktadır. Tüketici etnosentrizmi, kişiye kendi ülkesinde üretilen ürünleri tercih etme içgüdüsü ve peşin hüküm veren bir yargıdır. Kişilerin bir ürün ile ilgili izlenimlerinde ön yargı oluşturarak peşin hüküm vermelerine sebep olabilecek faktör ise menşe ülke etkisidir. Bu yüzden satın alınan ürünler için menşe ülke faktöründe hassas olan ve özen gösteren tüketiciler etnosentrik eğilime sahip olma durumunda değildir. Buna karşın etnosentrik eğilime sahip tüketiciler satın aldıkları ürünler için menşe ülke faktöründe son derece duyarlı olmak zorundadır (Ha, 1998: 22). Aynı zamanda düşük etnosentrizme sahip tüketicilerin hassas davrandığı nokta fiyat faktörü iken yüksek etnosentrizme sahip tüketicilerin hassas davranıp önem verdiği faktör menşe ülke kavramıdır (Thelen, 2002: 68).

Ülke menşe kavramı, tüketiciye hem ürünün yerli veya yabancı olduğu hakkında ön bilgi oluşturmaktadır hem de ürünün özellikle hangi ülkeye ait olduğu öğrenilmesinde fayda sağlamaktadır. Çünkü özellikle bazı ülkeler bazı ürünlerde ün yapıp uzmanlaşmaktadır. Bu duruma örnek olarak, Fransa için parfüm, Almanya için otomobil, İsveç için saat, Türkiye için lokum vb. verilebilir. 


\subsection{TÜKETİCILERİN YERLİ VE YABANCI ÜRÜNLERE YÖNELIKK TUTUM VE DAVRANIŞLARI}

Tüketicilerin algılamalarını ve satın alma davranışlarını direkt etkileyen psikolojik etkenlerden biri olarak tutum, "Kişinin bir fikre, bir nesneye veya bir sembole ilişkin olumlu veya olumsuz duygularını veya eğilimlerini ifade etmektedir." (Mucuk, 2017:80). Başka bir tanımda ise tutum; edinilen deneyim ve yaşantı sonucu meydana gelen, alakalı olduğu tüm durum ve objelere karşı dinamik ya da yönlendirici bir şekilde kişinin davranışlarına etki etme durumuna sahip zihinsel ve duygusal hazırlık durumu şeklinde ifade edilmektedir (Allport, 1967, akt, Tavşanc1l, 2006:65). Tutumlar; tecrübe, taklit, pekiştirme ve sosyal öğrenme gibi faktörler ile edinilmekte ve değişime direnç göstermekle birlikte değişebilmektedir. Dolayısıyla doğuştan gelmemekte veya kökeni çocukluğa dayanmamaktadır (Tavşancıl: 2006: 81-82). Davranışlar ise bir taraftan tüketicinin bireysel ihtiyaç ve güdülerinin, algılamalarının, öğrenme sürecinin, tutum ve inançlarının etkisiyle; diğer taraftan kişinin üyesi olduğu toplumda, aile, sosyal sınıf, kültür ve referans grubu gibi sosyo - kültürel faktörlerin etkisi ile çıkmaktadır (Mucuk, 2017: 75).

Davranış - tutum ilişkisi ise Fishbein ve Ajzen tarafından modellenmiş olup şekil 1'de gösterilmiştir. Fishbein ve Ajzen'ın tutumları davranışların muhtemel sonuçlarına yönelik “etkili değerlendirmeler” şeklinde ifade etmektedir. Öznel normlar ise bireye yönelik davranışsal beklentileridir. Bu modele göre davranış, davranışsal isteklerin; davranışsal istekler ise bireyin tutumu ve öznel normlarının bir sonucu olarak meydana gelmektedir. Davranışsal istekler, tutum ile davranışlar arasında köprü görevi üstlenmektedir (Ajzen ve Fisbein, 1975 akt, Kavak ve Gümüşoğlu, 2006: 73)

Şekil 1: Fishbein/Ajzen Model

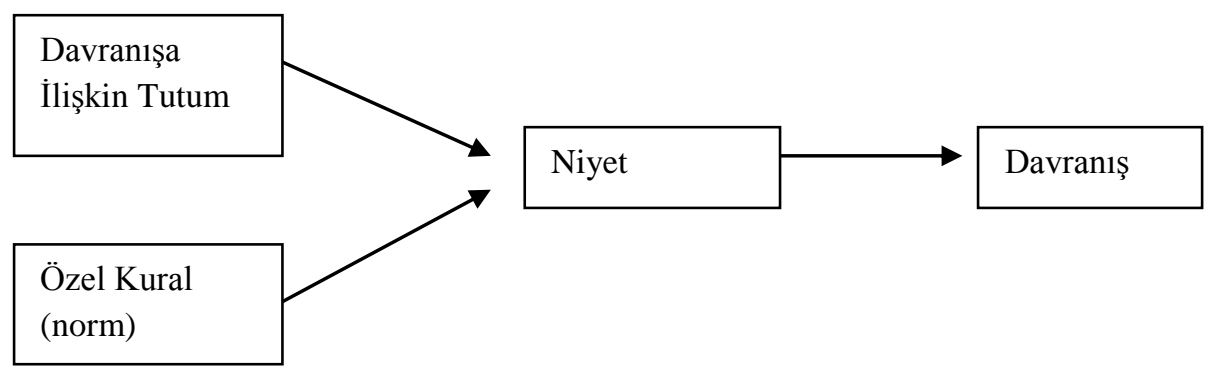


Pazarlama açısından eğilimlerin, tutumların ve davranışların ortaya konulması ve anlaşılması önem arz etmektedir. Pazarlama stratejileri eğilimlere etkide bulunarak arzu edilen; ürün, marka, insan, yer ve duyumlara yönelik olumlu tutumların geliştirilmesini ve istenen davranışın sergilenmesini, bunun sonucunda ise tüketicinin tatmin olmasını amaçlamaktadır (Odabaşı ve Barış, 2017: 179). Küreselleşmenin ve teknolojik gelişmelerin etkisiyle firmalar, ürünlerini dış pazara sunma olanağına sahiptir. Tüketiciler ise hem yerli hem yabancı çok sayıda ve çeşitte istedikleri ürüne daha kolay ve hızlı erişebilme imkânına sahiptir. Bunun sonucu olarak tüketiciler bir ürünün hangi ülkeye ait olduğuna dikkat edebilmekte ve bu durum tercihlerini etkileyebilmektedir.

Bir ürünün marka olarak yerli veya yabancı olup olmaması; iç veya diş pazarda üretilip üretilmemesi tüketici davranışlarına etki eden tutum, algılama ve kişilik faktörlerinde değişik düzeylerde etkisini gösterebilmektedir. Bunlar: (Akın vd, 2009: 490-491)

- $\quad$ Tüketiciler ürünleri nitelikleri açısından değerlendiremedikleri zamanlarda ürünün küresel bir marka olup olmaması veya üretildiği ülke dış bir nitelik olarak onlara ipucu sağlayabilmektedir.

- Satın alma davranışları, ürünün üretildiği ülke ve markası değerlendirilerek gerçekleştirildiği için sembolik fayda sağlamakta ayrıca vatanseverlik, ulusalcılık, milliyetçilik gibi milli duyguların yoğunlaşmasına neden olabilmektedir.

Bir eğilim olan etnosentirizm, tüketicilerin yerli ve yabancı ürünlere yönelik tutum ve davranışlarına etki etmektedir. Ürünlerin fiyatı, kalitesi ve özellikleri; ülkelerin gelişmişlik düzeyi, imajı ve özellikle bir ürünle özdeşleşmiş olup o ürün ile ün yapması; tüketicilerin milliyetçi duygu seviyeleri ve yerli ekonomiyi korumak istemeleri gibi değişkenler yerli veya yabancı ürün tercihlerini etkileyebilmektedir.

Yerli ürünlere kıyasla yabancı ürünlerin tercih edildiği durumlar genellikle şu şekildedir: Tüketicilerin daha kaliteli yabancı ürünlere ulaşma imkânı mümkünken daha düşük kalitedeki yerli ürünleri tercih etmemekte aynı zamanda tüketicilerin yabancı ürünlere yönelik tutumları ürün gruplarına göre değişiklik göstermektedir (Knigt, 1999: 152). Tüketiciler yabancı ürünlere sahip olduklarında yabancı ürünlerin kendilerine prestij kazandırdığını düşünmektelerdir (Ettenson,1991: 15). Suriye ve 
Türkiye gibi iki komşu ülkelerin karşılaştırıldığı ürün satın alma niyeti ve ülkelerin birbirine olan tutumlarının incelendiği araştırmada her iki ülke tüketicilerinin etnosentirk eğilimleri arasında anlamlı bir farklılık olmadığı, iki ülke tüketicilerinin de benzer etnosentrik eğilime sahip olduğu sonucuna ulaşılmıştır (Mutlu vd., 2018: 68). İki ülkenin satın alma niyetine bakıldığında Suriyeli tüketicilerin Türk mallarına daha 1lımlı bakmakta olduğu belirtilmektedir. Malezya'daki üniversite öğrencilerinin telefon kullanımında algılanan kalite, ülke kökeni ve etnosentrizm seviyelerinin incelendiği çalışmada gelişmiş ülke ürünlerinin daha kaliteli algılandığ konulmaktadır (Lee, 2011: 28).

Yabancı ürünlere kıyasla yerli ürünlerin tercih edildiği durumlara örnek verildiğinde, Çukurova Üniversitesinde satın alma kararlarında etnosentrizmin etkisinin incelendiği çalışmada, kategorilere ayrılmış ürünler arasında en çok gıda üzerinde en az ev aletlerinde yerli ürün tüketme eğilimi gösterildiği ortaya konulmuştur. Bu durumun sebebinde ise Türkiye'de özellikle gençlerin çok olduğu örneklemde, yerli ürünlerin yabancı ürünlere tercih edilmesi durumun da işsizliğe neden olabileceği, ülke ekonomisine zarar verebileceği düşüncesi yer almaktadır. Ev aletleri kısmında ise katılımcılar yerli ürünlere güvenmemektedir. Çünkü bu kategoride ithal ürün satın almanın ekonomik açıdan ülkeye zarar vereceği düşüncesinde olmadıkları sonucuna ulaşılmıştır (Arı, 2007: 77-78). ABD ve Kanada tüketicileri üzerine etnosentrik eğilimleri ile ulusal kimlik kavramını kanıtlamak amacıyla yapılan bir diğer çalışmada, yüksek etnosentrik eğilime sahip tüketicilerin yerli ürün satın almak için daha yüksek fiyat ödeyebileceği; düşük etnosentrik eğilime sahip tüketicilerin ise yabancı ürün satın alma eğiliminde istekli olduğu sonucuna ulaşılmıştır (Lantz ve Loeb, 1996: 9).

Genel olarak incelendiğinde yerli ürün tercih eden tüketicilerin etnosentrik eğilimleri yüksek olduğu ve kendi ülkelerinin ürünlerinin mükemmelliğine inandıkları, yabancı ürünleri tercih eden tüketicilerin ise ithal ürünleri daha kaliteli algılaması ve kendilerine prestij kazandırdığı inancı yer aldığı söylenebilir.

Yerli ve yabanc1 ürünlerin tercih edilme nedenleri ile bu ürünleri değerlendirirken tüketicilerin sahip oldukları değerlendirme kriterleri hakkında yapılan araştırmalar değişik sonuçlar içermektedir. Bu farklılığın basit bir ifadeyle 
nedeni her bireyin farklı satın alma davranışı sergilemesi ve değerlendirme kriterinin birbirinden farklı olmasıdır. Farklılığın diğer önemli sebebi ise farklı ülke vatandaşlarının sahip oldukları gelenek görenekler ve kültürel farklılıklardan doğan etkenlerdir. Bunun yanında tüketiciler bazı ürün grupları için yerli ürün satın almayı tercih ederken bazı ürün grupları için yabancı menşeli ürün satın almayı tercih ettikleri belirtilmektedir (Özçelik ve Torlak, 2011: 365).

\section{TÜKETICI ETNOSENTRIZM GELIŞTIRILLMESİ VE CETSCALE ÖLÇEĞİ}

Etnosentrizmin tüketici davranışı ile ilişsilendirilmesi sonucu oluşan tüketici etnosentrizm kavramı pazarlama literatürüne kazandırılması ile birlikte bu kavramın ölçülmesi gerektiği ön görülmüştür. Bu doğrultuda ilk olarak 1984 yılında açık uçlu sorulara verilen cevaplar ile Shimp tarafından oluşturulan bir çalışmada, yüksek ve düşük etnosentrizm derecelerine sahip tüketicilerin gruplandırılması ve bu gruplar arasındaki farklı yönlerin ortaya konulması amaçlanmıştır (Shimp, 1984:286). Bu çalışma bağlamında 1987 yılında Shimp ve Sharma tarafından Amerikalı tüketicilerin yabanc1 ürünlere karşı yerli ürün tercihlerindeki etnosentrik eğilim düzeylerinin belirlenmesi amacı ile Tüketici Etnosentrik Eğilim Ölçeği “CETSCALE (Consumer Ethnocentric Tendency Scale)" isimli yeni bir ölçek oluşturulmuştur. CETSCALE ölçeğinde tutumlardan çok eğilimlerin ölçülmesi esas alınmaktadır. Çünkü tüketicinin herhangi bir araba modeli gibi belli bir nesneye karşı hislerini göstermek için tutum kavramı kullanılmaktadır. Buna karşın eğilim kavramı ise tüm yabancı ürünlere karşı davranışları etkileyecek hisler toplamı olarak ifade edilmektedir (Shimp ve Sharma, 1987: 281).

Katılımcıların ahlaki açıdan vatanseverlik duygularına aykırı olması aynı zamanda ülke ekonomisine ve işgücüne zarar vermesi nedenleriyle ithal ürünleri satın almanın etik olmadığı güdüsünü veren ölçek, katılımcılardan bu görüşe ne denli katıldıklarını ifade etmek istemektedir (Ueltschy, 1998:16).

CETSCALE ölçeğinin geliştirilmesi aşamasında, T. A. Shimp ve S. Sharma tarafından 800'den fazla Amerikalı tüketicilere üretimi yabancı ülkelerde yapılan ürünleri satın almalarının ne derece doğru olduğu hakkındaki görüşleri sorulmuştur. 
Verilen cevapların içerik analizi, araştırmacının literatür incelemesi ile tüketicilerin yabancı ürünlere eğilimlerinin yedi farklı boyuttan etkilendiği sonucuna ulaşılmıştır. Bunlar; tüketicilerin fiyat - değer algıları, etnosentrik eğilimleri, seçimin rasyonelliği, kişisel ilgi alanları, karşılıklılık kuralı, seçimin özgürlüğü ve kısıtlar - mantalite şeklindedir. Bu yedi boyutu ölçmek için 225 tane likert maddesi oluşturulmuş ancak gereksiz maddelerin çıkarılmasıyla madde sayısı 180 'e indirgenmiştir. Daha sonra takip eden sadeleştirmeler sonucu ifadelerin düzenlenmesi ile tek bir boyuta düşürülmüştür. Bu boyutları ölçümlemek için oluşturulan 25 maddelik önerme sayısı, tekrar doğrulayıcı faktör analizine tabi tutularak 17 maddeye düşürülmüş ve son hale getirilmiştir (Shimp ve Sharma, 1987: 280-282).

Tüketici etnosentrizmini ölçmek için geliştirilen CETSCALE ölçeği 17 maddelik son halini aldıktan sonra güvenilirlik ve geçerliliğinin test edilmesi amacı ile dört faklı bölgeye uygulanmış, genel itibari ile her bölgede güvenilirliği ve geçerliliği faktör yükleme olan 0,5 güvenilik kriterini karşılayarak ispat edilmiştir (Martinez vd., 2000:1357). CETSCALE ölçeği, ilk kez geliştirildiği 1987 yılından bu yana uluslararası birçok araştırmada test edilip çeşitli ölçütlerle güvenilirliği ve geçerliliği ölçülmekle birlikte bugüne kadar yapılan birçok çalışmada da bu durum kanıtlanmıştır (Arı, 2007: 29). 


\section{İKINCİ BÖLÜM}

\section{KUŞAKLAR ve Y KUŞAĞININ ÖZELLIKLERİ}

\section{KUŞAK KAVRAMI}

Kuşaklar kavramı ilk kez 1928 yılında Alman bir sosyolog olan Karl Mannheim tarafından yazılan kitapta ileri sürülmüştür. Fakat şuanki kuşakları kapsayan sinıflandirmalar ilk olarak Inglehart tarafindan ilerleyen zamanlarda da Strauss ve Howe tarafından 1991 yılında yazılan kitap ile hızını artırmaya başlamış ve bazı araştırmacılar bu kuramı "Strauss-Howe Kuşak Kuramı" şeklinde isimlendirmiştir. Kurama göre toplumlarda yaşanan savaş, ekonomik buhran gibi birçok önemli tarihsel olay ve sosyal değişimlerin aynı toplumda yer alan bireylerin tutum, davranış, inanç ve eğilimlerini etkileyebileceği düşünülmektedir. Kişilerin davranışları yaşadığı dönemin özelliklerine göre şekillenmesi nedeniyle belli dönem aralıklarında doğup büyüyen aynı yaş grubu kişilerin birbirleri ile benzer davranış özellikleri sergilediği ve bu benzer davranış özelliklerinin devam edebileceği düşünülmektedir (Arslan ve Staub, 2015: 5).

Yıllar boyunca yayınlanan birçok bilimsel çalışmada "Kuşak" kelimesi çeşitli şekillerde tanımlanmaktadır. Türk Dil Kurumu "Kuşak" kelimesini; yaklaşık olarak aynı yıllarda doğup aynı dönemin şartlarını yaşamış dolayısıyla birbirlerine benzer sıkıntı ve kaderi paylaşmış, benzer ödevler ile yükümlü olmuş kişilerin topluluğu olarak tanımlamaktadır (tdk.gov.tr). Bir başka tanıma göre yıllar süresince aynı zaman dilimi içerisinde ortak sosyal ve tarihsel olaylar ile karşı karşıya kalıp benzer deneyim ve görüşleri paylaşan kişilerin oluşturduğu gruplardır (Mannheim 1952, akt, M.Crumpacker ve J.M. Crumpacker 2007:351). Bir toplumda aşağı yukarı aynı tarihlerde doğan kişilerden meydana gelen yaş gruplarına hitap eden kuşak kavramı; bir nesil ile diğer bir nesil arasında geçen dönemi kapsamaktadır (Marshall, 1999: 439). Kuşaklar bir diğer anlamıyla nesiller, ebeveynlerin çocukları ile arasındaki kültür ve yaş farkını da belirtmekte olup bu süreç 25 ile 30 yılları arasını kapsamaktadır. Kuşakların her biri farklı özellik ve değer yargılarına sahip olmaları nedeniyle kişiler ait olduğu kuşak grubunun davranışlarına benzer özellik gösterirken 
diğer kuşak grubunun davranışlarından farklı özellikler sergilemektedir (Chen, 2010: 132).

Her kuşak kendine özgü karakteristik özelliklere, temel yargı ve tutumlara, güçlü ve zayıf yönlere sahiptir (Lower, 2008: 80). Tüm bu tanımlardan hareketle kuşak kavramı; doğum yılları birbirine yakın, beraber aynı zaman ve deneyimleri paylaşan, siyasi, sosyal ve ekonomik olaylar gibi çeşitli olaylardan etkilenerek hemen hemen aynı tepkileri veren insan topluluğu şeklinde tanımlanabilir. Bir başka ifadeyle; insan hayatında sosyal rollerin kazanıldığı çocukluk, yetişkinlik ve yaşlılık gibi farklı evrelerde birlikte yaşamış insan topluluğu şeklinde ifade edilebilir.

\subsection{KUŞAKLARIN SINIFLANDIRILMASI}

İnsanlar çeşitli istek ve arzuları, alışkanlık ve deneyimleri neticesinde farklı satın alma davranışları göstermektedir. Bu nedenle pazarlamacılar hitap edeceği müşteri kitlesini belirlemek ve onlara daha kolay ulaşabilmek amaciyla büyük olan pazarı daha küçük birimlere bölme yoluna gitmektedir. Bu birimlerden bir tanesi de insanları doğum yıllarına göre kuşaklara ayırma yöntemidir (Yaşa ve Bozyiğit, 2012: 33). Doğum oranı ile aynı dönemde gerçekleşen olaylar kuşak sınıflandırmasının ana faktörlerini oluşturmaktadır. Kuşağın başlangıcı, doğum oranının artıp aynı yoğunlukta devam etmesi ya da aynı seviyede kalması iken kuşağın son bulması doğum oranının azalması sonucu meydana gelmektedir (M.Crumpacker ve J.M. Crumpacker 2007:352)

Kuşakların sınıflandırılması; toplumun yaşadığı önemli tarihsel olaylara, ekonomik krizlere, teknolojik gelişmelere bağlı olarak belirlenmektedir. Bir kuşağın ne zaman başlayıp ne zaman sona erdiğine dair yapılan araştırmalarda kesin bir ifade bulunmamakla birlikte çeşitli yazarlara göre farklı tanımlar yapılmaktadır (Reeves ve Oh, 2008: 296). Tablo1'de kuşakların sınıflandırmaları farklı yazarlar tarafından tarih aralıkları ile birlikte yer almaktadır. 
Tablo 1 Kuşak Sınıflandırması ve Tarih Aralıkları

\begin{tabular}{|c|c|c|c|c|c|}
\hline Kaynak & Sinıflandırm & & & & \\
\hline $\begin{array}{l}\text { Howe and } \\
\text { Strauss } \\
(2000)\end{array}$ & $\begin{array}{l}\text { Sessiz } \\
\text { Kuşak } \\
\text { 1925-1943 }\end{array}$ & $\begin{array}{l}\text { Patlama } \\
\text { Kuşağ1 } \\
\text { 1943-1960 }\end{array}$ & $\begin{array}{l}13 \text { Kuşak } \\
1961-1981\end{array}$ & $\begin{array}{l}\text { Milenyum } \\
\text { Kuşağ1 } \\
\text { 1982-2000 }\end{array}$ & - \\
\hline $\begin{array}{l}\text { Lancester } \\
\text { Stillman } \\
(2002)\end{array}$ & $\begin{array}{l}\text { Gelenekçiler } \\
1900-1945\end{array}$ & $\begin{array}{l}\text { Bebek } \\
\text { Patlamas1 } \\
1946-1964\end{array}$ & $\begin{array}{l}\text { X Kuşağ1 } \\
1965-1980\end{array}$ & $\begin{array}{l}\text { Milenyum, } \\
\text { Y Kuşağı, } \\
\text { Gelecek } \\
\text { Kuşak, } \\
\text { Patlama } \\
\text { Kopyası } \\
\text { 1981-1999 }\end{array}$ & - \\
\hline $\begin{array}{l}\text { Martin and } \\
\text { Tulgan } \\
(2002)\end{array}$ & $\begin{array}{l}\text { Sessiz } \\
\text { Kuşak } \\
\text { 1925-1942 }\end{array}$ & $\begin{array}{l}\text { Bebek } \\
\text { Patlamas1 } \\
1946-1960\end{array}$ & $\begin{array}{l}\text { X Kuşağ1 } \\
1965-1977\end{array}$ & $\begin{array}{l}\text { Milenyumlar } \\
1978-2000\end{array}$ & - \\
\hline $\begin{array}{l}\text { Oblinger } \\
\text { and } \\
\text { Oblinger } \\
(2005)\end{array}$ & $\begin{array}{l}\text { Yetişkinler } \\
1946\end{array}$ & $\begin{array}{l}\text { Bebek } \\
\text { Patlaması } \\
1947-1964\end{array}$ & $\begin{array}{l}\text { X Kuşağ } 1 \\
1965-1980\end{array}$ & $\begin{array}{l}\text { Y Kuşağı, Net } \\
\text { Kuşağ1, } \\
\text { Milenyumlar } \\
\text { 1981-1995 }\end{array}$ & $\begin{array}{l}\text { Milenyum } \\
\text { Sonras1 } \\
\text { 1995- } \\
\text { sonras1 }\end{array}$ \\
\hline $\begin{array}{l}\text { Tabscott } \\
(1998)\end{array}$ & - & $\begin{array}{l}\text { Bebek } \\
\text { Patlamas1 } \\
1946-1964\end{array}$ & $\begin{array}{l}\text { X Kuşağı } \\
1965-1975\end{array}$ & $\begin{array}{l}\text { Dijital Kuşak } \\
\text { 1976-2000 }\end{array}$ & - \\
\hline $\begin{array}{l}\text { Zemke vd. } \\
(2000)\end{array}$ & $\begin{array}{l}\text { Eski } \\
\text { Askerler } \\
\text { 1922-1943 }\end{array}$ & $\begin{array}{l}\text { Bebek } \\
\text { Patlamas1 } \\
1943-1960\end{array}$ & $\begin{array}{l}\text { X Kuşağı } \\
1960-1980\end{array}$ & $\begin{array}{l}\text { Gelecektekiler } \\
1980-1999\end{array}$ & - \\
\hline
\end{tabular}

Kaynak: Reeves \& Oh, 2008: 296-297

Kuşaklar genel olarak beş farklı tarih aralıklarında sınıflandırılmaktadır Bunlar; Savaş ve Geleneksel kuşak olarak da bilinen Sessiz kuşak (1925-1945 tarihleri arasında doğanlar), Babby Boomers olarak da bilinen Bebek patlaması (1946-1964 tarihleri arasında doğanlar), Gen X olarak da bilinen X kuşağı (1965- 
1980 tarihleri arasında doğanlar), Gen Y, Milenyum, Gen Me, olarak da bilinen Y kuşağı (1980-1999 tarihleri arasında doğanlar), Z kuşağı (2000 ve sonrası doğanlar) (Akdemir vd., 2013:14).

Tablo 2 Kuşakların Kişisel Özellikleri

\begin{tabular}{|c|c|c|c|c|}
\hline & Sessiz Kuşak & $\begin{array}{l}\text { Patlama } \\
\text { Kuşağı }\end{array}$ & X Kuşağı & Y Kuşağ \\
\hline Öz Değerler & $\begin{array}{l}\text { Otoriteye } \\
\text { saygil1, } \\
\text { İtaatkâr, } \\
\text { disiplinli }\end{array}$ & $\begin{array}{l}\text { İyimser, bağlı } \\
\text { (ilgili) }\end{array}$ & $\begin{array}{l}\text { Şüpheci, } \\
\text { eğlence } \\
\text { düşkünü, } \\
\text { formaliteye } \\
\text { uymayan }\end{array}$ & $\begin{array}{l}\text { Gerçekçi, kendine } \\
\text { güvenen, aşı1 } \\
\text { eğlence düşkünü, } \\
\text { sosyal }\end{array}$ \\
\hline Aile & $\begin{array}{l}\text { Geleneksel, } \\
\text { çekirdek }\end{array}$ & Parçalanmış & $\begin{array}{l}\text { Çalışan } \\
\text { ebeveynlerden } \\
\text { oluşan }\end{array}$ & $\begin{array}{l}\text { Farklı etnik } \\
\text { yap1 ve kültürlerin } \\
\text { evliliklerinden } \\
\text { oluşan }\end{array}$ \\
\hline Eğitim & Bir hayal & Yaşam hakk1 & $\begin{array}{l}\text { Hedefe } \\
\text { ulaşmak için } \\
\text { bir yol }\end{array}$ & $\begin{array}{l}\text { İnanılmaz } \\
\text { gider }\end{array}$ \\
\hline İletişim & $\begin{array}{l}\text { Kurmalı } \\
\text { telefonlar, } \\
\text { yüzyüze, k1sa } \\
\text { notlar }\end{array}$ & $\begin{array}{l}\text { Tuşlu } \\
\text { telefonlar, her } \\
\text { zaman ara }\end{array}$ & $\begin{array}{l}\text { Cep } \\
\text { telefonları } \\
\text { sadece } \\
\text { işteyken ara }\end{array}$ & $\begin{array}{l}\text { Görüntülü } \\
\text { telefonlar, internet, } \\
\text { e-posta }\end{array}$ \\
\hline Para İle İlişki & $\begin{array}{l}\text { Biriktirir, } \\
\text { peşin öder }\end{array}$ & $\begin{array}{l}\text { Şimdi alır } \\
\text { sonra öder }\end{array}$ & $\begin{array}{l}\text { Tedbirli, } \\
\text { ölçülü, sakla }\end{array}$ & $\begin{array}{l}\text { Harcamak için } \\
\text { kazanır }\end{array}$ \\
\hline
\end{tabular}

Kaynak: Kuyucu, 2017:850

\subsubsection{Sessiz Kuşak}

"Gelenekselciler" veya "Savaş Kuşağı" şeklinde de adlandırılan Sessiz Kuşak, 1925-1945 tarihleri arasında doğan kişilerin oluşturduğu bir kuşaktır. Bu dönemin kişileri İkinci Dünya Savaşı gibi dünya çapındaki en önemli olaylardan birine ve ekonomik buhrana tanık olmuş kişilerdir. Bu dönem Türkiye'de ise Cumhuriyet Dönemi'nin tek partili olduğu yıllara tekabül etmektedir (Demirkaya vd., 2015: 188). Türkiye Cumhuriyeti'nin ilk yıllarında ortaya çıkan bu kuşak, dünya 
savaşları görmüş, yokluklar yaşamış aynı zamanda Büyük Buhran'ın ve İkinci Dünya Savaşı'nın ülkede oluşturduğu yıkıcı atmosferde her şeyden önce hayatta kalmanın ehemmiyetini öğrenerek büyümüşlerdir (Acılığlu, 2015: 24).

Sessiz kuşağı oluşturan kişiler II. Dünya Savaşı çıktığı dönemde yaş olarak savaşa katılamayacak kadar küçük olmakla birlikte savaşın etkisini en çok yaşayan kişilerdir. Yerel sosyal gruplar, geniş aileler ve yoğun komşuluk ilişkileri bu kuşağın kültürel unsurlarını oluşturmaktadır. Bu kuşağın esas değerleri otoriteye karşı saygı, sadakat, toplumsal değerlere kendini adama ve çok çalışma şeklindedir. Yaşama dair hayat felsefeleri ise yaşamak için çalışmanın gerekli olduğu öngörüsüdür (Akdemir vd., 2013: 14).

Sessiz kuşağın genel özellikleri ise kendilerini yaptıkları işe adama, çok çalışma ve fedakârlık gösterme bunun yanında gelenek ve kurallara uygun davranışlar sergileme, otoriteye karşı saygılı ve sabırlı olma şeklinde sıralanmaktadır (Ayhün, 2013: 103). Savaş ve ekonomik buhrana şahit olduklarından dolayı yaşamanın değerini bilen, hayatlarını devam ettirebilmeleri için çalışmanın ne kadar önemli olduğunu anlayan sessiz kuşak üyeleri, otorite kurallarına uygun davranışlar sergilemekle birlikte sabır eşiği yüksek kişilerden oluşmaktadır. Günümüzde de bu kuşak genellikle alışverişlerde nakit para ödeyen, tasarruflu, birikim yapan, kıtlık ne demek onu çok iyi bilen ve ona göre yaşayan kişilerdir.

\subsubsection{Babby Boomers (Patlama Kuşağı)}

İkinci Dünya Savaşı'ndan sonraki yıllarda 1 milyar bebeğin doğmasından dolayı "Babby Boomer" yani "Patlama Kuşağı” olarak adlandırılan 1946 - 1964 tarihleri arasında doğan bu nesil; büyüme, refah, mal ve hizmete özlemin ağır bastığı bir dönemde yetişmişlerdir. Bu tarihlerde doğan kişilere "Soğuk Savaş” dönemi çocukları da denilmekle birlikte doğu - batı ikili dünya içerisinde 68'lileri yaratmış bir kuşak olarak öne çıkmaktadır (Senbir, 2004: 24). Tüm kuşaklar içinde Babby Boomers'ları farklı bir boyuta taşıyan en önemli nitelikleri, efsaneleştirilen 68 kuşağının yapıcısı olmalarıdır. 68'liler televizyonun etkin bir iletişim aracı olduğunu fark eden ilk kuşak olup televizyon ile yetişmişlerdir. Ayrıca bu özellikleri, onların yerel olarak başlayan hareketi, televizyon vasıtasıyla dünya çapına taşımalarını 
kolaylaştırmıştır. Bir taraftan kendi özgürlüklerine düşkün, bireyci, dünyayı keşfedip sonuna kadar yaşama odaklı; diğer taraftan olumlu yaklaşımlı, yeniliklere açık, hedef odaklı aynı zamanda kadın erkek ilişkilerinde ise muhafazakar kişilik özellikleri gösteren bir kuşaktır. Genel olarak bu kuşak çalışmayı seven, çok çalışan ve toplumsal sorumluluk bilinci gelişmiş kişiler olarak değerlendirilmektedir (Altuntuğ, 2012: 205).

Hayatta kalma mücadelesine sebebiyet veren kıtlık döneminin geride kaldığg, nispeten varlığa kavuşulduğu bu dönemde savaş yıllarının bıraktığı izler devam etmektedir. Kuşak temsilcileri "çalışmak için yaşamak" düşüncesini benimseyerek sessiz kuşak gibi fedakâr ve itaatkarlardır. İyi bir hayat sürdürmek için çok çalışmak gerektiğini düşünen bu kuşak temsilcileri, "Şimdi çok çalış ileride karşılığını alırsın." düşüncesine sahiplerdir. Patlama kuşağı aynı beklentiyi kendinden genç kuşaklardan da bekleyerek kendilerinin daha engin bir bilgiye sahip olduğu düşüncesindelerdir. Kendi kararlarının $\mathrm{X}$ ve $\mathrm{Y}$ kuşağı tarafından dinlenmesini ve uygulanmasını beklemektelerdir. Bunun yanında genç kuşaklar tarafından ise uyumsuz, teknolojiden uzak, yeniliklere karşı kapalı olarak vasıflandırılmaktalardır (Acılıoğlu, 2017: 2425).

\subsubsection{Kuşağı}

1965 - 1979'lu yıllar arasında dünyaya gelen kişiler X kuşağı olarak adlandırılmaktadır (Kyles 2005: 54). 70'li yıllarda petrol krizinin sebep olduğu sıkıntılardan dolayı geleceğe dair korku ve kaygı ile büyüdükleri için çok çalışıp para kazanmaya odaklanmışlardır (Altuntuğ, 2012: 205-206). Ara kuşak anlamına gelen X kuşağı, 1965 - 1979'lu yıllarda dünya çapında radikal değişim ve dönüşüm olaylarına tanık olduklarından "geçiş dönemi çocukları" olarak da belirtilmektedir (Senbir, 2004: 24). Soğuk Savaş döneminin bitmesinden evlere renkli televizyonların girmesine, 1980 darbesi ile birçok insanın gözaltına alınması ve sonrasındaki yasaklı yıllardan, kapalı Türkiye ekonomisinin liberalleşerek ithal tüketime açılması gibi bir çok değişim bu kuşağın büyüme evresinde olmuştur (Acılığlu, 2017: 26).

1980 darbesinden sonra gençliğini yaşayan X kuşağı, otorite tarafindan ezilmiş bir toplumda büyüdükleri için otoriteye karşı korku ve saygı duyguları 
beslemekle birlikte otoriteden pek haz etmemektelerdir. Dolayısıyla bu kuşak, sosyal olaylara karşı oldukça duyarlı ama çekingen bir eğilim sergilemektedir (Çatalkaya, 2014: 18-19).

Genel olarak iş motivasyonları yüksek, otoriteye saygılı, aynı işte uzun yıllar çalışmış, kanaat duyguları yüksek ve sadık özelliklere sahip kişilerdir. Teknolojik gelişmelerin ortaya çıktığı bir döneme denk gelmeleri ile zorunlu olarak teknolojiyi kullanmaya başlamışlardır. Kadınların iş hayatına adım atması ve az sayıda çocuk sahibi olması bu dönem içinde sıralanabilir (Keleş, 2011: 131).

\subsubsection{Y Kuşağı}

Y kuşağı kavramı ilk olarak 1993 yılında o dönemdeki gençlerin önceki X kuşağı ile farklılıklarını belirtmek amacıyla kullanılmıştır (Straus ve Howe, 1992: 54). Yapılan birçok araştırmada Y kuşağının kapsadığı tarih aralığı net olarak belli olmamakla birlikte görüş ayrılıkları bulunmaktadır. Bazı araştırmacılar 1980 - 2000 yılları arasında dünyaya gelenleri Y kuşağına dahil etmektedir (Miller ve Washington, 2011:174). Bazı araştırmacılar ise Y kuşağı kapsamına 1977-2000 yılları arasında dünyaya gelenler dahil etmektedir (Kotler ve Armstrong, 2004: 465). $\mathrm{Bu}$ araştırmada 1980 ile 2000 yılları arasında doğanlar Y kuşağı olarak ifade edilmektedir. Y kuşağının farklı araştırmacılar tarafından farklı tarih aralıkları aşağıda gösterilmiştir. 
Tablo 3 Y Kuşağının Atfedilen Yaş Aralıkları

\begin{tabular}{|l|l|}
\hline Araştırmacılar & $\begin{array}{l}\text { Atfedilen Y Kuşağı Yaş } \\
\text { Aralığı }\end{array}$ \\
\hline Arsenault (2004) & 1981 - 2000 \\
\hline Broadbidge, Maxwell ve Ogden (2007) & $1978-2000$ \\
\hline $\begin{array}{l}\text { Ergil (2013); Keleş (2011); Haeberle, Herzberg ve } \\
\text { Kobby(2009); Crumpacker ve Crumpacker (2007); }\end{array}$ & $1980-1999$ \\
\hline $\begin{array}{l}\text { Howe ve Strauss (1997) } \\
\text { Kotler ve Armstrong (2004); Bush, Martin ve Bush } \\
\text { (2004); Hacker (2008) }\end{array}$ & $1977-2000$ \\
\hline Lancaster ve Stillman (2002) & $1982-2004$ \\
\hline Lower (2008) & $1981-1989$ \\
\hline Miller ve Washington (2011); Salahuddin (2010) & $1980-2000$ \\
\hline Pekala (2001) & $1980-2001$ \\
\hline Seçkin, 2005 & $1980-2001$ \\
\hline Tolbize (2008) & $1981-1995$ \\
\hline Washburn (2000) & $1982-2003$ \\
\hline Yelliamsikalan ve Altın (2010) & $1977-1994$ \\
\hline
\end{tabular}

Kaynak: Yüksekbilgili, 2015:260

Y kuşağının kendinden önceki kuşaklardan farkını belirmek amacı ile "EchoBoomers", "İnternet kuşağı", "Millenial" ve "Nexters" gibi farklı isimlerde kullanılmaktadır (Broadbirdge, vd., 2007: 135). Önceki kuşaklar ile kıyaslandığında Y kuşağı; ekonomik koşul olarak daha olumlu, dünya üzerinde büyük savaşların ve 
kıtlığın yaşanmadığı bir ortamda yetişmiştir. İnternet başta olmak üzere küresel iletişime imkan sağlayan cep telefonu ve sosyal medya gibi teknolojilerin büyük bir hızla geliştiği ve kullanıldığı bir dünyanın çocuklarıdır (Acılıoğlu, 2017: 28).

Türkiye'de 1980 yılından sonra ekonomik, siyasi ve kültürel açıdan kayda değer bir değişim yaşanmıştır. Şehirleşme ve teknolojik gelişmeler ile yaşanan değişimler toplumu etkileyerek önceki kuşaklar ile aralarında büyük bir farklılık yaratmıştır. Türkiye'de Y kuşağı kapsamında olan 25 milyon kişi bulunmaktadır yani her üç kişiden bir tanesi Y kuşağı üyesidir (Marketing Türkiye 2016: 84). Yaşam şartlarında oluşan değişimler Y neslinin diğer nesillerden farklı beklenti, ümit ve tercihe sahip olmalarına sebebiyet vermiştir. Çağımızda Y kuşağı genellikle gezip eğlenmeye düşkün, alışverişi seven, yeni şeyler deneme peşinde olan, başarılı, hayallerin peşinden koşan, sorgulayan ve sevdiklerine vakit ayıran niteliklere sahiptir (Tufur, 2011: 36).

2011 yılında Conento tarafında yapılan araştırmada Y kuşağı 4 farklı yaş grubuna ayrılmıştır. Bu gruplar aşağıdaki tabloda gösterilmiştir (Tufur, 2011: 35).

Tablo 4 Y Kuşağının Yaşam Basamakları

\begin{tabular}{|l|l|l|l|}
\hline Yaş Aralı̆̆ı & Dönem & Grup Özellikleri & Yaşam \\
Basamakları
\end{tabular}

Kaynak: Tufur, 2011:35 


\subsubsection{Z Kuşağı}

Y kuşağının ardından gelen ve bambaşka bir kuşak olan Z kuşağı, 2000 yılından sonra dünyaya gelenleri kapsamaktadır. Strauss ve Howe bu kuşağın çok fazla bireyselleşmeye yöneleceğini ve yalnızlık yaşayabileceğini ifade etmektedir. Z kuşağı adlandırılmasında ise "Kuşak I", "Next Generation", “iGen", "Instant Online”, “İnternet Kuşağı, “.com Çocukları” gibi pek çok farklı isimler kullanılmaktadır (Başol ve Çetin Aydın, 2014: 4).

Büyük bir kısmı hala çocukluğunu yaşayan $\mathrm{Z}$ kuşağı üyeleri; sosyal, ekonomik, kültürel ve teknolojik gelişmeler neticesinde, sergiledikleri davranışlar ve aldıkları kararlar üzerinde kendi yaşlarından daha üstün etkileri bulunmaktadır. $\mathrm{Bu}$ durumda Z kuşağının alışılagelmiş pazarlama ve tüketim alışkanlıklarını önemli derecede değiştirecekleri aynı zamanda ilerleyen yılların tüketici profilini şekillendirecekleri düşünülmektedir. Diğer kuşaklardan farklı olarak Z kuşağı, aşırı hızlı ve kırılmaların yaşandığı değişiklere tanık olmuş, en önemlisi doğmadan önce tanımlanabilen ilk kuşak olmuştur. Teknolojinin gelişmesi ile istedikleri anda istedikleri yerde istedikleri kişiler ile rahat bağlantı kurabilen Z kuşağı; internete hakim, birçok işi aynı anda yapabilen, aceleci, alışılmışın dışında davranış sergileyen, yaratıcı, anlık tüketen, otoriteden pek haz almayan, sonuç odaklı düşünen özelliklere sahiptir (Altuntuğ, 2012: 206).

Dünyaya geldikleri ilk andan itibaren teknoloji ile iç içe olan Z kuşağı yaşamlarının her anında teknolojiyi ileri seviyede kullanarak diğer kuşaklar tarafından internet bağımlısı olarak adlandırılabilirler. Bu kuşak genellikle eski kuşaklara göre farklı davranışlar sergileyebilmektedir. Sokakta oynamak yerine cep telefonu, i-Pod, bilgisayar, Playstation ile oynamayı tercih etmekte, arkadaşları ile sosyal medya üzerinden daha fazla iletişim kurmakta, alışverişlerde ise mağazaya gitmek yerine evde internetten online alışverişi tercih etmektedir.

Kuşakların aynı sosyal etkide olmamaları, aynı yararlara sahip olmamaları ve önem verdikleri konuların farklı olması durumu pazarlama, tüketim ve reklam alanlarını da etkilemektedir. Bu yüzden her kuşağın tüketimi ayrı olmakla birlikte her kuşak için uygulanan pazarlama ve reklan stratejilerinin de farklı olması söz konusudur (Bakırtaş, 2016: 27). 


\subsection{TÜKETİİ DAVRANIŞLARINDA VE PAZARLAMANDA KUŞAK KAVRAMININ ÖNEMI}

Teknolojinin gelişmesi ve hızlı bir şekilde yayılması ile her yaş grubuna özel hitap edebilen farklı bir çok ürün ortaya çıkmış ve ürüne kolayca ulaşma imkanı sağlanmıştır. $\mathrm{Bu}$ durum işletmelerin girdiği pazarda hedef kitlenin yaş grubunu önemsemelerine, hitap ettiği kitlenin neyi neden niçin almak istediğini anlamalarına ve ona uygun pazarlama stratejileri geliştirmelerine sebebiyet vermiştir. Tüm kuşakların kendine özel yaşam tarzları; değer, tutum ve inançları; yaşadıkları ekonomik, politik ve tarihi olaylar ile edindiği deneyimleri satın alma kararlarını etkilemektedir. İşletmeler birçok kuşak ile ilişki içerisinde olup onları ürün veya hizmet satın almaları için ikna etme çabaları sarf etmektedir. Dolayısıyla işletmeler, her kuşağın özelliklerini ayrı ayrı analiz edebilmeli ve hitap ettiği yaş grubuna uygun pazarlama stratejileri geliştirebilmelidir.

Genel olarak kuşaklarda tüketim olgusu incelendiğinde Babby Boomers'lar savaş ve kıtlık sonrası dönemin kuşağı oldukları için tüketim olgusuna akılcı bir şekilde yaklaşmışlar, kitlesel pazarlamaya uygun olarak tatmin oldukları ürün veya hizmete karşı sadakat duygusu geliştirmişlerdir. Bunun yanında Babby Boomers'larda pazarlamanın belirlediği tek yönlü tüketim olgusu hakimdir.

Babby Boomers tüketicileri diğer insanlar ile iletişim kurmalarını sağlayacak, yaşamlarını zenginleştirecek ve dünyanın nimetlerinden yararlanmalarına imkan tanıyacak ürünleri satın almayı tercih etmekle birlikte toplumsal katkılardan ve amaçlı faaliyetlerden en fazla tatmini elde etmektelerdir. Dinsel inançlara önem veren Babby Boomers'lar satın aldıkları ürünlerde yenilikçi ve özel marklara daha az itibar etmektedir. Satın alacakları ürün veya markanın garantisine, ürünün geçmişine, kullanım kolaylığına ve güvenilirliğine daha fazla itibar etmektelerdir. Herhangi bir promosyonlu ürün ile karşılaştığında ilk olarak satın alma faaliyetinde bulunup daha sonra bu satın alma eyleminin etki ve sonuçlarını düşünmektelerdir (Bakırtaş, vd.,2016:68).

$\mathrm{X}$ kuşağı, ürünün fonksiyonel özelliklerinin ötesinde duygusal bir bağ kurduğu marka ile ilişkilerin etkisinde kalarak markaya göre kimliğini şekillendiren ilk kuşak olma özelliğine sahiptir. Geleneksel değerlere bağlı olan X kuşağı, hem 
akla hem de duyguya dayalı davranış sergileyen bir tüketici profili oluşturmaktadır (Kotler, vd.,2011: 42). X kuşağı üyeleri pazarlamaya farklı bir toplumsal boyut kazandırmak isteseler de bunu başaramamıştır ve pazarda pazarlamacı uygulamalarının esas alındığg tek yönlü bir tüketim olgusu hakim olmuştur.

$\mathrm{X}$ kuşağı mal mülk edinme ve alışveriş ile ilgili kaygılar taşıyan bir nesildir. Küçük yaşlardan itibaren alışveriş merkezleri ile karşılaşan X kuşağı üyeleri, ev ve okul dışında zamanlarının büyük bir kısmını alışveriş merkezlerinde geçirmektedir. Dolayısıyla alışveriş merkezlerinde zaman harcayan bireylerin amaçları para kazanıp ürün satın almaktır. X kuşağı ciddi anlamda televizyon izleyen bir topluluk olup kablolu televizyon ile tanışan ilk kuşaktır. Çok sayıda reklama maruz kalmaları ile birlikte alışveriş ve para ile ilgili kaygıları bu kuşağın pazarlama ve tanıtımlara yönelik tutumlarını etkilemektedir (Bakırtaş, vd.,2016: 67)

Gerçek kimliğini kendi rızasıyla tüketici kimliğine dönüştüren Y kuşağı, tüketim ile anılan ilk kuşak olma özelliğine sahiptir. Bu kuşak üyerleri, piyasada hâkimiyetin tüketiciye geçmesini sağlayarak tüketim toplumunu şekillendirmektelerdir. Kendine ait kararları tek başına veren, internetin sağladığı kolaylık ile alışveriş tutkunu olan, tüketimi eğlenceli bir oyun gibi gören, mobil iletişim araçları ile mevcut bilgi ve uygulamaları takip eden, pazarlamacıları haklarını bilen ve gerek görüldügünde hesap soran aktif bir tüketici kitlesidir. Dürüstlükten uzak, şeffaf olamayan ve hesap vermekten kaçınan pazarlamacılar Y kuşağı tarafından sosyal medyada belirlenerek kırmızı listeye alınmaktadır. $\mathrm{Bu}$ nedenle pazarlamacılar tüketicilere karşı dürüst olmalı, ahlak ve sorumluluk ilkelerine bağlı kalarak tüketicilere ulaşmalıdır. Y kuşağı, kendisini tüketim nesnesi haline getirerek kendisine ve topluma karşı yabancılaşmıştır. Bu durumdan kurtularak insani değerlerine tekrar kavuşmak isteyen Y kuşağı, kişisel ve kurumsal yapılarda ahlak ve sorumluluk olgularının üzerinde önemle durmaktadır. Tüketimin bir sınırı olmalı, pazarlamacılar da bu sınır içerisinde hareket etmeleri gerektiğini belirtmektelerdir.

Kendi kredi kartına sahip şanslı bir azınlık dışında olan Z kuşağı ise her konuda kişiselleşmiş kendine özgü imajı olan tüketici grubunu oluşturmaktadır. Tüketim eylemini kendileri gerçekleştiremese de, aile bireyleri tüketim kararlarında 
etkin rol aldıkları için pazarlamacılar tarafından önem verilen bir kuşaktır. Eğitim ve ekonomik açıdan ise diğer kuşaklara nazaran daha donanımlı olduklarından dolayı istedikleri ürünü anında almak, anında tüketmek ve sonrasında bir başka tüketim eylemine yönelmek istemektelerdir (Altuntuğ, 2012: 208-209).

Genellikle ebeveynlerin tek çocuğu oldukları için piyasaya çıkan yeni bir teknolojik ürünü hemen satın alma eğilimi sergileyen aynı zamanda kullanmakta zorlanmayan $\mathrm{Z}$ kuşağı, yakın geleceğin en büyük tüketici gurubunu temsil etmektedir. Bu kuşak üyeleri diğer kuşaklara göre farklı bir tüketici profili çizmekle birlikte tüketim davranışları incelendiğinde bireylerin kendilerine has bir imaja sahip, özgün ürünleri tercih etmekte olduğu gözlemlenmektedir. Bu yüzden işletmelerin $\mathrm{Z}$ kuşağına ulaşmak için farklı stratejiler geliştirmeleri gerekmektedir. Çok kolay ve sık sık marka değiştirebilen Z kuşağının marka sadakatleri ise diğer kuşaklara nazaran oldukça düşüktür. Ayrıca kullandıkları ürünler hakkında bilgi ve deneyimlerini sosyal medyada üzerinden paylaşma eğilimleri diğer kuşaklara göre çok daha yüksektir (Bakırtaş, vd., 2016: 70-71)

Farklı yaş gruplarındaki bireylere hitap etmek isteyen pazarlamacılar değişik görüntü ve dil kullanmaları gerekmektedir. Bu nedenle de her yaş grubuna özel farklı kampanyalar geliştirmektelerdir. Örneğin; Norelco markası tıraş makinesi ürünlerini genç erkek müşterilerin yaşlı erkek müşterilerine nazaran daha az kullanma eğilimi sergilediklerini gözlemlemiştir. Firma hem genç erkek müşterilerinin 1slak tıraş yerine elektrikli tıraş makinasına geçmelerini sağlamak hem de yaşlı erkek müşterilerinin kendi markalarına olan sadakatini korumak amacıyla iki çatallı çift yönlü tıraş bıçağı geliştirerek her iki müşteri yaş grubuna hitap etme girişiminde bulunmuştur. Speedrazor adlı ürünleri için 18-35 yaş arası erkekleri hedef alarak reklamlarını televizyonlarda geç saatlerde yayınlamış, dergide ise onlara hitap eden magazin dergisi olan GO ve Details dergilerinde yayınlamıştır. Üç başlı tıraş bıçağını ise 35 yaş üstü erkek tüketiciler için geliştirmekte olup ürün tanıtımı için daha yaşlı kesime hitap eden reklamlarda yayınlamışlardır (Solomon, 2013: 523).

Dünyada yaşanan ekonomik, politik, sosyal ve tarihsel önemli olaylar, küresel değişim, sürekli gelişen pazar tüketicilerin satın alma davranışlarını etkilemektedir. Pazarın sürekli gelişmesi tüketicilerin, her geçen gün değişik taleplerde 
bulunmalarına ve farklı ürün veya hizmet grubuna yönelmelerine sebep olmaktadır. Pazarlamacıların tüketici istek ve ihtiyaçlarını karşılayarak onları tatmin etmeleri ise gün geçtikçe zor bir hal almaktadır. Bu durumda işletmeler pazarda tutunmaları ve rakiplerinden üstünlük sağlamaları için hitap edeceği kitlenin yaş grup aralığını önemsemeleri, kuşak analizi ederek hedef kitlenin özelliklerine yönelik pazarlama stratejileri geliştirmeleri gerekmektedir.

\section{Y KUŞAĞININ ÖZELLIKLERİ}

Y kuşağı üyeleri teknoloji devrinde doğdukları için teknolojik ürünlere olan yatkınlıkları, bilgiye çok çabuk ulaşabildikleri için fikir ve düşüncelerinde özgür olmaları, eğitim hayatlarında ise yüksek beklentilere sahip olmaları bu kuşağın diğer kuşaklardan farklı bir şekilde incelenmesi gerektiğini ortaya koymaktadır (Okan ve Yalman, 2013:140). İşlerini çok daha iyi yapabilmek için hayatlarının her anında teknolojinin imkânlarından sonuna kadar yararlanan Y kuşağı, birçok teknolojik aletlere sahip olup 7/24 bu aletleri kullanmaktadır. Ayrıca bu kuşak üyeleri, SMS ve e-posta ile iletişim kurmaktan ziyade yüz yüze iletişimi, geleneksel sunum tekniklerinden ziyade online teknolojileri tercih etmektedir (Ağırdır, 2013: 1).

Genç, zeki, özgürlüklerine düşkün ve günün büyük bir bölümünde teknoloji ve medya ile iç içe olan Y kuşağı için yaşamlarını rahat bir şekilde sürdürmeleri büyük önem taşımaktadır. X kuşağından en üstün oldukları alan olan teknoloji, Y kuşağı için hayatlarının vazgeçilmez bir ögesi haline gelmiştir. Hızlı tüketmeyi seven bu kuşak üyeleri, genel olanı değil şahsa özel olanı tercih etmektedir ve en önemli özelliklerinden bir tanesi de girişimcilikleridir (Yaşa ve Bozyiğit, 2012: 33). Y kuşağı girişimcilik ve yaratıcılık ruhlarını kendi fikirlerini ve kendi işlerini kurarak hayata geçirmeyi hedeflemektedir. Ekonomi ve Araştırma dergisine göre kendi şirketlerini kurmak isteyenlerin bu kuşak içerisindeki oranı \%45'tir. Firmalarda çalışanlar ise bu yeteneklerini kullanmak ve bunları kullanabilecek ortamı yaratmak istemektelerdir. Dikte edilmiş, başka kişiler tarafından konulmuş kuralların uygulayıcısı olmak bu kuşak üyelerine göre değildir. Onun yerine bu kuralları koyan, değiştiren, yenileyen kendileri olmak istemektelerdir (Acılıoğlu, 2017: 38). 
Y kuşağı çalışanları kariyerlerinde zorlu işler ile karşılaşacağı ve kendilerini bu zorlu işler ile geliştirebileceği düşüncesine sahiplerdir. Sıkıcı, zevk almadığı bir işte çalışmak yerine zorlu bir iş seçimine gitmekte ve beklentileri karşılanmadığ sürece bir başka işe geçme eğilimi sergileyebilmektelerdir. Çalıştıkları işte terfi etme veya kendilerini geliştirme olanağı bulamadıkları takdirde işten ayrılma düşüncesine sahip olup isteklerine uygun bir iş bulana kadar işlerini değiştirme yoluna gitmektelerdir. İşten ayrılma veya iş değiştirme fikrine önceki kuşaklardan daha yatkınlardır (Yüksekbilgili, 2013: 345)

Y kuşağı üyeleri sadece elindeki işe odaklanmak yerine aynı anda farklı işlere de yönelerek hepsini eğlenceli bir şekilde sonuçlandırmayı tercih etmektedir. Toplantı esnasında aynı anda hem yöneticinin konuşmasını dinleyebilir hem de cep telefonu ile sosyal medyada arkadaşının paylaşımına yorum yapabilirler. Bilgisayarda, internet üzerindeki bir işi ile ilgili araştırma yaparken bir taraftan da Whatsapp'ta arkadaşları ile iletişime geçebilmektelerdir. Excel'de karışık bir analiz, müzik dinleyerek sonuçlandırabilmektelerdir. Tüm bunlar Y kuşağı üyelerinin işlerini sonuçlandırmalarında engel teşkil etmemektedir (Acılığlu, 2017: 46).

İnternet aracılığı ile uluslararası iletişimde bulunabilen Y kuşağı, ilk küresel müşteri grubunda yer almaktadır. Bu kuşak sosyal ağlar ile ürün tecrübelerini, bilgi ve fikirlerini paylaşıp karşılıklı iletişim halinde bulunurlar. Aynı zamanda kişisel ihtiyaç, istek ve seçimlerine özen göstermektelerdir. Y kuşağı tüketim odaklı olmakla birlikte karmaşık zevklere ve alışveriş eylemlerine sahip bir nesildir. Alışverişi sevme ve yüksek gelir düzeyine sahip olma özelliğinden dolayı perakende sektöründe bu etkinin büyük ölçüde devam edeceği öngörülmektedir (Okan ve Yalman, 2013: 140). Dünyaya gözünü açtıkları andan itibaren reklam ve meydanın etkisine maruz kalan, dolayısıyla kendinden önceki kuşakta yer alan anne ve babalarına nazaran marka bilincine daha çok sahip olan bir kuşaktır. Y kuşağı ile ilgili bir başka değinilen özellik ise bu kuşağın motivasyonunu sağlayan etkenlerin diğer kuşaklara göre farklılık göstermesidir. Bu kuşaktaki kişiler kazandıkları gelirden ziyade esnek çalışma saati, sosyal yardımlar gibi manevi yönden onları tatmin edecek unsurlara da önem vermektedir. Aynı zamanda yaptıkları işlerin onaylanıp taktir edilmesine, eğitim ve öğrenme olanaklarını da içeren bütünsel bir iş tatminine önem vermektelerdir (Başol ve Çetin Aydın, 2014: 4). 
Bir başka değinilmesi geren özellik ise Y kuşağının çevreye karşı duyarlı olmasıdır. Doğdukları andan itibaren hükümetlerin ve işletmelerin sosyal sorumluluk projesi başlığı altında doğal çevrenin korunması ile ilgi yaptıkları birçok yayının etkisi ile diğer kuşaklara nazaran çevre korunmasında daha duyarlı bir nesildir. Çünkü bu kuşağın yetişme evresinde küresel ısınma, ozon tabakasının delinmesi, iklimlerin değişmesi, doğal kaynakların gün geçtikçe azalması gibi çevre sorunları ortaya çıkmıştır. $\mathrm{Bu}$ yüzden $\mathrm{Y}$ kuşağı üyeleri doğal çevrenin korunma bilinci ile yetişmiştir (Başgözde ve Bayar, 2014: 124). Obezite ve AIDS gibi rahatsızlıkların ortaya çıktığı, doğal afet ve terörizmin korkutucu yeni gerçekler haline geldiği bir dönemde büyüyen Y kuşağı; sosyal ve çevresel farkındalığa sahip, insan ilişkilerine önem veren, eğitim seviyesi yüksek ve kariyer peşinde olan bir kuşaktır (Fettahlıoğlu ve Sünbül, 2015:32).

Tüm bunlardan yola çıkarak hızla değişen dünyada hayatlarını sürdüren $\mathrm{Y}$ kuşağ1 üyelerinin istek ve ihtiyaçlarını tatmin edecek yeni ürün ve deneyimlerin, pazarlamacılar tarafından tanımlanması gerekmektedir. Bu kuşak üyelerinin, ürün veya hizmette önem verdikleri unsur fiyattan ziyade değer, markanın refahı ve kimlikleri olduğu şeklinde yorum yapılabilir.

Bazı araştırmacılar tarafında ortak kabul edilen Y kuşağı üyelerinin temel özellikleri aşağıda belirtilmektedir (Yüksekbilgili, 2013: 346-347):

- $\quad$ Teknolojiyi yakından takip etmekte ve kullanmaktalardır.

- Genellikle çalışma hayatında kendilerini rahat hissettikleri işleri tercih etmektelerdir.

- $\quad$ Kendilerine karşı yüksek güven duygusuna sahiplerdir.

- Aynı anda birçok işi yapabildikleri anlamına gelen "Multitasting” özelliğine sahiplerdir.

- $\quad$ Özgürlüklerine aşırı derecede düşkünlerdir.

- $\quad$ En önemli ve vazgeçilmez iletişim alanı internettir.

- $\quad$ Kendi işini kurup kendi işinin patronu olmayı tercih etmektelerdir.

- Sabirsiz bir yapıya sahiplerdir.

- $\quad$ Sosyal iletişim ağlarını etkin ve verimli kullanarak iş yeri sınırlarında devamlı bağlantılı olmaya önem vermektelerdir. 
- Alışverişte online siteleri kullanmaktalardır.

- $\quad$ İş konusunda tatmin olmadıkları sürece işlerini kolayca değiştirebilmekte ve bu durumu hor görmemektelerdir.

- $\quad$ Sosyal sorumluluk bilincine sahiplerdir.

- Zor işlerin kendilerini geliştirebileceği düşüncesinde olup kariyerlerini o yönde şekillendirmektelerdir.

- $\quad$ Aile değerlerine önem vermektelerdir.

- $\quad$ Çok para kazanmak yerine hayattan zevk alıp keyifli bir yaşam sürdürmeyi tercih ederler.

- Gelecek kaygısı olmamakta ve bulundukları ana odaklanmaktalardır.

- İş hayatlarında kendilerine verilen görev ve sorumlulukları açık bir şekilde ifade edilmesine önem vermektelerdir.

- $\quad$ Esnek çalışma saatlerinden haz etmektelerdir.

- $\quad$ Farklı yerlerden aynı anda gelen bilgiyi kolayca kavramaktalardır.

- İyi bir dinleyici olan, iletişimleri güçlü olan, takım ruhuna önem veren, kendilerine emredilmesinden hoşlanmayan, teknolojik yeteneklere sahip kişilerdir.

Genel olarak incelendiğinde Y kuşağı; teknoloji çağında doğduğu için teknolojinin nimetlerinden fazlasıyla yararlanan bunun sonucunda hızlı düşünüp hızlı hareket eden ayrıca hızlı tüketim eğilimi sergileyen kişiler oldukları gözlemlenmiştir. Özgürlüklerine fazlasıyla düşkün, iş ve özel hayat arasındaki dengeyi iyi kurabilen, önceki kuşaklara nazaran daha kolay iş değiştirebilen, girişimcilik ruhu yükssek kişilerdir. Sorgulayıcı bir yapıya sahip olan Y kuşağı üyeleri aynı anda tek bir işe odaklanmak yerine birden fazla işe yönelebilen, eğlenceye önem veren, değişime ve öğrenmeye açık bir kuşak şeklinde özetlenebilir. Tüketici kitlesinin büyük bir bölümünü oluşturan, gelir seviyesi önceki kuşaklara nazaran yüksek olup güçlü harcamalar yapan, teknoloji ile iç içe olmalarından dolayı ürün veya marka ile ilgili bilgiye çok çabuk ulaşabilen, medya ve reklamların etkisi altında Y kuşağı çoğu pazarlamacı tarafından odak noktası olmaktadır. Bu yüzden firmaların pazarda aktif rol alabilmeleri veya olağan durumlarını koruyabilmeleri için tüketici kitlesinin önemli ve büyük bir bölümünü oluşturan Y kuşağının özelliklerini bilmeler gerekmetedir. Bu özellikler doğrultusunda onlara uygun stratejiler geliştirmeleri, kendilerine başarı sağlayarak rakiplerinden öne çıkarabilecektir. 


\subsection{Y KUŞAĞININ ADLANDIRILMASI}

Pazarlama ve medya dergisi olan “Advertising Age” dergisinin 1993 y1lında yayınlanan sayısında o çağdaki genç tüketicilerin tüketim alışkanlıklarını konu alan makalede "Y Kuşağı" tabiri kullanılmıştır. Daha sonra her şeyi sorgulayan düşünce yapılarıyla Türkçe anlamı "niçin?" olan "why" kelimesinden meydana getirilen kuşağa "Y" harfi verilmiştir. Bununla birlikte "Global Nesil", "Net Nesli", "Sonraki Nesil”, "Biz Nesli” gibi ifadelerde Y kuşağının adlandırılmasında kullanılmıştır (Kuyucu, 2014: 58).

\subsection{Y KUŞAĞININ YETISSTTIRILLME ŞEKLİ}

Y kuşağını kendileri ile arkadaş gibi gören X kuşağı, kendi ebeveynleri olan BabbyBoomers'ların tam tersi çocukları ile arkadaş gibi olma düşüncesini benimseyerek o düşünce doğrultusunda $\mathrm{Y}$ kuşağını yetiştirmişlerdir. Anne ve babaların kendilerini sadece ebeveyn olarak görmek istemediklerini belirten aile çalışmaları uzmanı Billingham, anne ve babaların çocuklarını severek onlara karşı güvendikleri bir arkadaşı gibi yanında olmak ve onlara yol göstermek istediklerini belirtmiştir. Ayrıca bu kuşak anne ve baba bağımlısıdır. Ebeveynlerinin kendilerine karşı yoğun ilgileri olması, Y kuşağı üyelerinin yüksek beklentiye sahip olmalarına ve özgüvenlerini arttırmaya fayda sağlamıştır (Twenge, 2009: 15).

Y kuşağ1 üyeleri; yer ve mekân sınırı olmaksızın alışveriş için bir çok alternatiflerin olduğu, sınırsız ve yaratıcı kredi firsatlarının sunulduğu, ürün ve hizmetlerin sosyal statü tanımında gittikçe önem kazandığı, reklam ve pazarlama bilgilendirme mesajların sürekli ve kolay bir şekilde istenilen yere ulaştırıldığı, eskiden sadece kadınların kullandığı ya da tam tersi erkeklerin kullandığı ürünlerin ortak kullanılabilir olduğu bir evrede yetişmiştir (Bakawell and Mitchell, 2003: 98).

Brigham Young Üniveristesi profesörü Larry Nelson ve arkadaşlarının yaptığ çalışmada; gençlerin, kariyerlerine başlamadan önce ya da aile kurmaya tam olarak kendilerini hazır hissetmeden harekete geçmeyen bir nesil olduğunu belirtmektedir. Araştırmaya göre, otuzlu yaşlara yaklaşmak veya otuzlu yaşlarda olmak tam anlamıyla bir yetişkin olmak anlamına gelmediği, yetişkinlik olgusunun yirmi beşlerden otuzlu yaşlara uzadığını ifade etmektedir. Bu kuşak üyelerine göre 
yaşın yetişkin olmak için bir anlam ifade etmediğini, ayrıca evlenip çocuk sahibi olma gibi ölçütler ile yetişmeye ve erken yetişkinlik olgusuna karşı gelen bir nesil olduğunı ifade etmektelerdir. Çalışmada Y kuşağının anne ve babalarına, onların iş ve evlilik arası ilişkilerine de değinilmiş olup ebeveynlerinin yaşamları boyunca tüm olayları aşama aşama gerçekleştirdikleri gözlemlenmiştir. Önce iş bulmuşlar, işinde sabır ve uzun vadede sadakat ile çalışmışlar hemen ardından çok hızlı bir şekilde evlenerek çocuk sahibi olmuşlardır. $\mathrm{Bu}$ durumların sonucu olarak Y kuşağı ebeveynlerinde mutsuz evlilik sonucu boşanmalar, ilerlemeyen kariyer planlarının olduğunu tespit etmiştir. Ebeveynleri gibi bir hayat yaşamak istemeyen Y kuşağı üyeleri yaşamlarının her evresinde düşünerek kararlar almış ve emin olduktan sonra uygulaya koymuşlardırdır (Özmen, 2016: 12)

\subsection{Y KUŞAĞININ HAYATA BAKIŞ AÇISI}

Singapur'daki GMP grubuna göre Y kuşağının başında olan patronlar daha fazla insan odaklı olurken Y kuşağının yer aldığı patronlar ise daha yetenekli davranmak istemektedir. Bu kuşak, liderliğin dengeli ve esnek olmasını istemekle birlikte yaptıkları işte deneme ve yanılma yoluna giderek işleri kendi yöntemleri ile yapma taraftarlarıdır. Y kuşağı, diğer kuşaklara göre farklı motivasyon ve beklentiye sahiptir. Bu kuşak bir takım parçası olarak çalışmaya hazır olup daha esnek davranışlar sergilemekte aynı anda çok görevi üstlenebilmektedir. Her ne kadar esnek bir yapıya sahip olsalar da yönergeye uyma eğilimi göstererek denetçilerin rehberlik etmesini istemektelerdir (Aktan, 2017: 37).

Y kuşağı, önceki kuşaklar ile aralarında en çok farkın olduğu bir kuşaktır. Hayata bakış açıları ile ilgili 2015 yılında Türkiye genelinde 15 bin katılımcı ile gerçekleştirilen TGI 2015 çalışması sonbahar verileri aşağıdaki tabloda gösterilmiştir (Marketing Türkiye, 2016: 85). 
Tablo 5 TGI 2015 Y Kuşağı Verileri

\begin{tabular}{|c|c|}
\hline Yaşam Biçimi Cümleleri & Y Kuşağı \\
\hline Çocuklar özgürce kendilerini ifade edebilmeli & $\% 68$ \\
\hline İyimser bir kişiyim & $\% 66$ \\
\hline Öğrenmenin yaş1 yoktur & $\% 64$ \\
\hline İnsanlar beni olduğum gibi kabul etmeli & $\% 62$ \\
\hline Uygun bulmadığım firmalardan ürün almam & $\% 53$ \\
\hline Şirketlerin iş ahlakına uygun hareket etmesi önemli & $\% 51$ \\
\hline Topluma bir şeyler veren şirketlerden ürün almaktan hoşlanırım & $\% 50$ \\
\hline $\begin{array}{l}\text { Çocukların sorumluluğu ve ev işleri eşler arasında eşit olarak } \\
\text { paylaşılmalı }\end{array}$ & $\% 49$ \\
\hline Düşündüğüm şeyin insanların kızdıracağını bilsem dahi söylerim & $\% 48$ \\
\hline Bir gün kendi işimi kurmak isterim & $\% 48$ \\
\hline Bir gün kendi işimi kurabileceğimden eminim & $\% 35$ \\
\hline
\end{tabular}

Kaynak: Marketing Türkiye, 2016/2: 85

\subsection{Y KUSSAĞININ PAZARLAMADAKİ ÖNEMI}

Firmalar, 2018 yılından itibaren önceki kuşaklara nazaran yüksek harcama gücüne sahip ve 2025 yılı itibari ile çalışan nüfus sayısının yüzde 70'ini kapsayacağı düşünülen Y kuşağı üyelerinin davranış ve tutumlarını göz önünde bulundurarak kendilerini yeniden biçimlendirme yoluna gitmektedir. Geçmişten günümüze en eğitimli kuşak olan Y kuşağı, teknolojinin nimetlerinden sınırsız bir şekilde yararlanarak kolayca birçok bilgiye ulaşabilmenin verdiği gücü arkasına almaktadır. 
Dolayısıyla her bir firmanın hedef pazar olarak Y kuşağının istek ve ihtiyaçları üzerinde önemle durması gerekmektedir (Bloomberg Businessweek 2015: 1).

İki yıl önceki verilere göre, dünya nüfusunun 7 milyarından 1.8 milyarını $\mathrm{Y}$ kuşağı oluşturmaktadır. Türkiye'de bu kuşakta yer alan kişi sayısı ise 25 milyon olmakla birlikte en küçüğü 16, en büyüğü 36 yaşında olduğu belirtilmektedir. Dolayısıyla Türkiye'de her üç bireyden birisi Y kuşağında yer almaktadır (Kuyucu, 2014: 59). Bu sonuçların pazarlama bakımından önemi ise, Y kuşağının alım gücüne sahip olmasının yanında tüketim açısından aile fertlerini etkileyebilme gücüne de sahip olması ve bunun artarak devam etmesidir (Türk, 2013: 81).

Büyük bir tüketici grubunu oluşturan Y kuşağının firmalar tarafindan özelliklerinin bilinmesi, satın alma tutum ve davranışlarının incelenmesi, istek ve ihtiyaçlarının analiz edilmesi hangi ürünü hangi koşulda tükettiklerini öğrenilmesi önem arz etmektedir. Firmaların bu doğrultuda Y kuşağının tutum ve davranışlarına uygun pazarlama stratejileri geliştirmeleri aynı pazarda aktif rol aldığı bir diğer firma ile aralarında rekabet avantajı sağlayacak veya mevcut durumunu korumalarına yardımcı olacaktır.

Y kuşağının her ne kadar bir markaya karşı sadakat duygusunun zayıf olduğu düşünülse de bu kuşağın bu denli konuşulması, analiz edilmesi, pazarlamacılar tarafından özel stratejilerin geliştirilmesi ve markaların peşinde koşmasının sebebi bulunmaktadır. $\mathrm{Bu}$ yaş aralığında seçilen marka veya ürünlere karşı sadakat duygusunun da fazla olması ve ilerleyen yaşlarda kullanılacak markaların bu yaş aralığında belirleniyor olmasıdır ( Türk, 2013: 83).

\subsection{Y KUŞAĞININ TÜKETIMM ALIŞKANLIKLARI}

Y kuşağının tüketime katılması ile birlikte piyasada hakimiyet tüketicinin eline geçmiştir. Bu kuşak üyeleri aklın ve tek doğrunun hakim olduğunu savunan postmodernist paradigmaya karşı çıkmıştır. Farklılıkların belirtilmesinden ve buna dayanan sınırsız bir tüketim anlayışının küreselleşmesinden yararlanarak kişiye özel, bireysel tüketime yönelmişlerdir (Altuntuğ, 2012: 208).

Reklam ve kişisel iletişim vasıtaları ile tüketici gruplarına ulaştırılan ürün ve hizmetlerden en fazla etkilenen kitleyi genç tüketiciler oluşturmaktadır. Genç 
tüketiciler hem günümüzün pazarını oluşturduğu hem de gelecekte yetişkin pazarını oluşturacağı için pazarda önem arz eden bir konumda bulunmaktadır. Kuşaklar üzerinde yapılan araştırmalara göre gençler anne ve babalarının bilgi birikimine hazır bir şekilde sahip oldukları için genç tüketicilerin oluşturduğu pazar, önceki kuşaklara nazaran daha güçlü ve farklıdır. Birçoğu kendilerinin belirlediği yaşam tarzını benimseyerek bireyselliği ön planda tutmaktadır. Ayrıca gençler arasında ün sahibi olan bir gruba üye olma ve o grubun yaşam tarzını benimsemeleride bir başka özellikleri arasındadır. Bu kuşak üyeleri önceki kuşaklara göre daha az marka sadakatine sahip kişiler olmakla birlikte yeni ve moda olan ürünleri daha çabuk benimsemektedir. Ürün hakkında bilgiye internet vasıtası ile çok çabuk ulaşabilmektelerdir (Tükel, 2014).

Pazarda son derece aktif olan Y kuşağı üyeleri sayı ve harcama gücü bakımından her yaşam evresinde önemli bir hedef kitlesi haline gelmektedir. $\mathrm{Bu}$ kuşak üyeleri ebeveynleri üzerinde muazzam harcama gücüne sahiptir ve tüketim odaklı bir toplumda yetişmiştir. Üniversite çağındaki bireyler ilk kez kendi başlarına olma özgürlüğünü yaşamaktadır, dolayısıyla bu durum tüketici olarak belirli istek ve ihtiyaçları olduğunu belirtmektedir. Üniversite eğitimi aldıklarından dolayı yüksek standartlarda yaşayan Y kuşağının; trend belirleyici rolü, pazardaki rolü ve gelişimi ayrıca pazarın büyüklüğü gibi nedenler ile pazarda en çok tercih edilen tüketici segmentlerinden biri olarak görülmektedir. Diğer kuşaklara nazaran harcamaları daha fazla olan Y kuşağı, benzersiz satın alma gücü ve cazibesinden dolayı pazarlamacılar tarafından büyük ilgi gösterilen tüketici toplumudur. Genel olarak Y kuşağı üyeleri marka bağımlılığ 1 yerine marka bilinirliliğine önem verdikleri için onlara, markaya karşı sadık olma anlayışını kabul ettirmek güç bir davranış olduğu belirtilmektedir (Noble, vd., 2009: 618).

Y kuşağı çoğu ürünün tekliğine dikkat etmekte olup bunu farklı olma üstünlüğü şeklinde algılamaktadır. Akran referans gruplarına çok duyarlı oldukları için belirli izlenim veya sosyal normları iletme konusunda güçlü bir istekleri vardır. Daha çok materyalist toplum ve kültürde büyüdükleri için statü araştırmaya yönelik tüketim eğilimi sergilemektelerdir. Zenginlik ve satın alma gücünü vurgulamalarının nedeni satatü ve prestij düşüncelerinin tüketim davranışlarını şekillendirmesidir. Örneğin, lüks restorant ve kafeler gibi göze çarpan ürün ve hizmetlerin yeni 
konseptlerine daha açık oldukları için o yerleri kendilerini ifade etmenin bir yolu ya da arzu edilen yaşamın sembolleri olarak görmektelerdir (Aktan, 2017: 35)

Yüksek cazibeye sahip ve göze çarpan ürünlerin tüketimi genç nesiller için genel bir özelliktir. Onlar bir ürünü kullanırken sadece kaliteli olduğu için değil aynı zamanda sosyal duruş nedeni ile kullanmaktadır (Phau and Cheong, 2009 akt, O'Cass and Siahtiri, 2013).

Tüketim konusunda diğer kuşaklara göre farklılık gösteren Y kuşağı üyeleri pazarlama stratejileri konusunda da diğer kuşaklara nazaran daha bilinçli oldukları için bir ürünü bu nesile pazarlamak çok kolay değildir. Kendilerine iletilen mesajlarda, insanların hassas oldukları şeylerden faydalanmaya çalışıldığını düşünürlerse o üründen tamamen soğumaktalardır. Dolayısıyla firmalar, sosyal sorumluluk projelerinde, pazarlama ve tutundurma stratejilerinde iletmek istedikleri mesaja özen gösterilmeleri gerekmektedir. Aile, arkadaş, eğlence ve beklentiler bu kuşak üyelerinin pazarlama konusundaki yaklaşımlarını ifade etmektedir (Solomon, 2006).

Y kuşağı üyelerinin tüketim alışkanlıkları genel olarak incelendiğinde diğer kuşaklara göre farklılıklar gösterdiği düşünülmektedir. Önceki kuşaklara göre yetiştirilme tarzı, yaşam koşulları, hayattan beklentileri, bilgi birikimleri farklılık göstermekle beraber bu durumların alışverişlerini etkilediği gözlemlenmektedir. Bir ürün veya hizmetten beklentileri farklılaşan bu grup üyelerinde marka bilinci çok iyi gelişmekte olup markaya olan sadakat ve bağımlılığı zayıflamaktadır.

\subsection{Y KUŞAĞININ SATIN ALMA DAVRANIŞI}

Y kuşağı, alışverişin basit bir satın alma davranışı olarak kabul edilmediği bir dönemde büyümüştür. Perakende ve ürün seçeneklerinin çoğaldığ1; alışveriş faaliyetlerinin yeni, eğlenceli ve deneyimsel boyut kazandığı bir kültürde yetişmiştir. Dolayısıyla Y kuşağının önceki kuşaklara göre farklı bir alışveriş tarzı geliştirmeleri kaçınılmaz bir gerçektir (Bakewell and Mitchell, 2003: 95). Teknoloji ve internetten çok fazla etkilenen Y kuşağının davranışları sıklıkla tartışılan ancak tam olarak anlaşılmamış, benzersiz ve etkili bir tüketici grubudur. Bu kuşak, seyahat etmeyi, materyalistik şeylerden çok deneyimler için para harcamayı tercih etmektedir. Y kuşağı, kendine özgü özelliklere sahip, ayırt edici markaları arzu etmekte ve bunu 
kendini ifade biçimi olarak kullanmaktadır. $\mathrm{Bu}$ tüketici grubunun geniş satın alma gücü ve teknolojik uzmanlığı, çevrimiçi perakendecilerin uzun vadede başarılı olup olmadıklarının belirlenmesinde büyük rol oynamaktadır. Y kuşağı, muazzam harcama gücüne sahip olmakla birlikte satın alımların çoğunlukla kıyafet, ayakkabı, takı, spor ekipmanları, eğlence, sağlık, kişisel bakım ve yiyecekler olduğu belirtilmektedir (Valentina and Powers, 2013).

Y kuşağının ürün satın almada karar verme süreci, ürün ve perakendeci bakımından farklılık göstermektedir. Ürün seçiminde daha duygusal davranış sergilerken alışveriş yerinin seçiminde daha rasyonel bir davranış sergilemektedir. Y kuşağı ürün seçimi hakkında karar verdikten sonra alışveriş yeri hakkında karar verdiği için düşük bir sadakat düzeyine sahiptir (Parment, 2013: 190).

Pazarlamacılar açısından bu kuşağı hedeflemenin bazı zorlukları vardır. $\mathrm{Bu}$ zorluklardan biri, Y kuşağı üyelerinin temel görüşü reddetme davranış1 sergilediklerinden dolayı onlar açısından markaların önemini yitirme tehlikesi, diğeri ise hızla değişen yaşam tarzları ve zevkleridir (Deneçli, 2015: 118). Diğer kuşaklara göre daha fazla marka tutkusuna sahip olan $\mathrm{Y}$ kuşağının bu şekilde yetişmesine imkân tanıyan ailelerini de etkilediği, onların tutum ve davranışlarını da yönlendirdiği gözlemlenmektedir. Kişisel istekleri sınır tanımamakta olan Y kuşağı, firmalar için önem arz eden bir pazarlama bölümünü oluşturmaktadır (Albayrak ve Özkul, 2013: 18).

Markalar ile beslenen bir dünyada büyüyen $\mathrm{Y}$ kuşağı, monoton metinsel bilgileri okumak yerine elektronik ortamda okuma yapmayı tercih etmektedir. Onlar için iletişim, videoların ve resimlerin taranması gibi görsel uyaranları içermelidir. Bir ürünün sunumunda yapılan küçük değişiklikler Y kuşağının dikkatini çekerek ürüne olan ilgisini artırabilmektedir. Örneğin, eşyaların renklere göre gruplandırılması veya vitrin düzeni gibi. Y kuşağı teknoloji ve interneti erken yaşta tanıyan ilk kuşak olma özelliğinden dolayı bloglar oluşturma, müzik indirme, çevrim içi oyunlar oynama, çevrimiçi bankacılık kullanma, internette iş araştırması yapma, seyahat ederken konaklama amaçlı internetten rezervasyon yaptırma gibi birçok işini internet üzerinden yaparak önceki kuşaklardan çok daha farklı yaşam tarzına sahiplerdir. $\mathrm{Bu}$ davranışları alışverişlerine de yansıtmaktalardır ve sosyal medyada çevrimiçi 
mağazaları takip ederek çevrimiçi satın alma davranışı sergilemektelerdir (Petra, 2016: 39).

Y kuşağı ürün hakkında bilgi sahibi olup indirim ve promosyonlarını takip etmek amacı ile saatlerce çevrim içi araştırma yapmaktadır. $\mathrm{Bu}$ kuşak üyeleri genellikle günlerinin bir saatini perakende sitelerini inceleyerek geçirmektedir. Erkek ve kadınların ilgi alanı farklı olduğu için internet üzerinde ürün hakkında araştırma yaparken genellikle erkek tüketicilerin spor ürünlerine, bilgisayar ve elektronik aletlere; kadın tüketicilerin ise kozmatik, giyim, hediyelik eşya, çocuk ürünleri ve züccaciye gibi ürünlere yoğunlaştığı gözlemlenmiştir (Lanchman ve Brett, 2013: 1820). Y kuşağı alışveriş merkezlerinde gezinmeyi ise ürün satın almakdan ziyade akrabaları veya arkadaşları ile vakit geçirme gibi bir aktivite ve eğlence olarak görmektedir (Gilboa ve Vilnai Yavetz, 2010).

Y kuşağı üyeleri alışveriş yapacakları zaman aktif oldukları sosyal medyadaki grupları ve diğerlerinin görüşlerini merak edip arştırma yapmaktalardır. Kendi nesillerinden kendi yaş grubuna yakın ve güvendikleri en az 3 kişinin fikrini almadan önemli kararlar vermemektelerdir. Y kuşağı kadınları diğer kuşak kadınlarına göre alışverişi bir grup etkinliği şeklinde arkadaşlarıyla, eşleriyle ve akrabalarıyla iki kat daha sık yapmaktadır. Sessizlik içerisinde bir tüketim yapmayıp gösterişli ve gürültülü bir yaşam tarzını benimsemektelerdir. Bu kuşağın çoğunluğu marka adlarına dikkat ederek satın alma eylemine geçmekte ve sosyal platformda marka seçimleri konusunda paylaşım yapmaktalardır (Sarı, vd., 2016:92).

Y kuşağının aktif sosyal medya kullanımı, pazarlamacılara bu tüketicilere kolayca ulaşma firsatı vermektedir. E-WOM, sosyal medya grupları ve çevrimiçi reklamcılık gibi sosyal medya pazarlama faaliyetleri, Y kuşağı tüketicileri arasında marka ve ürünlerin tanıtımı üzerinde büyük bir etkiye sahiptir. Y kuşağı üyeleri, satın alma niyetlerini etkileyen sosyal medya aracılığı ile bir ürün veya bir markayla ilgili deneyimlerini paylaşma eğilimi göstermektelerdir (Özçelik, 2015: 51).

Y kuşağının satın alma davranışları araştırıldığında, büyük bir bölümünün Facebook ve Instagram aracılığı ile ulaştığı çevrimiçi perakende satıcılarından alışverişlerini gerçekleştirdikleri sonucuna varılmıştır. Satın alma davranışlarını etkileyen faktörler araştıııldığında ise Y kuşağının satın alma davranış sürecinde 
algıladıkları güven ve saygı pozitif etkiye sahip iken algıladıkları kullanışlılık negatif bir etkiye sahip olduğu belirtilmektedir. Y kuşağı tarafından algılanan risk derecesi ise çevrimiçi satın alma davranışı üzerinde negatif etkiye sahip olmadığı belirtilmektedir. Y kuşağına yönelik pazarlama stratejilerin oluşturulması, işletmeler için kısa vadede bilinirliliğini ve satışlarını pozitif yönde etki etmektedir. Gıdadan tekstile, telekomdan teknolojiye birçok markanın Y kuşağını elde etmek için ciddi çaba sarf ettiği gözlemlenmektedir. Bu çabalar genellikle sponsorluk olarak yansıdığı ve markaların üniversite kampüslerini hedef almaları şeklindedir. İşletmeler; yarışmalardan eğitimlere, konserlerden konferanslara kadar kampüs içinde yer alan birçok etkinlikte bulunmak için birbirleri ile yarışmakta olduğu ve özellikle son yıllarda kantin giydirme yoluna başvurdukları görülmektedir. (Bakırtaş, 2016: 6466).

Yeni ürün, yeni marka kavramlarına daha yatkın olan, ürün yelpazesinin çok geniş olduğu bir dönemde yetişen Y kuşağı üyeleri teknolojiyi çok iyi kullandıkları için ürün ile ilgili çok fazla biliye kısa zamanda ulaşmaktadır. Alışverişleri daha çok arkadaşları ile sosyal aktivite olarak gören, bir ürünü fiyatından veya kalitesinden değil de o ürünün kendi üzerindeki sosyal duruşundan dolayı kullanan bu kuşak üyelerini anlayabilmek firmalar için büyük önem arz etmektedir. Gün geçtikçe artan rekabet koşullarında firmaların aktif pazarda rol alması veya mevcut durumlarını koruyabilmesi için hayata tüketicilerin gözünden bakabilmeleri gerekmektedir. Pazarın büyük bir bölümünü kapsayan Y kuşağı üyelerinin özelliklerinin çok iyi bilinmesi, bir ürün veya hizmetten beklentilerinin saptanması ve bu doğrultuda pazarlama stratejileri geliştirmesi firmaları rakiplerinden öne çıkaracağ düşünülmektedir.

\subsection{Y KUŞAĞININ ETNOSENTRİK EĞİLIMLERİ}

Küreselleşen pazarın ve uluslararası rekabetin etkisiyle firmalar çok kültürlü bir alanda rol almaya zorlanmaktadır. Teknoloji ve medya ile yakınlaşmayı sağlayan küreselleşme; tüketicilerin yaşam tarzları, ihtiyaçları ve algılarının bağdaşıklaşmasına neden olduğu bir tartışma konusu olarak yer almaktadır. Pazarın büyümesi firmaların yayılmasına imkan tanıyıp kazanacakları pazar bilgisi ile önemli bir rekabet avantajı sağlayacağı vurgulanmaktadır. Yerel ve uluslararası anlamda 
yüksek kaliteye sahip ürünlerin tüketicilere düşük maliyet ile sunulmasının gerekliliği, kendi ekonomisini güçlendirmeye çalışan ülkelerin uyguladıkları politikalar ve tüketicilerin bazı ülke ürünlerine yönelik olumlu veya olumsuz duygu beslemelerinin yanında firmaların uyguladığ anlamda şekillenmesine olanak tanımaktadır (Kayabaşı vd., 2016: 32).

Tüketiciler tarafından bir ürünün oluşturulduğu veya üretildiği düşünülen ülke, Ulusal imajlara dayalı olarak farklı algılamalar taşıdıklarını ve bu algılamalar tüketicilerin tutumlarını, satın alma niyet ve davranışlarını etkilemekte olduğu belirtilmektedir (Parts and Vida, 2011: 355).

Sertoğlu ve Çatlı tarafından 2017 yılında yapılan "Genç Tüketicilerin Yabancı ve Türk Ürünlerine İlişkin Tutum ve Tüketici Etnosentrizm Düzeylerini Belirlemeye Yönelik Bir Araştırma” çalışması incelendiğinde katılımcılar, Türk malı ürünleri satın alarak yerli ekonomiye katkı sağladıkları görüşündelerdir. Ayrıca ithalatın yasaklanmasının ve yabancı ürün satın almanın doğru bir davranış olmadığı fikrini desteklemeyip, Türkiye'de tedarik edilemeyen ürünlerin ithal edilebilir olamsı düşüncesindelerdir. Yabancı ürün tercih edilmesinde en büyük etken olarak teknolojinin ardından kalitenin geldiği tespit edilmektedir. Yabancı ürünler için ülke menşeinin güvenilirliği en olumsuz değerlendirilen özellik olarak yer almaktadır. Yerli ürünler için ise tam tersi, en olumlu değerlendirilen özellik ülke menşei güvenilirliği olup teknolojik özellik ve verilen paraya değmesi nispeten daha olumsuz değerlendirildiği gözlemlenmiştir (Sertoğlu ve Çatlı, 2017).

Kocaeli Üniversitesi İktisadi ve İdari Bilimler Fakültesi öğrencilerine uygulanan, genç Türk müşterilerinin satın alma davranışlarını ve etnosentrik eğilimlerini inceleyen bir başka çalışmada; öğrencilerin yerli veya yabancı ürün tercih ederken fiyatların makul olması ve ürünün kaliteli olmasına dikkat etmekte olduğu sonucuna ulaşılmıştır. Tüketiciler pazarın küresel etkisi altında kalmaya devam etmekte ve satın alma davranışlarında etnosentrik eğilimlerle hareket etmediği ortaya konulmaktadır. Satın alma işlemi gerçekleştirirken tüketiciler yüksek kaliteli, fiyat vb. değişkenlere önem vermeyi tercih etmektedir. Çünkü çağımızda tüketiciler teknolojik gelişmeler ile bilgiye daha hızlı erişebilmekte ve bu nedenle ürünlerden beklentileri de artmaktadır (Candan, vd., 2008). 
Küreselleşme ile birlikte ulusal sınırların ortadan kalkmasıyla tüketiciler gün geçtikçe farklı ülkelerin ürünlerine maruz kalmakta, firmalar ise rekabet piyasasında ayakta kalmaya çalışmaktadır. Tüketici topluluğunun büyük bir bölümünü oluşturan Y kuşağının yerli ve yabancı ürünlere karşı algı ve tutumlarının incelenmesi o pazara girecek firmaların nasıl bir yol izleyeceğine dair ipucu vererek rekabet avantajı sağlayacağı söylenebilir. 


\section{ÜÇÜNCÜ BÖLÜM}

\section{Y KUŞAĞININ ETNOSENTRIK EĞILIMLERE GÖRE YERLİ VE YABANCI ÜRÜNLERE KARŞI SATIN ALMA DAVRANIŞI ÜZERINNE AFYONKARAHISAR İLINNDE BIIR UYGULAMA}

\section{ARAȘTIRMANIN ÖNEMİ}

Küreselleşme ile ulusal sınırların ortadan kalkması ve buna paralel olarak teknolojinin yaygınlaşması tüketicilere geniş bir ürün yelpazesi sunmakla birlikte istedikleri ürüne kolayca ulaşma imkânı tanımaktadır. Tabi bu durum firmaların girecekleri pazarda bazı problemler ile karşılaşmasına neden olabilmektedir. Bu problemlerden bir tanesi de tüketici etnosentrizmidir. Yabancı bir firmanın, girmek istediği pazardaki tüketicilerin etnosentirik eğilim düzeyleri yüksek ise bu durum firma için hedef pazarda büyük bir engel teşkil edebilmektedir. Çünkü etnosentrik eğilim düzeyleri yüksek olan tüketiciler, yabancı ürünleri kendi ülkeleri için bir tehdit unsuru olarak görmektedir. Ürünlerini değerlendirirken de bunu tutum ve davranışlarına yansıtmaktadır. Bu sebeplerden dolayı başka ülkelerin pazarına girmek isteyen yabancı firmalar, o pazarın etnosentrik eğilim düzeylerini bilmeleri çok önemlidir.

Sürekli değişen ve gelişen dünyada tüketicilerin de istek ve ihtiyaçları sürekli değişmektedir. Buna bağlı olarak pazarlamacıların tüketicileri anlayabilmeleri, onların istek ve ihtiyaçlarına cevap vererek tatmin edebilmeleri gün geçtikçe zor bir hal almaktadır. Bu yüzden daha tutarlı bir pazarlama stratejileri oluşturmak isteyen firmalar tüketicileri, yaş aralıklarına göre bulundukları kuşak bazında keşfetmeye çalı̧̧maları kendileri için avantaj sağlayacaktır. Bu çalışma, gerek kitle bakımından gerekse harcama gücü bakımından pazarda önemli bir konuma sahip olan 1980 ile 2000 yılları arasında doğan Y kuşağı üyelerinden oluşmaktadır. Günden güne artan rekabet koşullarında firmaların rakiplerinden önde olabilmesi veya pazardaki mevcut durumunu koruyabilmesi için farklı pazarlama stratejileri geliştirmeleri gerekmektedir. Pazarın büyük bir bölümünü kapsayan Y kuşağı üyelerinin yerli veya yabancı ürünlere karşı bakış açılarının analiz edilmesi, bu kitleyi hedef alan yerli/yabancı firmalar açısından etnosentrizmin muhtemel olumlu veya olumsuz etkilerini kendilerince değerlendirip ona uygun pazarlama stratejileri geliştirmeleri 
bakımından önemli bir bilgi kaynağı olacağı varsayılmaktadır. Ayrıca literatürde kuşak bazında etnosentrik eğilimlerin ölçülmesi ile ilgili sınırlı sayıda çalışma bulunmakta olup gelecekte yapılacak olan akademik çalışmalara kaynak olması bakımından önem arz etmektedir.

\section{ARAŞTIRMANIN AMACI}

$\mathrm{Bu}$ araştırmanın amacı Afyonkarahisar ilinde yaşayan $\mathrm{Y}$ kuşağı üyelerinin yerli ve yabancı ürünlere karşı etnosentrik eğilim düzeylerini belirleyerek market, mağaza ve pahalı-lüks olarak kategorize edilmiş ürünlere karşı tutum ve davranışlarını inceleyip etnosetntrizm ile ilişkisine bakmaktır. Ayrıca Y kuşağın demografik özellikleri ile etnosentrik eğilimlere göre satın alma davranışları arasındaki ilişkiyi incelemektir.

\section{ARASTIRMA YÖNTEMI}

Araştırma yöntemi kapsamında araştırmanın ana kütlesi, örneklem seçimi, veri toplama yöntemi, anket formunun hazırlanması, test edilmesi, araştırmada kullanılan ölçekler ve istatistiksel yöntemler hakkında detaylı bilgiler verilmiştir.

\subsection{ARAŞTIRMANIN ANA KÜTLESİ VE ÖRNEKLEM SEÇİMİ}

$\mathrm{Bu}$ araştırmanın ana kütlesi Afyonkarahisar ilinde yaşayan, 1980 ile 2000 yılları arasında doğan Y kuşağı üyelerinden oluşmaktadır. 2017 yılı Türkiye İstatistik Kurumu verilerine göre Afyonkarahisar'1n nüfusu 715.693 olduğu belirtilmektedir (TUİK). Bu nüfusun 354.438'i erkek, 361.255'i kadından oluşmaktadır. 1980-2000 yılları arasında doğan Y kuşağı sayısı 211.259 kişiden oluşmaktadır. Merkez nüfus ise 295.683 kişiden oluşmakla birlikte çalışmanın ana kütlesini Afyonkarihisar'ın merkezinde yaşayan Y kuşağı üyeleri oluşturduğu için merkez nüsüfta yaşayan $Y$ kuşağı üyeleri baz alınarak örneklem seçimi yapılmıştır. Bu rakamda takribi olarak 87.280 kişi olduğu belirlenmiştir. Bilimsel bir araştırma için evren büyüklüğü 100.000 ve üzeri olduğu durumlarda kabuledilebilir örnek büyüklüğü 384 olarak belirtilmektedir (Altunışık, vd.,2010:135). Çalışmada amaca ulaşabilmek ve Afyonkarahisar ilinde sonuçlarını genelleyebilmek için 500 kişi sayısı yeterli olacağı öngörülmüştür. 


\subsection{VERİ TOPLAMA YÖNTEMI}

Araştımada veri toplama yöntemi olarak kolayda örneklem yöntemlerin arasında yer alan anket yöntemi kullanılmıştır. Araştırmanın ön çalışmasında, demografik özelliklerin eşit dağılımı esas alınarak Afyonkarahisar ilinde yaşayan 55 kişiye pilot uygulama gerçekleştirilmiştir. Araştırmada güvenilirliği tespit etmek amacı ile Cronbach Alfa katsayısı kullanılmıştır. Yapılan pilot çalışma sonucu anketin güvenilirliği ölçülmüş olup Cronbach Alfa değeri 0,85 bulunarak anket sorularının güvenilirliğine kanaat getirilmiştir. Anket ile veri toplama yöntemi olarak yüz yüze anket tercih edilmiş olup, verilerin büyük bir kısmı yüz yüze anket ve elden bırakılan anket metodu ile toplanmıştır. Çalışmada kullanılan anketler, Afyonkarahisarda yaşayan Y kuşağı üyelerine homojen bir şekilde dağıtılması ve örneklemin ana kütleyi temsilini arttırmak amacı ile Afyonkarahisar ilinin farklı yerlerlerinde (üniversite, hastahane, belediye binası, alışveriş merkezleri, kafeler, otomotiv sektörü, mermer sektörü, yerel işletmeler, park ve piknik alanları) dağıtılmıştır. Çalışma ilk olarak 500 kişiye uygulanmıştır fakat toplanan anketler içerisinde 118'nin eksik doldurma, rastgele doldurma, arka sayfasını doldurmama gibi sebeplerden analize dahil edilmemiştir. Bu yüzden 118 anket farklı Y kuşağı katılımcıları üzerine yeniden uygulanarak analize dahil edilmiştir.

\subsection{ANKET FORMUNUN HAZIRLANMASI}

Anket formu cevaplayıcıya hitaben yazılmış bir sunuş yazısına ilaveten 4 bölüm halinde düzenlenmiştir. Anket soruları 5'li likert ölçeği kullanılarak (1=Kesinlikle Katılmiyorum 2=Katılmıyorum 3=Karasızım 4=Katıliyorum 5=Kesinlikle Katılıyorum) hazırlanmıştır. 1. bölümde katılımcıların demografik özelliklerine ilişkin sorular yer almaktadır. 2. bölüm, 1998 y1lında Klein ve Ettenson çalışmasında kullanılan yerli ve yabancı ürünlere karşı ürün yargı ve satın alma niyetini ölçen sorulardan oluşmaktadır. Ayrıca menşei ülke etkisi çalışılan birçok araştırmada yer alan katılımcıların bir ürünü almadan önce ürün ile ilgili bilgi edinmek için hangi ülkede üretildiğini öğrenmek amacı ile etiketine bakma sıklığını ölçen sorulardan oluşmaktadır. 3. bölüm, market ürünleri (gıda, temizlik, kozmetik, kişisel bakım) daha çok gündelik hayatta kullandığımız kolay erişebileceğimiz, 
mağaza ürünleri (giyim, ayakkabı, aksesuar, çanta, beyaz eşya, ev elektroniği, mobilya küçük ev aletleri, oyun ve eğlence setleri) daha çok satın alma sırasında bizi düşündüren beğenmeli ürünler, pahalı ve lüks ürünler (otomobil, ev, pahalı elektronik ürünler, pahalı mobilyalar, sanatsal ürünler, mücevher, koleksiyon ürünleri) daha çok satın almadan önce üzerinde uzun süre düşündüğümüz kolay erişemediğimiz lüks ürünlerden oluşmaktadır. Katılımcıların yerli ve yabancı ürünlere karşı tutum ve davranışlarını kategorize edilmiş ürün grupları için değerlendirilmesi istenilen (Arı, 2007, Özmen, 2004) çalışmalarından uyarlanmış sorulardan oluşmaktadır. Son bölümde ise katılımcıların etnosentrik eğilim düzeylerini belirlemek amacı ile 1987 yılında Shimp ve Sharma tarafından Amerikalı tüketicilerin yabanc1 ürünlere karşı yerli ürün tercihlerindeki etnosentrik eğilim düzeylerinin belirlenmesi amacı ile geliştirilen aynı zamanda birçok araştırmada güvenilirliği ve geçerliliği test edilmiş Tüketici Etnosentrik Eğilim Ölçeği "CETSCALE (Consumer Ethnocentric Tendency Scale)" kullanılmıştır. Çalışmada kullanılan anket formu Ek -1 de gösterilmektedir.

\subsection{ARAŞTIRMADA KULLANILAN İSTATISTTIKSEL YÖNTEMLER}

Araştırma sonucunda elde edilen verilerin analizinde istatistiksel analizlerin yapılma aracı olan SPSS (Statistical Package for Social Sciences) for Windows Version 20.0 programı kullanılmıştır. Elde edilen veriler analiz edilirken frekans, ortalama, yüzde alma gibi yöntemler kullanılmıştır. Ölçeğin iç tutarlığını ve yapı geçerliliğini ölçmek amacıyla güvenilirlik ve faktör analizleri yapılmıştır. Uygun analiz türünün belirlenmesinde ilk kriter verilerin türüdür. Niceliksel verilerin normal dağılıma uygunlukları Kolmogorov Smirnov testi ve grafiksel değerlendirmeler ile sınanmıştır. Normal dağılım gösteren üç ve üzeri grupların için One-Way Anova Test kullanılmıştır. Niteliksel verilerin analizinde Pearson Ki-Kare Testi kullanılmıştır. Anlamlılık p <0.05 ve p <0,01 düzeylerinde değerlendirilmiştir 


\section{ARAȘTIRMA HIPOTEZLERI}

Araştırmada kullanılan hipotezler literatür taraması yapılarak kurulmuştur. Demografik özellikler ile etnosentrizm arasındaki ilişkiyi ölçen hipotezler Özmen (2004), Arı (2007), Armağan ve Gürsoy (2011), İşler (2013) çalışmalarından uyarlanarak oluşturulmuştur. Yerli/yabancı ürün yargısı ile etnosentrizm arasındaki ilişkileri ölçen hipotezler Arı (2007), Topçu (2014), Özmen (2017) çalışmalarından uyarlanarak oluşturulmuştur. Kategorize edilmiş ürün grupları ile etnosentrizm arasındaki ilşkileri ölçen hipotezler Arı (2007), Armağan ve Gürsoy (2011), Yapraklı ve Keser (2013), Sertoğlu ve Çatlı (2017) çalışmalarından uyarlanarak oluşturulmuştur. Menşe ülke etkisi ile etnosentrizm arasındaki ilişkiyi ölçen hipotez Özmen (2004), Arı (2007), İşler (2013), Sertoğlu ve Çatlı (2017) çalışmalarından uyarlanarak oluşturulmuştur.

Hipotez 1: Demografik özellikler ile etnosentrik eğilim düzeyleri arasında anlamlı bir ilişki vardır.

Hipotez 1.a: Etnosentrik eğilim düzeyleri, cinsiyete bağlı olarak farklılaşmaktadır.

Hipotez 1.b: Etnosentrik eğilim düzeyleri, medeni duruma bağlı olarak farklılaşmaktadır

Hipotez 1.c: Etnosentrik eğilim düzeyleri yurt dışına çıkma durumuna bağlı olarak farklılaşmaktadır.

Hipotez 1.d: Etnosentrik eğilim düzeyleri yaşa bağlı olarak farklılaşmaktadır.

Hipotez 1.e: Etnosentrik eğilim düzeyleri eğitim durumuna bağlı olarak farklılaşmaktadır.

Hipotez 1.f: Etnosentrik eğilim düzeyleri meslek gruplarına bağlı olarak farklılaşmaktadır.

Hipotez 1.g: Etnosentrik eğilim düzeyleri aylık gelir durumlarına bağlı olarak farklılaşmaktadır.

Hipotez 2: Yabanc1 ürün yargısı ve satın alma niyeti etnosentrik eğilim düzeylerine bağlı olarak farklılaşmaktadır.

Hipotez 3: Market ürünleri satın alma davranışı, etnosentrik eğilim düzeylerine bağlı olarak farklılaşmaktadır. 
Hipotez 4: Mağaza ürünleri satın alma davranış1, etnosentrik eğilim düzeylerine bağlı olarak farklılaşmaktadır.

Hipotez 5: Pahalı ve lüks ürün satın alma davranışı, etnosentrik eğilim düzeylerine bağlı olarak farklılaşmaktadır.

Hipotez 6: Yabancı ürün yargısı satın alma niyeti, menşe ülke etkisi önermelerine katılma kararına göre farklılık gösterir.

Hipotez 7: Etnosentrik eğilim düzeyleri, menşe ülke etkisi önermelerine katılma kararına göre farklılık gösterir. 


\section{ARAŞTIRMA BULGU VE YORUMLARI}

Y kuşağında yer alan katılımcılatın sosyo-demografik özellikleri, yabancı ürün yargı ve satın alma niyetleri, kategorize edilmiş ürün sınıflarına ilişkin tutum ve davranışları son olarak da etnosentrik eğilimleri, anket yöntemi ile toplanmasından sonra elde edilen verilerin analiz işlemi gerçekleştirilmiştir.

\subsection{Y KUŞAĞININ TEMEL KARAKTERISTIIK VE DEMOGRAFIKK ÖZELLİKLERINNE İLİŞKİN BULGULAR}

Y kuşağında yer alan 500 kişinin katılımıyla gerçekleştirilen araştırmada, katılımcıların cinsiyet, yaş, medeni durum, eğitim durumu, gelir, meslek, ve yurt dışında bulunma durumunun yer aldığı veriler aşağıdaki tablolarda gösterilmiştir.

Tablo 6 Cinsiyetlere Göre Dağılım

\begin{tabular}{|l|l|c|c|}
\hline \multicolumn{2}{|c|}{} & frekans & \% \\
\hline \multirow{2}{*}{ Cinsiyet } & Kadın & 211 & 42,2 \\
\cline { 2 - 4 } & Erkek & 289 & 57,8 \\
\hline Toplam & 500 & $\% 100$ \\
\hline
\end{tabular}

Y kuşağında yer alan katılımcıların cinsiyet dağılımları incelendiğinde, \%42,2'si kadın katılımcılardan, \%57,8'i erkek katılımcılardan oluştuğu için erkek katılımcıların kadın katılımcılara göre daha yoğun olduğu görülmektedir.

Tablo 7 Medeni Duruma Göre Dağılım

\begin{tabular}{|l|l|c|c|}
\hline \multicolumn{2}{|c|}{} & frekans & \% \\
\hline \multirow{2}{*}{ Medeni Durum } & Evli & 167 & 33,4 \\
\cline { 2 - 4 } & Bekâr & 333 & 66,6 \\
\hline Toplam & 500 & $\% 100$ \\
\hline
\end{tabular}

Y kuşağında yer alan katılımcıların medeni durumları incelendiğinde, \%33,4'ü evli, \%66,6'sı bekar katılımcılardan oluştuğu görülmektedir. Çoğunluğunun bekar katılımcılardan oluşma sebebi ise çalışma kapsamında yaş olarak 1980 ve 2000 yılları arasında doğan genç kesim ele alındığı için çoğunluğu daha yeni hayata 
atılmaya başlamış kişilerden oluşmaktadır. Evlilikten çok kariyere daha önem veren bir nesil olduğu için evlilik hedefleri arasında ilkini oluşturmadığı ilaveten ifade edilebilir.

Tablo 8 Mesleklerine Göre Dağılım

\begin{tabular}{|l|l|c|c|}
\hline \multicolumn{2}{|c|}{} & frekans & \% \\
\hline \multirow{5}{*}{ Meslek } & Memur & 56 & 11,2 \\
\cline { 2 - 4 } & İşçi & 41 & 8,2 \\
\cline { 2 - 4 } & Esnaf & 29 & 5,8 \\
\cline { 2 - 4 } & Serbest Meslek & 14 & 2,8 \\
\cline { 2 - 4 } & Özel Sektör & 112 & 22,4 \\
\cline { 2 - 4 } & Ev Hanımı & 33 & 6,6 \\
\cline { 2 - 4 } & Öğrenci & 152 & 30,4 \\
\cline { 2 - 4 } & Akademisyen & 33 & 6,6 \\
\cline { 2 - 4 } & İşsiz & 13 & 2,6 \\
\cline { 2 - 4 } & Diğer & 17 & 3,4 \\
\hline Toplam & & 500 & $\% 100$ \\
\hline
\end{tabular}

Y kuşağında yer alan katılımcıların meslek dağılımları incelendiğinde, çoğunluğun \%30,4 oranında öğrenci olduğu görülmektedir. Bunun sebebi olarak çalışma üniversite dışında alışveriş merkezlerinde, piknik alanlarında ve kafelerde uygulandığı için öğrencilerin yoğun olarak buralarda bulunmaları ayrıca artık kişilere bir üniversite mezunu olmak yetmediği günümüz zamanında okuma yaşının da arttığı söylenebilir. Meslek dağılımının ikinci sırasında ise \%22,4 oranında özel sektörde çalışanlar yer almaktadır. Buradan anlaşıldığı üzere çalışmada yer alan katılımcıların meslek dağılımı çoğunluktan azınlığa doğru öğrenci, özel sektör, memur, işçi, ev hanımı/akademisyen, esnaf, diğer, serbest meslek, işsiz şeklinde sıralandığ görülmektedir. 
Tablo 9 Yaşa Göre Dağılım

\begin{tabular}{|l|l|c|c|}
\hline \multicolumn{2}{|c|}{} & frekans & \% \\
\hline \multirow{4}{*}{ Yaş } & $\mathbf{1 9 - 2 2}$ Yaş & 129 & 25,8 \\
\cline { 2 - 4 } & $\mathbf{2 3 - 2 6}$ Yaş & 130 & 26,0 \\
\cline { 2 - 4 } & $\mathbf{2 7 - 3 0}$ Yaş & 100 & 20,0 \\
\cline { 2 - 4 } & $\mathbf{3 1 - 3 4}$ Yaş & 69 & 13,8 \\
\cline { 2 - 4 } & $\mathbf{3 5 - 3 8}$ Yaş & 72 & 14,4 \\
\hline Toplam & 500 & $\% 100$ \\
\hline
\end{tabular}

Çalışma 1980 ile 2000 yılları arasında doğan kişileri ele aldığı için yaş olarak kapsamı sınırlıdır. Bu kapsam da kendi arasında 5 gruba ayrılarak 19-22 yaş grubunda yer alan kişiler ile 35-38 yaş grubunda yer alan kişilerin etnosentrik eğilim düzeyleri arasında bir farklılık bulunup bulunmadığını belirlemek amaçalanmıştır. Y kuşağında yer alan katılımcıların yaşları incelendiğinde, \%71,8'ini 30 yaş ve altı oluşturduğu, \%28,2'sini ise 31 - 38 yaş arası oluşturduğu görülmektedir.

Tablo 10 Eğitim Duruma Göre Dağılım

\begin{tabular}{|l|l|c|c|}
\hline \multicolumn{1}{|c|}{} & frekans & \% \\
\hline \multirow{4}{*}{ Ĕ̆itim Durumu } & Ilköğretim Mezunu & 27 & 5,4 \\
\cline { 2 - 4 } & Lise Mezunu & 153 & 30,6 \\
\cline { 2 - 4 } & Ön Lisans Mezunu & 78 & 15,6 \\
\cline { 2 - 4 } & Lisans Mezunu & 198 & 39,6 \\
\cline { 2 - 4 } & Yüksek Lisans Mezunu & 25 & 5,0 \\
\cline { 2 - 4 } & Doktora & 19 & 3,8 \\
\hline \multirow{3}{*}{ Toplam } & 500 & $\% 100$ \\
\hline
\end{tabular}

Y kuşağında yer alan katılımcıların eğitim durumu incelendiğinde, \%39,6'sının lisans mezunu olduğu, çoğunlukla eğitimli katılımcılardan oluştuğu görülmektedir. Katılımcıların büyük bir kısmının 30 yaş ve altı olması ayrıca çoğunluğun öğrencilerden oluşması eğitim durumunun yüksek çıkmasına neden olabilir. 
Tablo 11 Aylık Gelir Durumuna Göre Dağılım

\begin{tabular}{|l|l|c|c|}
\hline \multicolumn{2}{|c|}{} & frekans & \% \\
\hline \multirow{4}{*}{ Aylık Gelir } & $\mathbf{1 5 0 0}$ TL ve altı & 183 & 36,6 \\
\cline { 2 - 4 } & $\mathbf{1 5 0 1 - 3 0 0 0}$ TL & 168 & 33,6 \\
\cline { 2 - 4 } & $\mathbf{3 0 0 1 - 4 5 0 0}$ TL & 72 & 14,4 \\
\cline { 2 - 4 } & $\mathbf{4 5 0 1 - 6 0 0 0 ~ T L}$ & 50 & 10,0 \\
\cline { 2 - 4 } & $\mathbf{6 0 0 0}$ TL ve üzeri & 27 & 5,4 \\
\hline Toplam & 500 & $\% 100$ \\
\hline
\end{tabular}

Y kuşağında yer alan katılımcıların aylık geliri incelendiğinde, \%70,2'sinin 3000TL ve altı gelire sahip olduğu görülmektedir. Bu durumun sebebi ise meslek dağılımında katılımcıların çoğunlukla öğrenci olmaları ve öğrencilikten hemen sonra gelen özel sektörde çalışmaları olabilir.

Tablo 12 Daha Önce Yurt Dışına Çıkma Durumuna Göre Dağılım

\begin{tabular}{|l|l|c|c|}
\hline \multicolumn{2}{|c|}{} & frekans & $\%$ \\
\hline \multirow{2}{*}{ Yurt Dışı } & Evet & 134 & 26,8 \\
\cline { 2 - 4 } & Hayır & 366 & 73,2 \\
\hline Toplam & 500 & $\% 100$ \\
\hline
\end{tabular}

Y kuşağında yer alan katılımcıların yurt dışında bulunma durumları incelendiğinde, çoğunluğu oluşturan \%73,2'sinin daha önce yurt dişına çıkmadığı görülmektedir. Bunun en büyük sebebinin Türkiye'den yurt dışına yapılan seyahat maliyetlerinin yüksek ve vize prosedürünün zahmetli olması olduğu söylenebilir. 


\subsection{Y KUŞAĞININ YABANCI ÜRÜN YARGISI VE SATIN ALMA NIYET ÖLÇEĞİNE İLIŞKİN BULGULAR}

Tablo 13 Yabancı Ürün Yargısı ve Satın Alma Niyet Ölçeğine İlişkin Soruların Dağılımı

\begin{tabular}{|c|c|c|c|c|c|c|c|c|c|c|c|}
\hline & 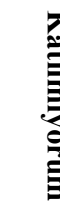 & $\stackrel{\overrightarrow{0}}{\stackrel{0}{0}}$ & & & & & & & 晃 & $\overrightarrow{\stackrel{0}{0}}$ & Ort \pm SS \\
\hline & $\mathbf{n}$ & $\%$ & $\mathbf{n}$ & $\%$ & $\mathrm{n}$ & $\%$ & n & $\%$ & n & $\%$ & \\
\hline $\begin{array}{l}\text { 1.Yabanc1 ürünler yerli } \\
\text { ürünlere göre teknolojik } \\
\text { olarak daha ileridir. }\end{array}$ & 66 & 13,2 & 59 & 11,8 & 58 & 11,6 & 177 & 35,4 & 140 & 28,0 & $3,53 \pm 1,36$ \\
\hline $\begin{array}{l}\text { 2. Yabancı ürünlerin tasarımı } \\
\text { yerli ürünlere göre daha } \\
\text { kullanışlıdır. }\end{array}$ & 33 & 6,6 & 77 & 15,4 & 107 & 21,4 & 161 & 32,2 & 122 & 24,4 & $3,52 \pm 1,20$ \\
\hline $\begin{array}{lll}\text { 3.Yabanc1 ürünler } & \text { yerli } \\
\text { ürünlere } & \text { göre } & \text { daha } \\
\text { dayanıklıdır. } & & \end{array}$ & 41 & 8,2 & 93 & 18,6 & 105 & 21,0 & 157 & 31,4 & 104 & 20,8 & $3,38 \pm 1,23$ \\
\hline $\begin{array}{lll}\text { 4.Yabanc1 } & \text { ürünler } & \text { pahalı } \\
\text { olsa bile } & \text { verilen } & \text { paraya } \\
\text { değerdir. } & & \\
& & \end{array}$ & 61 & 12,2 & 116 & 23,2 & 137 & 27,4 & 102 & 20,4 & 84 & 16,8 & $3,06 \pm 1,26$ \\
\hline $\begin{array}{l}\text { 5.Yabancı bir ürün satın } \\
\text { aldığımda kendimi suçlu } \\
\text { hissederim. }\end{array}$ & 120 & 24,0 & 157 & 31,4 & 108 & 21,6 & 75 & 15,0 & 40 & 8,0 & $2,52 \pm 1,23$ \\
\hline $\begin{array}{l}\text { 6. Yabancı ürüne sahip olma } \\
\text { fikrini sevmiyorum. }\end{array}$ & 90 & 18,0 & 145 & 29,0 & 108 & 21,6 & 102 & 20,4 & 55 & 11,0 & $2,77 \pm 1,27$ \\
\hline $\begin{array}{l}\text { 7.Biri yerli diğeri yabancı } \\
\text { iki ürün kalite bakımından } \\
\text { eşit olsa, yerli ürün için } \\
\text { daha fazla para } \\
\text { ödeyebilirim. }\end{array}$ & 47 & 9,4 & 99 & 19,8 & 96 & 19,2 & 130 & 26,0 & 128 & 25,6 & $3,39 \pm 1,31$ \\
\hline $\begin{array}{l}\text { 8.Asla yabancı ürün satın } \\
\text { almam. }\end{array}$ & 185 & 37,0 & 150 & 30,0 & 94 & 18,8 & 50 & 10,0 & 21 & 4,2 & $2,14 \pm 1,15$ \\
\hline $\begin{array}{l}\text { 9.Ürünün ait olduğu ülke, } \\
\text { kalitesi hakkında fikir verir. }\end{array}$ & 66 & 13,2 & 59 & 11,8 & 58 & 11,6 & 177 & 35,4 & 140 & 28,0 & $3,53 \pm 1,36$ \\
\hline $\begin{array}{l}\text { 10.Ürün satın alırken nerede } \\
\text { üretildiğini öğrenmek için } \\
\text { etiketine bakarım. }\end{array}$ & 33 & 6,6 & 77 & 15,4 & 107 & 21,4 & 161 & 32,2 & 122 & 24,4 & $3,52 \pm 1,20$ \\
\hline
\end{tabular}


Ölçekte yer alan ilk 8 soru çalışmayla benzer konularda yapılan yerli ve yabancı ürünlere karşı ürün yargı ve satın alma niyetini ölçmek amacı ile kullanılan önermelerden oluşmakta olup Klein ve Ettenson (1998) yılında yaptığı çalışmasından alınmıştır. Son iki önermeler ise menşei ülke etkisi çalışılan bir çok araştırmada yer alan katılımcıların bir ürünü almadan önce ürün ile ilgili bilgi edinmek için hangi ülkede üretildiğini öğrenmek amacı ile etiketine bakma sıklığını ölçen sorulardan oluşmaktadır.

Genel olarak tablo incelendiğinde, 1, 2, ve 3. önermeler sonucu, Afyonkarahisar ilinde yaşayan Y kuşağı katılımcılarının, yabancı ürünleri teknoloji, tasarım ve dayanıklılık bakımından yerli ürünlere göre daha ileride gördüğü sonucu ortaya çıkmaktadır. 4. önermede fiyat bakımından yabancı ürünlerin değerlendirilmesine yönelik "Yabancı ürünler pahalı olsa bile verilen paraya değerdir" ifadesine katılma durumu ağırlıklı olarak katılmadıklarını ortaya koymaktadır. 5, 6, ve 8. önermelerde sırsıyla yer alan "Yabancı bir ürün satın aldığımda kendimi suçlu hissederim", "Yabancı ürüne sahip olma fikrini sevmiyorum”, “Asla yabancı ürün satın almam” ifadelerine sirasıyla \%24,0 - \%29,0 - \%37,0 oranları ile katılmadıklarını belirterek genel olarak yabancı ürünlere karşı ön yargılı olmadıkları ve satın alma niyetlerinin olabileceği şeklinde değerlendirilmektedir. 7. önermedeki "Biri yerli diğeri yabanc1 iki ürün kalite bakımından eşit olsa, yerli ürün için daha fazla para ödeyebilirim" ifadesine \%26,0 katılıyorum ve \%25,6 kesinlikle katılıyorum oranları ile kendi ülke ürünlerinin kaliteli olduğu sürece bir ürün için fazla para ödemeyi göze aldıkları sonucu ortaya çıkmaktadır. Ürünün üretildiği yerin etkisini ölçmek amacı ile hazırlanmış 9. ve 10. önermelerde sırası ile yer alan "Ürünün ait olduğu ülke, kalitesi hakkında fikir verir", “Ürün satın alırken nerede üretildiğini öğrenmek için etiketine bakarım” ifadelerine ise sırasıyla, \%35,4 - \%32,2 oranları ile katılarak genel olarak ürün satın alırken etiketlerine bakıp ürün hakkında fikir sahibi oldukları yönünde yorum yapılabilir. 
Araştırmada kullanılan ölçeklerin güvenilirliğini ölçmek amacı ile Cronbach Alfa katsayıları bulunmuş olup bölüm bölüm incelenmiş anket soru dağılımların altında gösterilmiştir. Güvenilirlik, bir ölçeğin veya testin ölçmek istediği şeyi tutarlı ve istikrarlı bir şekilde ölçme derecesidir. Güvenilir bir ölçek veya test benzeri durumlarda tekrar uygulandığı zaman benzeri sonuçları vermektedir. Test veya ölçeğin güvenirliğini ölçmede iç tutarlılık yakşalımı kullanılmakla birlite bu yaklaşımı ölçek için Cronbah Alfa katsayısı kullanılmaktadır (Altunışık vd., 2010:122-124).

Alfa katsayısının değerlendirilmesi aşağıdaki ölçüte göre yapılır:

$0.0<0.40$ ise ölçek güvenilir değildir.

$0.40<0.60$ ise ölçek düşük güvenirliktedir

$0.60<0.80$ ise oldukça güvenilirdir.

$0.80<1.00$ ise ölçek yüksek derecede güvenilir bir ölçektir (Kalayacı, 2009:405)

Tablo 14 Ölçeğin Madde Sayısı ve Cronbach Alpha İç Tutarlılık Katsayısı

\begin{tabular}{|l|c|c|}
\hline & Soru sayısı & Cronbach's Alfa \\
\hline Yabancı Ürün Yargısı ve Satın Alma Niyet Ölçeği & 8 & 0,765 \\
\hline
\end{tabular}

Yabancı ürün yargısı ve satın alma niyet ölçeği iç tutarlılığının incelenmesi sonrasında Cronbach Alfa değeri $r=0,765$ güvenilirlik değeri elde edilmiştir. Buna göre ölçeğin oldukça güvenilir olduğu gözlemlenmiştir. 


\subsection{Y KUŞAĞININ SINIFLANDIRILMIȘ ÜRÜN GRUPLARINA İLISTKIN}

BULGULAR

Tablo 15 Sınıflandırılmış Ürün Gruplarına İlişkin Soruların Dağılımı

\begin{tabular}{|c|c|c|c|c|c|c|c|c|c|c|c|}
\hline & 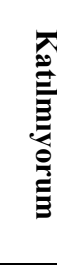 & 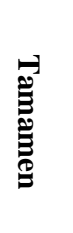 & \multicolumn{2}{|c|}{ 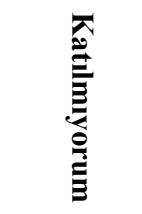 } & \multicolumn{2}{|c|}{ 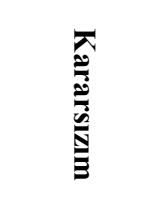 } & \multicolumn{2}{|c|}{ 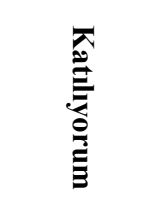 } & \multicolumn{2}{|c|}{ 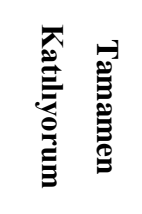 } & \multirow[t]{2}{*}{$\operatorname{Ort} \pm \mathrm{SS}$} \\
\hline & $\mathbf{n}$ & $\%$ & $\mathbf{n}$ & $\%$ & $\mathbf{n}$ & $\%$ & $\mathrm{n}$ & $\%$ & $\mathbf{n}$ & $\%$ & \\
\hline $\begin{array}{l}\text { 1.Market ürünlerinde yerli } \\
\text { markalar yabancı markalardan } \\
\text { daha iyidir. }\end{array}$ & 54 & 10,8 & 90 & 18,0 & 128 & 25,6 & 133 & 26,6 & 95 & 19,0 & $3,25 \pm 1,26$ \\
\hline $\begin{array}{l}\text { 2.Mağaza ürünlerinde yerli } \\
\text { markalar yabancı markalardan } \\
\text { daha iyidir. }\end{array}$ & 42 & 8,4 & 135 & 27,0 & 161 & 32,2 & 109 & 21,8 & 53 & 10,6 & $2,99 \pm 1,12$ \\
\hline $\begin{array}{l}\text { 3.Pahalı ve lüks ürünlerde yerli } \\
\text { markalar yabancı markalardan } \\
\text { daha iyidir. }\end{array}$ & 76 & 15,2 & 160 & 32,0 & 138 & 27,6 & 80 & 16,0 & 46 & 9,2 & $2,72 \pm 1,17$ \\
\hline $\begin{array}{l}\text { 4.Market alışverişinde aynı } \\
\text { kaliteye sahip iki markadan yerli } \\
\text { olanı tercih ederim. }\end{array}$ & 22 & 4,4 & 41 & 8,2 & 72 & 14,4 & 171 & 34,2 & 194 & 38,8 & $3,95 \pm 1,12$ \\
\hline $\begin{array}{l}\text { 5.Mağaza alışverişinde aynı } \\
\text { kaliteye sahip iki markadan yerli } \\
\text { olanı tercih ederim. }\end{array}$ & 25 & 5,0 & 50 & 10,0 & 94 & 18,8 & 166 & 33,2 & 165 & 33,0 & $3,79 \pm 1,15$ \\
\hline $\begin{array}{l}\text { 6.Pahalı ve lüks ürün } \\
\text { alışverişinde aynı kaliteye sahip } \\
\text { iki markadan yerli olanı tercih } \\
\text { ederim. }\end{array}$ & 46 & 9,2 & 63 & 12,6 & 79 & 15,8 & 154 & 30,8 & 158 & 31,6 & $3,63 \pm 1,29$ \\
\hline $\begin{array}{l}\text { 7.Market alışverişinde yerli ürün } \\
\text { gittiğim yerde yoksa o ürünü } \\
\text { başka yerde ararım. }\end{array}$ & 47 & 9,4 & 146 & 29,2 & 125 & 25,0 & 121 & 24,2 & 61 & 12,2 & $3,01 \pm 1,18$ \\
\hline $\begin{array}{l}\text { 8.Mağaza alışverişinde yerli ürün } \\
\text { gittiğim yerde yoksa o ürünü } \\
\text { başka yerde ararım. }\end{array}$ & 52 & 10,4 & 167 & 33,4 & 136 & 27,2 & 95 & 19,0 & 50 & 10,0 & $2,85 \pm 1,15$ \\
\hline $\begin{array}{l}\text { 9.Pahalı ve lüks ürün } \\
\text { alışverişinde yerli ürün gittiğim } \\
\text { yerde yoksa o ürünü başka yerde } \\
\text { ararım. }\end{array}$ & 60 & 12,0 & 170 & 34,0 & 127 & 25,4 & 94 & 18,8 & 49 & 9,8 & $2,8 \pm 1,17$ \\
\hline
\end{tabular}


Tablo 15: Sınıflandırılmış Ürün Gruplarına İlişsin Soruların Dağılımı Tablosunun Devamı

\begin{tabular}{|c|c|c|c|c|c|c|c|c|c|c|c|}
\hline $\begin{array}{l}\text { 10.Market alışverişinde yabancı } \\
\text { bir markada indirim varsa yerli } \\
\text { marka yerine onu tercih ederim. }\end{array}$ & 46 & 9,2 & 97 & 19,4 & 120 & 24,0 & 168 & 33,6 & 69 & 13,8 & $3,23 \pm 1,18$ \\
\hline $\begin{array}{l}\text { 11.Mağaza alışverişinde yabancı } \\
\text { bir markada indirim varsa yerli } \\
\text { marya yerine onu tercih ederim. }\end{array}$ & 26 & 5,2 & 75 & 15,0 & 130 & 26,0 & 189 & 37,8 & 80 & 16,0 & $3,44 \pm 1,09$ \\
\hline $\begin{array}{l}\text { 12.Pahalı ve lüks ürün } \\
\text { alışverişinde yabancı bir markada } \\
\text { indirim varsa yerli marka yerine } \\
\text { onu tercih ederim. }\end{array}$ & 27 & 5,4 & 74 & 14,8 & 117 & 23,4 & 189 & 37,8 & 93 & 18,6 & $3,49 \pm 1,12$ \\
\hline $\begin{array}{l}\text { 13.Market ürünlerinde yabancı } \\
\text { markalı biri ürün satın almak } \\
\text { benim için statü ve itibar } \\
\text { simgesidir. }\end{array}$ & 170 & 34,0 & 149 & 29,8 & 94 & 18,8 & 56 & 11,2 & 31 & 6,2 & $2,26 \pm 1,21$ \\
\hline $\begin{array}{l}\text { 14.Mağaza ürünlerinde yabancı } \\
\text { markalı ürün satın almak benim } \\
\text { için statü ve itibar simgesidir. }\end{array}$ & 153 & 30,6 & 134 & 26,8 & 87 & 17,4 & 77 & 15,4 & 49 & 9,8 & $2,47 \pm 1,33$ \\
\hline $\begin{array}{l}\text { 15.Pahalı ve lüks ürünlerde } \\
\text { yabancı markalı ürün satın almak } \\
\text { benim için statü ve itibar } \\
\text { simgesidir. }\end{array}$ & 145 & 29,0 & 130 & 26,0 & 79 & 15,8 & 85 & 17,0 & 61 & 12,2 & $2,57 \pm 1,38$ \\
\hline
\end{tabular}

15 önermeden oluşan ölçekte yer alan market ürünleri (gıda, temizlik, kozmetik, kişisel bakım) daha çok günlük hayatta kullanılan kolay erişim sağlanan, mağaza ürünleri (giyim, ayakkabı, aksesuar, çanta, beyaz eşya, ev elektroniği, mobilya küçük ev aletleri, oyun ve eğlence setleri) daha çok satın alma sırasında üzerinde düşündüren beğenmeli ürünler, pahalı ve lüks ürünler (otomobil, ev, pahalı elektronik ürünler, pahalı mobilyalar, sanatsal ürünler, mücevher, koleksiyon ürünleri) daha çok satın almadan önce üzerinde uzun süre düşünülen, kolayca erişim sağlanamayan lüks ürünlerden oluşturulmuş olup katılımcıların yerli ve yabancı ürünlere karşı tutum ve davranışlarını kategorize edilen ürün grupları için değerlendirilmesi istenilen (Arı, 2007, Özmen, 2004) çalışmalarından uyarlanmış sorulardan oluşmaktadır. Tablo $15^{\prime}$ 'de sınıflandırılmış ürün gruplarına ilişkin soru dağılımı ve katılımcıların verdikleri cevapların genel dağılımı gösterilmiş olup daha ayrıntılı incelemek adına market ürünleri, mağaza ürünleri ve pahalı-lüks ürünler 
olarak ayrı ayrı değerlendirilerek katılımcıların verdikleri cevap dağılımı tablo 16 ' da gösterilmiştir.

Tablo 16 Ölçeğin Madde Sayısı ve Cronbach Alpha İç Tutarlılık Katsayısı

\begin{tabular}{|l|c|c|}
\hline & Soru sayısı & Cronbach's Alfa \\
\hline Davranışsal Marka Sadakati Ölçeği & 15 & 0,764 \\
\hline
\end{tabular}

Davranışsal marka sadakati ölçeği iç tutarlılığının incelenmesi sonrasında Cronboch Alfa $r=0,764$ güvenilirlik değeri elde edilmiştir. Buna göre ölçeğimizin oldukça güvenilir olduğu gözlemlenmiştir.

Tablo 17 Market Ürünleri Olarak Gruplandırılmış Soru Dağılımı

\begin{tabular}{|c|c|c|c|c|c|c|c|c|c|c|c|}
\hline & \multicolumn{2}{|c|}{ 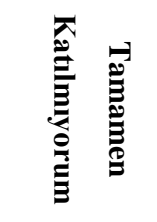 } & \multicolumn{2}{|c|}{ 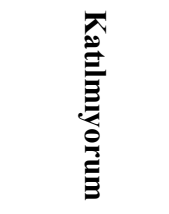 } & \multicolumn{2}{|c|}{ 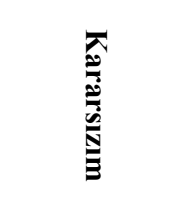 } & \multicolumn{2}{|c|}{ 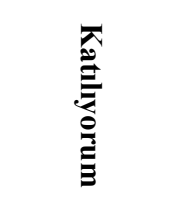 } & \multicolumn{2}{|c|}{ 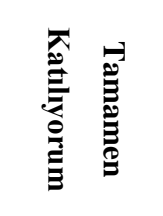 } & \multirow[t]{2}{*}{ Ort \pm SS } \\
\hline & n & $\%$ & n & $\%$ & $\mathbf{n}$ & $\%$ & $\mathrm{n}$ & $\%$ & n & $\%$ & \\
\hline $\begin{array}{l}\text { 1.Market ürünlerinde } \\
\text { yerli markalar yabancı } \\
\text { markalardan daha iyidir. }\end{array}$ & 54 & 10,8 & 90 & 18,0 & 128 & 25,6 & 133 & 26,6 & 95 & 19,0 & $3,25 \pm 1,26$ \\
\hline $\begin{array}{l}\text { 4.Market alışverişinde } \\
\text { aynı kaliteye sahip iki } \\
\text { markadan yerli olanı } \\
\text { tercih ederim. }\end{array}$ & 22 & 4,4 & 41 & 8,2 & 72 & 14,4 & 171 & 34,2 & 194 & 38,8 & $3,95 \pm 1,12$ \\
\hline $\begin{array}{l}\text { 7.Market alısverişinde } \\
\text { yerli ürün gittiğim yerde } \\
\text { yoksa o ürünü başka } \\
\text { yerde ararım. }\end{array}$ & 47 & 9,4 & 146 & 29,2 & 125 & 25,0 & 121 & 24,2 & 61 & 12,2 & $3,01 \pm 1,18$ \\
\hline $\begin{array}{l}\text { 10.Market alışverişinde } \\
\text { yabancı bir markada } \\
\text { indirim varsa yerli marka } \\
\text { yerine onu tercih ederim. }\end{array}$ & 46 & 9,2 & 97 & 19,4 & 120 & 24,0 & 168 & 33,6 & 69 & 13,8 & $3,23 \pm 1,18$ \\
\hline $\begin{array}{l}\text { 13.Market ürünlerinde } \\
\text { yabancı markalı biri ürün } \\
\text { satın almak benim için } \\
\text { statü ve itibar simgesidir. }\end{array}$ & 170 & 34,0 & 149 & 29,8 & 94 & 18,8 & 56 & 11,2 & 31 & 6,2 & $2,26 \pm 1,21$ \\
\hline
\end{tabular}

Tablo incelendiğinde market ürünleri olarak ele alınan; gıda, temizlik, kozmetik ve kişisel bakım ürünleri gibi daha çok gündelik hayatta kullanılan kolay 
erişilen ürünleri kapsamaktadır. Afyonkarahisar ilinde yaşayan Y kuşağı üyelerinin önermelere verdikleri cevaplar incelendiğinde, 1 . önermede \%26,6 katılma oranında market ürünlerinde yerli ürünlerin yabancı ürünlerden daha iyi olduğu görüşünde oldukları sonucu çıkmaktadır. Gıda ürünlerini de kapsayan market ürün gruplarında yerli ürün tercih edilmesinin sebebi olarak müslüman ülkede yaşamamız ve dini inançlara bağlı olarak yediğimiz şeylere dikkat etmemizin gerekli olduğu söylenebilir. 4. önermede $\% 38,8$ oranında kesinlikle katıldıkları aynı kaliteye sahip iki ürün arasında yerli ürünü tercih ettikleri sonucu çıkmaktadır. 7. önermede yer alan "Market alışverişinde yerli ürün gittiğim yerde yoksa o ürünü başka yerde ararım" ifadesine ise \%29,2 oranında katılmadıklarını yani market ürünlerin kesinlikle yerli ürün olsun diye her hangi bir çaba sarf etmedikleri şeklinde yorum yapılabilir. 10. önermede yer alan "Market alışverişinde yabancı bir markada indirim varsa yerli marka yerine onu tercih ederim" ifadesine \%33,6 oranında katıldıkları görülerek market ürünü satın alırken fiyat faktörüne önem verdikleri, onlar için yerli veya yabancı ürünlerde önemli olan ucuz olması sonucuna varılabilir. 13. önermede yer alan "Market ürünlerinde yabancı markalı biri ürün satın almak benim için statü ve itibar simgesidir" ifadesine ise $\% 34,0$ oranında kesinlikle katılmadıklarını belirterek market ürünü satın almanın onlar için herhangi bir statü sembolü olmadığı sonucu ortaya çıkmaktadır. 
Tablo 18 Mağaza Ürünleri Olarak Gruplandırılmış Soruların Dağılımı

\begin{tabular}{|c|c|c|c|c|c|c|c|c|c|c|c|}
\hline & \multicolumn{2}{|c|}{ 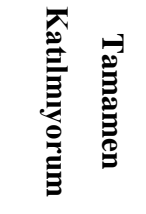 } & \multicolumn{2}{|c|}{ 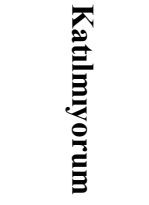 } & \multicolumn{2}{|c|}{ 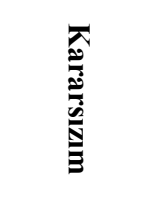 } & \multicolumn{2}{|c|}{ 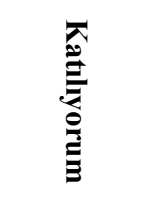 } & \multicolumn{2}{|c|}{ 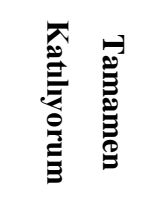 } & \multirow[t]{2}{*}{ Ort \pm SS } \\
\hline & $\mathbf{n}$ & $\%$ & $\mathbf{n}$ & $\%$ & $\mathbf{n}$ & $\%$ & n & $\%$ & $\mathbf{n}$ & $\%$ & \\
\hline $\begin{array}{l}\text { 2.Mağaza ürünlerinde yerli } \\
\text { markalar yabancı } \\
\text { markalardan daha iyidir. }\end{array}$ & 42 & 8,4 & 135 & 27,0 & 161 & 32,2 & 109 & 21,8 & 53 & 10,6 & $2,99 \pm 1,12$ \\
\hline $\begin{array}{l}\text { 5.Mağaza alışverişinde aynı } \\
\text { kaliteye sahip iki markadan } \\
\text { yerli olanı tercih ederim. }\end{array}$ & 25 & 5,0 & 50 & 10,0 & 94 & 18,8 & 166 & 33,2 & 165 & 33,0 & $3,79 \pm 1,15$ \\
\hline $\begin{array}{l}\text { 8.Mağaza alışverişinde yerli } \\
\text { ürün gittiğim yerde yoksa o } \\
\text { ürünü başka yerde ararım. }\end{array}$ & 52 & 10,4 & 167 & 33,4 & 136 & 27,2 & 95 & 19,0 & 50 & 10,0 & $2,85 \pm 1,15$ \\
\hline $\begin{array}{l}\text { 11.Mağaza alışverişinde } \\
\text { yabancı bir markada } \\
\text { indirim varsa yerli marya } \\
\text { yerine onu tercih ederim. }\end{array}$ & 26 & 5,2 & 75 & 15,0 & 130 & 26,0 & 189 & 37,8 & 80 & 16,0 & $3,44 \pm 1,09$ \\
\hline $\begin{array}{l}\text { 14.Mağaza ürünlerinde } \\
\text { yabancı markalı ürün satın } \\
\text { almak benim için statü ve } \\
\text { itibar simgesidir. }\end{array}$ & 153 & 30,6 & 134 & 26,8 & 87 & 17,4 & 77 & 15,4 & 49 & 9,8 & $2,47 \pm 1,33$ \\
\hline
\end{tabular}

Tablo incelendiğinde, mağaza ürünleri olarak ele alınan; giyim ayakkabı, aksesuar, çanta, beyaz eşya, ev elektroniği, küçük ev aletleri, oyun ve eğlence setleri gibi daha çok satın alma sırasında üzerinde düşünülen beğenmeli ürünlerden oluşmaktadır. Afyonkarahisar ilinde yaşayan Y kuşağı katılımcıları, 2. önermede yer alan "Mağaza ürünlerinde yerli markalar yabancı markalardan daha iyidir" ifadesine ağırlık olarak katılmadıkları görülmekte olup mağaza ürünleri değerlendirmesinde yerli ürünleri çok iyi bulmadıkları şeklinde yorum yapılabilir. 5. önermede yer alan "Mağaza alışverişinde aynı kaliteye sahip iki markadan yerli olanı tercih ederim" ifadesine \%33,0 oranında kesinlikle katıldıklarını belirterek her iki ürün kalite olarak aynı ise yerli ürünü tercih etmekte oldukları görümektedir. 8. önermede yer alan "Mağaza alışverişinde yerli ürün gittiğim yerde yoksa o ürünü başka yerde ararım" 
ifadesine \%33,4 oranında katılmadıklarını belirterek satın alacakları bir mağaza ürünü için yerli ürün olsun diye her hangi bir çaba sarf etmedikleri şeklinde yorum yapılabilir. 11. önermede yer alan "Mağaza alışverişinde yabancı bir markada indirim varsa yerli marya yerine onu tercih ederim" ifadesine \%37,8 oranında katıldıklarını belirterek mağaza ürünü satın alırken fiyat faktörüne önem verdikleri, onlar için yerli veya yabancı ürünlerde önemli olan ucuz olması sonucuna varılabilir. 14. önermede yer alan "Mağaza ürünlerinde yabancı markalı ürün satın almak benim için statü ve itibar simgesidir" ifadesine \%30,6 oranında kesinlikle katılmadıklarını belirterek mağaza ürünleri satın almanın onlar için bir statü sembolü olmadığı sonucuna ulaşılmaktadır.

Tablo 19 Pahalı ve Lüks Ürün Olarak Gruplandırılmış Soruların Dağılımı

\begin{tabular}{|c|c|c|c|c|c|c|c|c|c|c|c|}
\hline & \multicolumn{2}{|c|}{ 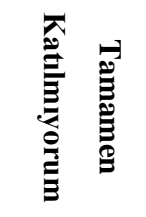 } & \multicolumn{2}{|c|}{ 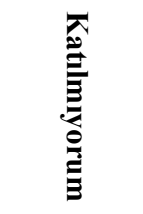 } & \multicolumn{2}{|c|}{ 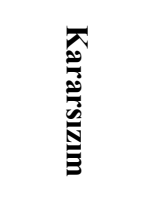 } & \multicolumn{2}{|c|}{ 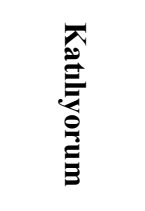 } & \multicolumn{2}{|c|}{ 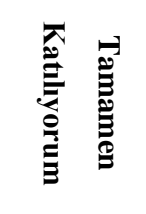 } & \multirow[t]{2}{*}{ Ort \pm SS } \\
\hline & n & $\%$ & $\mathbf{n}$ & $\%$ & n & $\%$ & $\mathbf{n}$ & $\%$ & $\mathbf{n}$ & $\%$ & \\
\hline $\begin{array}{l}\text { 3.Pahalı ve lüks ürünlerde yerli } \\
\text { markalar yabancı markalardan } \\
\text { daha iyidir. }\end{array}$ & 76 & 15,2 & 160 & 32,0 & 138 & 27,6 & 80 & 16,0 & 46 & 9,2 & $2,72 \pm 1,17$ \\
\hline $\begin{array}{l}\text { 6.Pahalı ve lüks ürün } \\
\text { alışverişinde aynı kaliteye sahip } \\
\text { iki markadan yerli olanı tercih } \\
\text { ederi. }\end{array}$ & 46 & 9,2 & 63 & 12,6 & 79 & 15,8 & 154 & 30,8 & 158 & 31,6 & $3,63 \pm 1,29$ \\
\hline $\begin{array}{l}\text { 9.Pahalı ve lüks ürün } \\
\text { alışverişinde yerli ürün gittiğim } \\
\text { yerde yoksa o ürünü başka } \\
\text { yerde ararım. }\end{array}$ & 60 & 12,0 & 170 & 34,0 & 127 & 25,4 & 94 & 18,8 & 49 & 9,8 & $2,8 \pm 1,17$ \\
\hline $\begin{array}{l}\text { 12.Pahalı ve lüks ürün } \\
\text { alışverişinde yabancı } \\
\text { markada indirim varsa yerli } \\
\text { marka yerine onu tercih ederim. }\end{array}$ & 27 & 5,4 & 74 & 14,8 & 117 & 23,4 & 189 & 37,8 & 93 & 18,6 & $3,49 \pm 1,12$ \\
\hline $\begin{array}{l}\text { 15.Pahalı ve lüks ürünlerde } \\
\text { yabancı markalı ürün satın } \\
\text { almak benim için statü ve itibar } \\
\text { simgesidir. }\end{array}$ & 145 & 29,0 & 130 & 26,0 & 79 & 15,8 & 85 & 17,0 & 61 & 12,2 & $2,57 \pm 1,38$ \\
\hline
\end{tabular}


Tablo incelendiğinde, pahalı ve lüks ürünler olarak ele alınan; otomobil, ev, pahalı elektronik ürünler, pahalı mobilyalar, sanatsal ürünler, mücevher, koleksiyon ürünleri gibi satın almadan önce üzerinde uzun süre düşünülen, kolayca erişilemeyen lüks ürünlerden oluşmaktadır. Afyonkarahisar ilinde yaşayan Y kuşağı üyeleri, 3. önermede yer alan "Pahalı ve lüks ürünlerde yerli markalar yabancı markalardan daha iyidir" ifadesine $\% 32,0$ oranında katılmadıklarını belirterek pahalı ve lüks ürünleri değerlendirmesinde yerli ürünleri çok iyi bulmadıkları şeklinde yorum yapılabilir. 6. önermede yer alan "pahalı ve lüks ürün alışverişinde aynı kaliteye sahip iki markadan yerli olanı tercih ederim" ifadesine \%31,6 oranında kesinlikle katıldıkları belirterek her iki ürün kalite olarak aynı ise yerli ürünü tercih etmekte oldukları gözlemlenmektedir. 9. önermede yer alan "pahalı ve lüks ürün alışverişinde yerli ürün gittiğim yerde yoksa o ürünü başka yerde ararım" ifadesine \%34,0 oranında katılmadıklarını belirterek satın alacakları pahalı ve lük ürün için yerli ürün olsun diye her hangi bir çaba sarf etmedikleri şeklinde yorum yapılabilir. 12. önermede yer alan "Pahalı ve lüks ürün alışverişinde yabancı bir markada indirim varsa yerli marya yerine onu tercih ederim" ifadesine \% 37,8oranında katıldıklarını belirterek pahalı ve lüks ürün satın alırken fiyat faktörüne önem verdikleri, onlar için yerli veya yabancı ürünlerde önemli olan ucuz olması sonucuna varılabilir. 15. önermede yer alan "Pahalı ve lüks ürünlerde yabancı markalı ürün satın almak benim için statü ve itibar simgesidir" ifadesine 29,0 oranında kesinlikle katılmadıklarını belirterek pahalı ve lüks ürün satın almanın onlar için bir statü sembolü olmadığı sonucuna ulaşılmaktadır. 


\subsection{Y KUŞAĞININ ETNOSENTRİK EĞİLIMLERİNE İLIŞKİN BULGULAR}

Tablo 20 Etnosentrik CESTCALE Ölçeğine İlişkin Soruların Dağılımı

\begin{tabular}{|c|c|c|c|c|c|c|c|c|c|c|c|}
\hline & \multicolumn{2}{|c|}{ 苞: } & \multicolumn{2}{|c|}{ 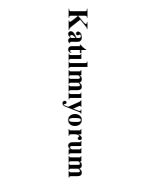 } & \multicolumn{2}{|c|}{ 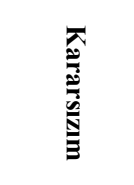 } & \multicolumn{2}{|c|}{ 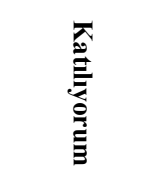 } & \multicolumn{2}{|c|}{ 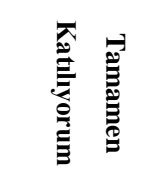 } & \multirow[t]{2}{*}{$\operatorname{Ort} \pm$ SS } \\
\hline & $\mathbf{n}$ & $\%$ & $\mathbf{n}$ & $\%$ & $\mathbf{n}$ & $\%$ & $\mathbf{n}$ & $\%$ & $\mathbf{n}$ & $\%$ & \\
\hline $\begin{array}{l}\text { 1.Yabancı ürünler yerine her } \\
\text { zaman yerli ürünler satın } \\
\text { alınmalıdır. }\end{array}$ & 54 & 10,8 & 90 & 18,0 & 128 & 25,6 & 133 & 26,6 & 95 & 19,0 & $3,2 \pm 1,27$ \\
\hline $\begin{array}{l}\text { 2.Sadece, } \\
\text { üretilmeyen ürkiye'de } \\
\text { edilmelidir. }\end{array}$ & 42 & 8,4 & 135 & 27,0 & 161 & 32,2 & 109 & 21,8 & 53 & 10,6 & $3,49 \pm 1,28$ \\
\hline $\begin{array}{l}\text { 3.Yerli ürünler satın alınarak } \\
\text { Türkiye'nin } \\
\text { artırılmalıdır. }\end{array}$ & 76 & 15,2 & 160 & 32,0 & 138 & 27,6 & 80 & 16,0 & 46 & 9,2 & $3,93 \pm 1,06$ \\
\hline $\begin{array}{l}\text { 4.Türkiye'de üretilen ürünler } \\
\text { her zaman benim için } \\
\text { önceliklidir. }\end{array}$ & 22 & 4,4 & 41 & 8,2 & 72 & 14,4 & 171 & 34,2 & 194 & 38,8 & $3,54 \pm 1,17$ \\
\hline $\begin{array}{l}\text { 5.Yabancı ürünleri satın } \\
\text { almak milli bir davranış } \\
\text { değildir. }\end{array}$ & 25 & 5,0 & 50 & 10,0 & 94 & 18,8 & 166 & 33,2 & 165 & 33,0 & $2,90 \pm 1,29$ \\
\hline $\begin{array}{l}\text { 6.Yabancı ürünleri satın } \\
\text { almak doğru değildir çünkü } \\
\text { vatandaşların işsiz kalmasına } \\
\text { neden olur. }\end{array}$ & 46 & 9,2 & 63 & 12,6 & 79 & 15,8 & 154 & 30,8 & 158 & 31,6 & $2,83 \pm 1,22$ \\
\hline $\begin{array}{l}\text { 7.Gerçek bir Türkiye } \\
\text { vatandaşı her zaman yerli } \\
\text { ürünleri satın almalıdır. }\end{array}$ & 47 & 9,4 & 146 & 29,2 & 125 & 25,0 & 121 & 24,2 & 61 & 12,2 & $2,91 \pm 1,25$ \\
\hline $\begin{array}{lrr}\text { 8.Diğer ülkelerin } & \text { bize mal } \\
\text { satarak zengin } & \text { olmasına } \\
\text { müsaade etmek yerine } \\
\text { Türkiye'de üretilen ürünleri } \\
\text { satın almalıyız. }\end{array}$ & 52 & 10,4 & 167 & 33,4 & 136 & 27,2 & 95 & 19,0 & 50 & 10,0 & $3,37 \pm 1,22$ \\
\hline $\begin{array}{l}\text { 9.Her zaman en doğrusu yerli } \\
\text { ürünleri satın almaktır. }\end{array}$ & 60 & 12,0 & 170 & 34,0 & 127 & 25,4 & 94 & 18,8 & 49 & 9,8 & $3,24 \pm 1,21$ \\
\hline
\end{tabular}


Tablo 20: Etnosentrik CESTCALE Ölçeğine İlişkin Soruların Dağılımı Tablosunun Devamı

\begin{tabular}{|c|c|c|c|c|c|c|c|c|c|c|c|}
\hline $\begin{array}{l}\text { 10.Gerekli olmadığı sürece } \\
\text { diğer ülkelerle ürün ticareti } \\
\text { veya satın alımı çok az } \\
\text { olmalıdır. }\end{array}$ & 46 & 9,2 & 97 & 19,4 & 120 & 24,0 & 168 & 33,6 & 69 & 13,8 & $3,44 \pm 1,19$ \\
\hline $\begin{array}{l}\text { 11.Türkiye'nin ticaretine } \\
\text { zarar verip, işsizliğe yol açtığı } \\
\text { için vatandaşlar yabancı ürün } \\
\text { satın almamalıdır. }\end{array}$ & 26 & 5,2 & 75 & 15,0 & 130 & 26,0 & 189 & 37,8 & 80 & 16,0 & $3,10 \pm 1,19$ \\
\hline $\begin{array}{l}\text { 12.Yabancı ürünlerin } \\
\text { ithalatına } \\
\text { getirilmelidir. }\end{array}$ & 27 & 5,4 & 74 & 14,8 & 117 & 23,4 & 189 & 37,8 & 93 & 18,6 & $3,14 \pm 1,19$ \\
\hline $\begin{array}{l}\text { 13.Uzun vadede bana daha } \\
\text { maliyetli olsa da yerli ürünleri } \\
\text { satın almayı tercih ederim. }\end{array}$ & 170 & 34,0 & 149 & 29,8 & 94 & 18,8 & 56 & 11,2 & 31 & 6,2 & $3,01 \pm 1,20$ \\
\hline $\begin{array}{lr}\text { 14.Yabancıların } & \text { ürünlerini } \\
\text { bizim } & \text { pazarımızda } \\
\text { satılmalarına } & \text { izin } \\
\text { verilmemelidir. } & \end{array}$ & 153 & 30,6 & 134 & 26,8 & 87 & 17,4 & 77 & 15,4 & 49 & 9,8 & $2,68 \pm 1,18$ \\
\hline $\begin{array}{l}\text { 15.Yabanc1 ürünlerin } \\
\text { Türkiye'ye girişlerini } \\
\text { azaltmak için, yüksek oranda } \\
\text { vergilendirilmelidir. }\end{array}$ & 145 & 29,0 & 130 & 26,0 & 79 & 15,8 & 85 & 17,0 & 61 & 12,2 & $2,88 \pm 1,28$ \\
\hline
\end{tabular}

Tablo incelendiğinde katılımcıların verdikleri cevaplarda göze çarpan değerler arasında \%38,8 oranında kesinlikle katıldıkları 4. önermede yer alan “Türkiye'de üretilen ürünler her zaman benim için önceliklidir" ifadesi yer almaktadır ve katılımcıların satın alma davranışı sergilerken ilk olarak kendi ülkelerinde üretilen ürünleri değerlendirdikleri görülmektedir. Daha sonra \%37,8 oranında katıldıkları 11. önermede yer alan “Türkiye'nin ticaretine zarar verip, işsizliğe yol açtığı için vatandaşlar yabancı ürün satın almamalıdır" ifadesi yer almaktadır. Genellikle yaş olarak genç kesimi hedef alan çalışmada, Türkiye'de işsizlik seviyesi yüksek olduğundan katılımcılar da işsizliğe neden olabileceği düşüncesini çağrıştırdığı için bu konuda hassas oldukları sonucuna varılabilir. 13. önermede yer alan "Uzun vadede bana daha maliyetli olsa da yerli ürünleri satın almayı tercih ederim" ifadesine ise \%34,0 oranında kesinlikle katılmadıklarını 
belirten katılımcıların, her ne kadar öncelikle Türk ürünleri tercih etme eğilimine sahip olsalar da fiyat faktörüne de önem verdikleri görülmektedir. 14. ve 15 . önermelerde sırasıyla yer alan "Yabancıların ürünlerini bizim pazarımızda satılmalarına izin verilmemelidir", "Yabancı ürünlerin Türkiye’ye girişlerini azaltmak için, yüksek oranda vergilendirilmelidir" ifadelerine \%30,6 - \%29,0 oranlarında kesinlikle katılmadıkları görülmektedir. Afyonkarahisar'da yaşayan Y kuşağ1 üyeleri, her ne kadar öncelik olarak kendi ülke ürünlerini satın alma eğiliminde olsalar da bu durumun kendi isteklerine göre herhangi bir yasaklama olmadan tercih etmek istedikleri görülmektedir.

Genel olarak verilen cevaplara baktığımızda Y kuşağı üyelerinin orta düzeyde etnosentrik eğilime sahip olduğu sonucu çıkmaktadır. Bu durumu bilimsel olarak da kanıtlamak için çoğu çalışmada kullanılan Cestcale ölçeğine verilmiş olan cevapları analiz ederken kolaylık sağlaması ve katılımcıların farklı etnosentrik düzeylerini belirlemek amacı ile katılımcıların skorlarına göre 3 grupta ele alınmıştır. Gruplar oluşturulurken beşli likert ölçeği, (1= Kesinlikle Katılmıyorum, 2= Katılmıyorum, $3=$ Karasızım, 4= Katılıyorum, 5= Kesinlikle Katılıyorum) temel alınarak, her iki uca (1 ve 5) eşit mesafede yer alan 3 değerinin her iki taraftan 0,5 birim alınarak oluşturulan aralık gruplamanın orta değeri olarak kabul edilmiş, bu aralığın altı düşük etnosentrik eğilime sahip, üzeri yüksek etnosentrik eğilime sahip şeklinde değerlendirilmiştir.. Buna göre "etnosentrik eğilimi düşük" olarak ifade edilen grubun bulunduğu birinci aralık (1-2,5 aralığı), 17x2,5=42,5 (43 olarak alınmış); "orta etnosentrik eğilimli"” olarak adlandırılan grubun bulunduğu ikinci aralık (2,5-3,5 aralığı), 17x3,5=59,5 (43-60 olarak alınmış); "etnosentrik eğilimi yüksek” olarak adlandırılan üçüncü grubun bulunduğu aralık ise 61 'den başlayıp (3,5-5 aralığı), 17x5=85 üst sınırı ile sınırlandırılmıştır (Arı, 2007; Akın vd., 2009). Aşağıdaki tabloda da gösterildiği gibi çalışmaya katılanların orta etnosentrik eğilime sahip olduğu gözlenmiştir. 
Tablo 21 Y Kuşağının Etnosentrik Eğilim Düzeylerine Göre Dağılımı

\begin{tabular}{|l|l|c|c|}
\hline \multicolumn{2}{|c|}{} & n & \% \\
\hline \multirow{3}{*}{ Etnosentrik Eŭilim } & Düşük & 69 & 13,8 \\
\cline { 2 - 4 } & Orta & 266 & 53,2 \\
\cline { 2 - 4 } & Yüksek & 165 & 33,0 \\
\hline
\end{tabular}

Araştırmaya katılan $\mathrm{Y}$ Kuşağı üyelerinin etnosentrik eğilimleri incelendiğinde, 13,8'inin düşük eğilim sergilediği, \%53,2'sinin orta eğilim sergilediği, \%33,0’ünün ise yüksek eğilim sergilediği sonucuna varılmıştır.

Tablo 22 Ölçeğin Madde Sayısı ve Cronbach Alpha İç Tutarlılık Katsayısı

\begin{tabular}{|l|c|c|}
\hline & Soru sayısi & Cronbach's Alfa \\
\hline Etnosentrizm Cestcale Ölçeği & 17 & 0,926 \\
\hline
\end{tabular}

Etnosentrizm Cestcale ölçeği iç tutarlılığının incelenmesi sonrasında Cronboch Alfa değeri $r=0,926$ güvenilirlik değeri elde edilmiştir. Buna göre ölçeğimizin yüksek derecede güvenilir olduğu gözlemlenmiştir. 


\subsection{FAKTÖR ANALİİ}

Hipotezlerin testi yapılmadan önce araştırmada kullanılan anketin Afyonkarahisar ilinde yaşayan Y kuşağı katılımcıları tarafından kaç boyutta algılandığını belirlemek amacı ile faktör analizi yapılmıştır. Faktör analizi değişkenler arasındaki ilişkilelere dayanarak çok sayıdaki değişkeni daha az sayıya indirebilen çok değişkenli bir analiz tekniğidir. Bu analizin yapılmasının ön şartı, örneklemin yeterli olup olmadığını gösteren Kaiser-Meyer-Olkin (KMO) ve değişkenler arasında faktör analizi yapılabilecek güçte bir ilişki olup olmadığını gösteren Bartlett Küresellik testleridir. KMO testinin 0.60'dan büyük olması, Bartlett testinin ise $\mathrm{P}$ değeri 0,05 'ten küçük olması faktör analizinin yapılması için uygun olduğunu belirtmektedir (İslamoğlu, 2009:234). Araştırmada faktör analizinin yapılabilmesi için örneklem yeterliliğinin sağlanıp sağlanmadığını saptamak amacı ile Kaiser-Mayer-Olkin (KMO) ve Bartlett testi yapılmıştır. Ölçeğe ilişkim KMO değer tablosu ve faktör analizi sonuçları aşağıdaki tablolarda gösterilmiştir.

Tablo 23 KMO ve Barlett Test Sonucu

\begin{tabular}{|l|l|r|}
\hline \multicolumn{2}{|c|}{ KMO ve Bartlett's Testi } \\
\hline \multicolumn{2}{|c|}{ Kaiser-Meyer-Olkin Örneklem Yeterliliği Ölçüsü } &, 900 \\
\hline Bartlett's Küresellik Testi & Yaklaşık Ki-kare & 10634,687 \\
\cline { 2 - 3 } & Serbestlik Derecesi & 861 \\
\cline { 2 - 3 } & Anlamlılık &, 000 \\
\hline
\end{tabular}

KMO değeri 0,90 olup oldukça yüksek bulunmuş ve Barttlet küresellik testi sonucu $(\mathrm{p}<0,001)$ oldukça anlamlı olup verilerin faktör analizine uygun olduğu anlaşılmıştır. Alt boyutların birbiri içine girmediği, aynı alt boyutlara ilişkin ifadelerin tek bir boyutta toplanabileceği anlaşılmıştır. 
Tablo 24 Faktör Analiz Sonucu

\begin{tabular}{|c|c|c|c|c|c|c|c|c|c|c|c|}
\hline & F1 & F2 & F3 & F4 & F5 & F6 & F7 & F8 & F9 & F10 & F11 \\
\hline \multicolumn{12}{|l|}{ Yabancı ürün yargısı } \\
\hline $\begin{array}{l}\text { 1. Yabancı ürünler yerli ürünlere göre } \\
\text { teknolojik olarak daha ileridir. }\end{array}$ & ,761 & & & & & & & & & & \\
\hline $\begin{array}{l}\text { 2. Yabanc1 ürünlerin tasarımı yerli } \\
\text { ürünlere göre daha kullanışlıdır. }\end{array}$ & ,841 & & & & & & & & & & \\
\hline $\begin{array}{l}\text { 3. Yabancı ürünler yerli ürünlere göre } \\
\text { daha dayanıklıdır. }\end{array}$ &, 825 & & & & & & & & & & \\
\hline $\begin{array}{l}\text { 4. Yabancı ürünler pahalı olsa bile } \\
\text { verilen paraya değerdir. }\end{array}$ & ,688 & & & & & & & & & & \\
\hline \multicolumn{12}{|l|}{ Yabancı ürün satın alma niyeti } \\
\hline $\begin{array}{l}\text { 5. Yabancı bir ürün satın aldığımda } \\
\text { kendimi suçlu hissederim. }\end{array}$ & & ,712 & & & & & & & & & \\
\hline $\begin{array}{l}\text { 6.Yabancı ürüne sahip olma fikrini } \\
\text { sevmiyorum. }\end{array}$ & & ,766 & & & & & & & & & \\
\hline $\begin{array}{l}\text { 7. Biri yerli diğeri yabancı iki ürün } \\
\text { kalite bakımından eşit olsa, yerli ürün } \\
\text { için daha fazla para ödeyebilirim. }\end{array}$ & & 576 & & & & & & & & & \\
\hline 8. Asla yabancı ürün satın almam. & & ,454 & & & & & & & & & \\
\hline \multicolumn{12}{|l|}{ Menșe ülke etkisi } \\
\hline $\begin{array}{l}\text { 9. Ürünün ait olduğu ülke, kalitesi } \\
\text { hakkında fikir verir. }\end{array}$ & & & ,717 & & & & & & & & \\
\hline $\begin{array}{l}\text { 10. Ürün satın alırken nerede } \\
\text { üretildiğini ögrrenmek için etiketine } \\
\text { bakarım. }\end{array}$ & & & ,777 & & & & & & & & \\
\hline \multicolumn{12}{|c|}{ Sınıflandırılmıș ürün gruplarında yerli ürün önceliği } \\
\hline $\begin{array}{l}\text { 11. Market ürünlerinde yerli } \\
\text { markalar yabancı markalardan daha } \\
\text { iyidir. }\end{array}$ & & & & 577 & & & & & & & \\
\hline $\begin{array}{l}\text { 12. Mağaza ürünlerinde yerli } \\
\text { markalar yabancı markalardan daha } \\
\text { iyidir. }\end{array}$ & & & & ,731 & & & & & & & \\
\hline $\begin{array}{l}\text { 13. Pahalı ve lüks ürünlerde yerli } \\
\text { markalar yabancı markalardan daha } \\
\text { iyidir. }\end{array}$ & & & & 577 & & & & & & & \\
\hline \multicolumn{12}{|c|}{ Sınıflandırılmış ürün gruplarında kaliteye göre yerli ürün önceliği } \\
\hline $\begin{array}{l}\text { 14. Market alışverişinde aynı } \\
\text { kaliteye sahip iki markadan yerli } \\
\text { olanı tercih ederim. }\end{array}$ & & & & & ,776 & & & & & & \\
\hline $\begin{array}{l}\text { 15. Mağaza alışverişinde aynı } \\
\text { kaliteye sahip iki markadan yerli } \\
\text { olanı tercih ederim. }\end{array}$ & & & & & ,838 & & & & & & \\
\hline $\begin{array}{l}\text { 16. Pahalı ve lüks ürün alışverişinde } \\
\text { aynı kaliteye sahip iki markadan yerli } \\
\text { olanı tercih ederim. }\end{array}$ & & & & & ,768 & & & & & & \\
\hline \multicolumn{12}{|c|}{ Sınıflandırılmış ürün gruplarında gidilen mağazaya göre yerli ürün önceliği } \\
\hline $\begin{array}{l}\text { 17. Market alışverişinde yerli ürün } \\
\text { gittiğim yerde yoksa o ürünü başka } \\
\text { yerde ararım. }\end{array}$ & & & & & & ,693 & & & & & \\
\hline $\begin{array}{l}\text { 18. Mağaza alışverişinde yerli ürün } \\
\text { gittiğim yerde yoksa o ürünü başka } \\
\text { yerde ararım. }\end{array}$ & & & & & & ,837 & & & & & \\
\hline $\begin{array}{l}\text { 19.Pahalı ve lüks ürün alışverişinde } \\
\text { yerli ürün gittiğim yerde yoksa o } \\
\text { ürünü başka yerde ararım. }\end{array}$ & & & & & & ,761 & & & & & \\
\hline
\end{tabular}




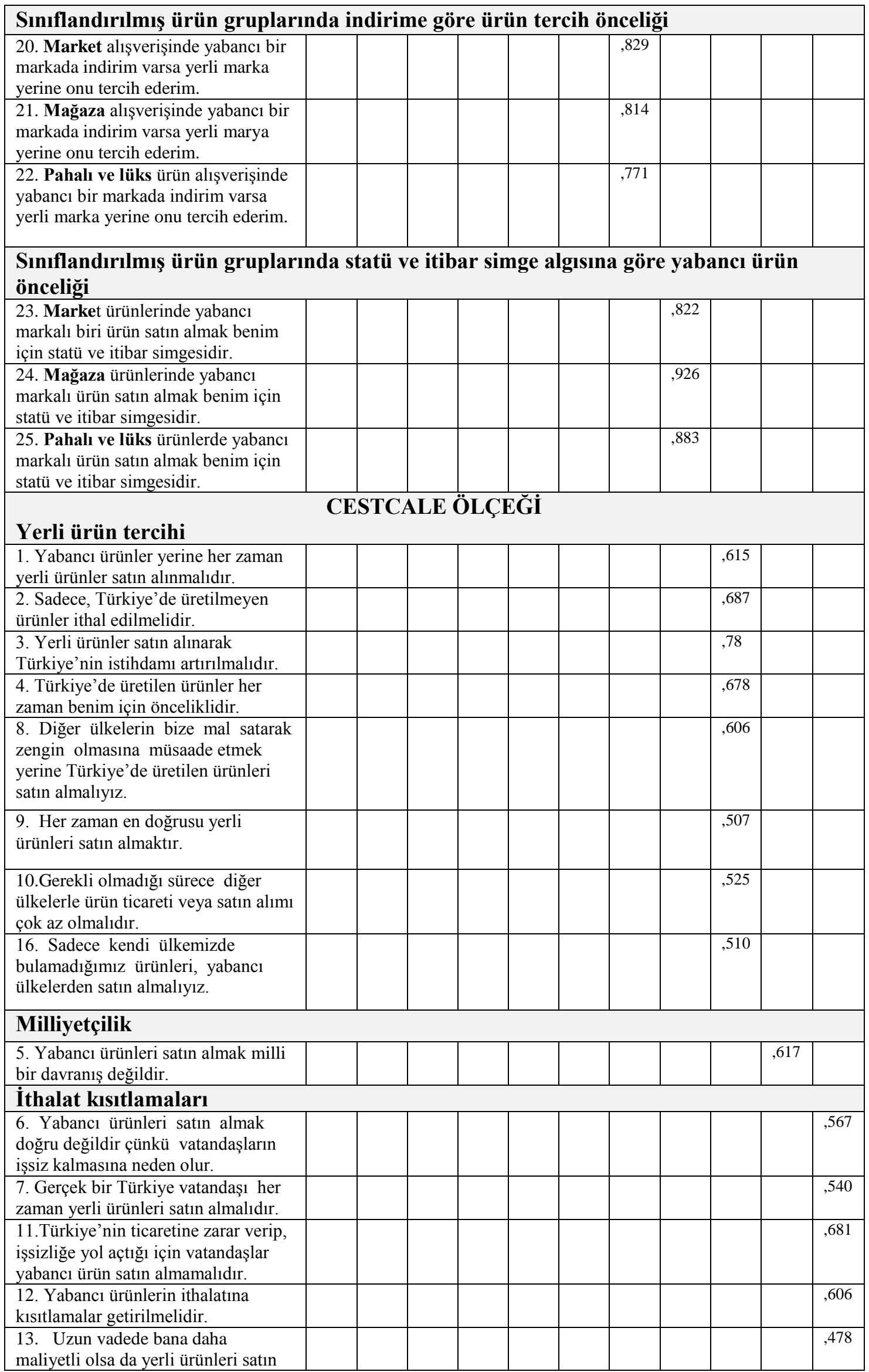




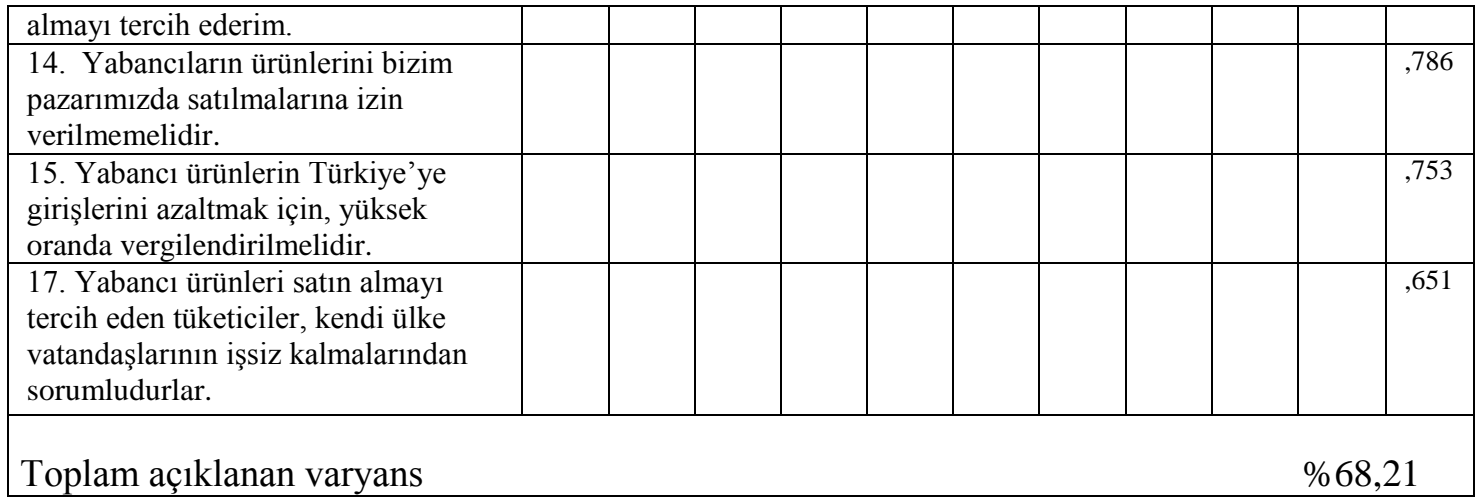

Varimax döndürme yöntemli faktör analizi sonuçlarına göre, çalışmada kullanılan anket sorularının 11 alt boyuttan oluştuğu tespit edilmiş olup, bu faktörler ile açıklanan toplam varyans \%68,21 bulunmuştur. 1-2-3-4 nolu önermeler "yabancı ürün yargısı" olarak isimlendirilen faktör 1'i oluşturmaktadır. 5-6-7-8 numaralı önermeler "yabancı ürün satın alma niyeti” olarak isimlendirilen faktör 2'yi oluşturmaktadır. 9-10 numaralı önermler "menşe ülke etkisi" olarak isimlendirilen faktör 3'ü oluşturmaktadır. 11-12-13 numaralı önermeler "sınıflandırılmış ürün grupların da yerli ürün önceliğgi” olarak isimlendirilen faktör 4 'ü oluşturmaktadır. 1415-16 numaralı önermeler "sınıflandırılmış ürün gruplarında kaliteye göre yerli ürün önceliği” olarak isimlendirilen faktör 5'i oluştumaktadır. 17-18-19 numaralı önermelerden oluşan "sınıflandırılmış ürün gruplarında gidilen mağazaya göre yerli ürün önceliği”" olarak isimlendirilmiş faktör 6'yı oluşturmaktadır. 20-21-22 numaralı önermeler "sınıflandırılmış ürün gruplarında indirime göre ürün tercih önceliği" olarak isimlendirilmiş faktör 7'yi oluşturmaktadır. 23-24-25 numaralı önermeler “sınıflandırılmış ürün gruplarında statü ve itibar simge algısına göre yabancı ürün önceliği” olarak isimlendirilmiş faktör 8'i oluşturmaktadır. Cestcale ölçeği incelendiğinde; 1-2-3-4-8-9-10-16 numaralı önermeler "yerli ürün tercihi” olarak isimlendirilmiş faktör 9'u oluşturmaktadır. 5 numaralı önerme "milliyetçilik" ile isimlendirilen faktör 10 'u oluşturmaktadır. 6-7-11-12-13-14-15-17 numaralı önermeler "ithalat kısıtlamaları" olarak isimlendirilen faktör 11'i oluşturmaktadır. 


\subsection{HIIPOTEZLERIN TESTİ}

\subsubsection{Demografik Özellikler ile Etnosentrizm Arasındaki İlişki}

Çalışmanın bu bölümünde, literatürde bir çok ülkede defalarca araştırılmış olan ve farklı bölgelerde, farklı kültürlerde farklı sonuçlar bulunan demografik özellikler ile etnosentrik eğilimler ilişkisi incelenecektir.

\subsubsection{Y Kuşağının Cinsiyetleri ile Etnosentrik Eğilim Düzeyleri Arasındaki İlişki}

Hipotez 1.a: Etnosentrik eğilim düzeyleri, cinsiyete bağlı olarak farklılaşmaktadır.

Hipotez kapsamında cinsiyete göre etnosentrik eğilim düzeyleri, arasında bir fark olup olmadığını belirlemek için Pearson Ki-Kare Testi kullanılmıştır.

Tablo 25 Cinsiyete Göre Etnosentrik Eğilim Düzeylerinin Değerlendirilmesi

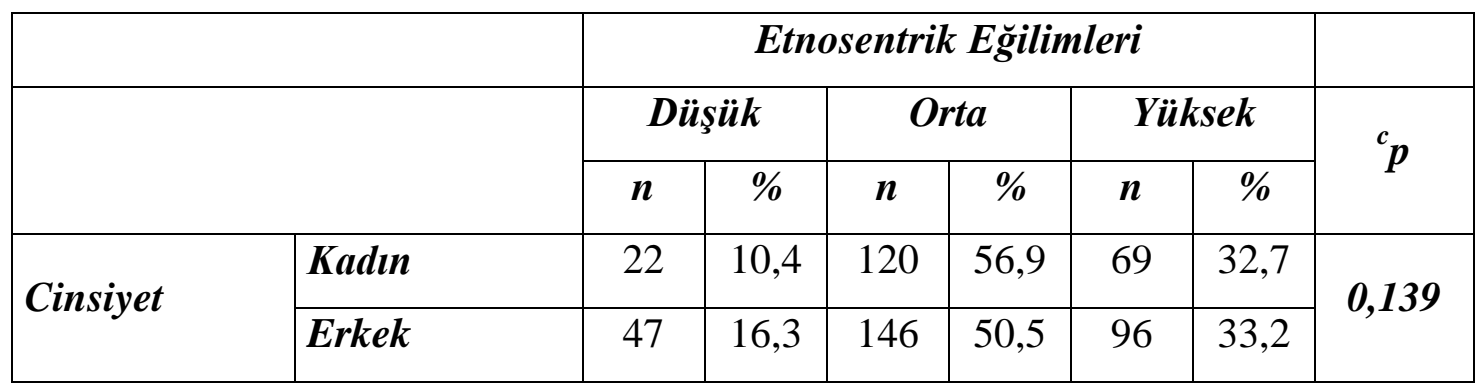

${ }^{c}$ Pearson Ki-Kare Testi

Y kuşağında yer alan katılımcıların cinsiyete göre Etnosentrik eğilim düzeyleri, istatistiksel olarak anlamlı farklılık göstermemektedir ( $p>0,05)$. Cinsiyet ile etnosentrizim arasındaki ilişkinin incelendiği bazı araştırmalarda kadınların erkeklere kıyasla daha etnosentrik eğilime sahip olduğu sonucunu ortaya konulmaktadır (Sharma vd. 1995). Bunun sebebi olarak kadınların daha muhafazakâr ve vatansever ayrıca bir gruba bağlılığı ve uyumu daha yüksek olduğu belirtilmektedir. Yapılan bazı araştırmalarda ise cinsiyet ile etnosentrizim arasında herhangi bir farklılık bulunmamıştır (Balabanis vd,. 2001). Afyonkarahisarda yaşayan Y kuşağı katılımcılarınında cinsiyetleri ile etnosentrik eğilim düzeyleri 
arasında bir farklılık bulunmadığı sonucuna varılarak Balabanis vd,,'nin buldukları sonuç desteklenmiştir. Yapılan çalışmalar bölge olarak farklı yerlerde uygulandığı için buradan şu sonuç çıkarılabilir cinsiyet ile etnosentriz arasındaki ilişki kültürden kültüre veya ülkeden ülkeye farklılık gösterebilmektedir.

\subsubsection{Medeni Durumları ile Etnosentrik Eğilim Düzeyleri Arasındaki İlişki}

Hipotez 1.b. Etnosentrik eğilim düzeyleri, medeni duruma bağlı olarak farklılaşmaktadır

Hipotez kapsamında medeni duruma göre etnosentrik eğilim düzeyleri arasında bir fark olup olmadığını belirlemek için Pearson Ki-Kare Testi kullanılmıştır.

Tablo 26 Medeni Duruma Göre Etnosentrik Eğilim Düzeylerinin Değerlendirilmesi

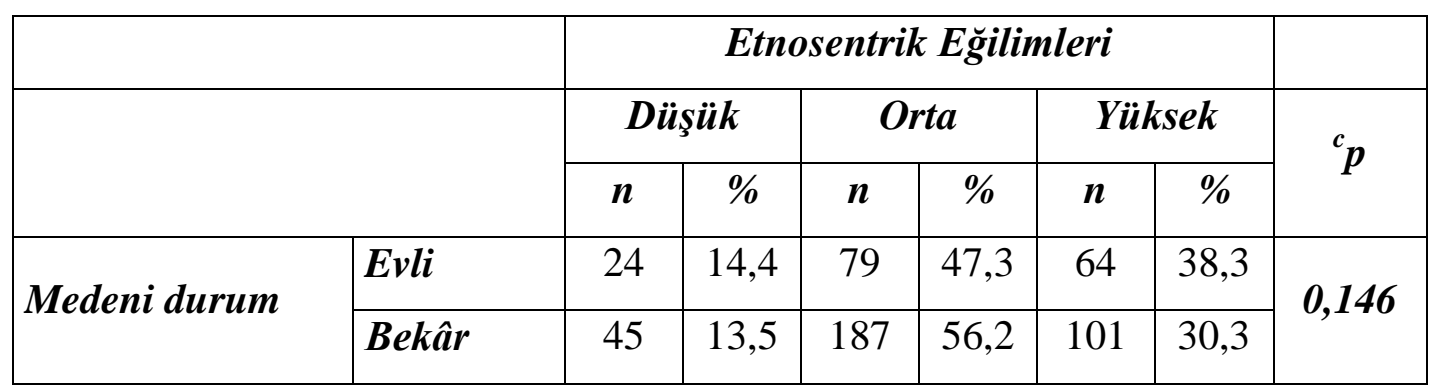

${ }^{c}$ Pearson Ki-Kare Testi

Y kuşağında yer alan katılımcıların medeni durumlarına göre etnosentrik eğilim düzeyleri istatistiksel olarak anlamlı farkl1lık göstermemektedir ( $p>0,05$ 


\subsubsection{Yurt Dışına Çıkma Durumu ile Etnosentrik Eğilim Düzeyleri Arasındaki İlişkisi}

Hipotez 1.c. Etnosentrik eğilim düzeyleri, yurt dışına çıkma durumuna bağlı olarak farklılaşmaktadır.

Hipotez kapsamında yurt dışına çıkma duruma göre etnosentrik eğilim düzeyleri arasında bir fark olup olmadığını belirlemek için Pearson Ki-Kare testi kullanılmıştır.

Tablo 27 Yurt Dışına Çıkma Durumuna Göre Etnosentrik Eğilimlerinin Değerlendirilmesi

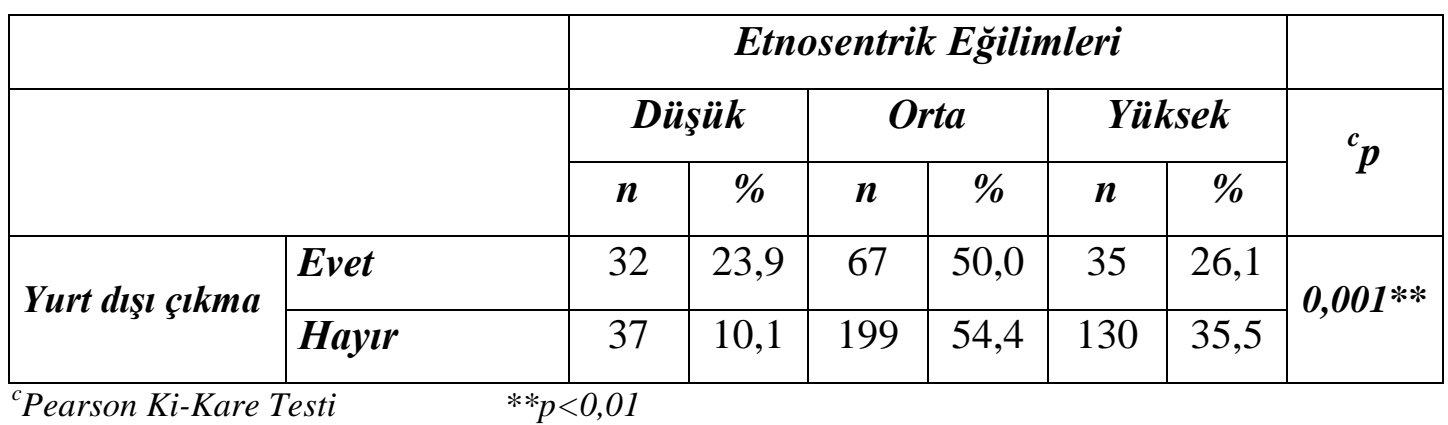

Y kuşağında yer alan katılımcıların yurt dışına çıkma durumuna göre etnosentrik eğilim düzeyleri istatistiksel olarak anlamlı farklılık göstermektedir $(\mathrm{p}=0,001 ; \mathrm{p}<0,01)$. Yurt dışın çıkan katılımcıların düşük etnosentrik eğilime sahip olma oranları yüksek bulunmuştur. Afyonkarahisarda yaşayan Y kuşağı üyelirinin \%73,2 gibi büyük bir çoğunluğunun yurt dişına çıkmadığı sonucuna varılmıştır. Çıkanların ise etnosentrik eğilim düzeyleri zayıf bulunmuştur. Kişilerin yurt dışında bulunmaları, onlara farklı ülke kültürlerini tanıma ve çeşitli ürün deneme imkanı sunmaktadır. Bu yüzden yabancı ülke ve ürünlerine karşı daha 1lımlı yaklaştıkları için etnsosentrik eğilimlerinin düşük çıktığı söylenebilir. 


\subsubsection{Yaş ile Etnosentrik Eğilim Düzeyleri Arasındaki İlişkisi}

Hipotez 1.d. Etnosentrik eğilim düzeyleri yaşa bağlı olarak farklılaşmaktadır.

Hipotez kapsamında yaşa göre etnosentrik eğilim düzeyleri arasında bir fark olup olmadığını belirlemek için Pearson Ki-Kare Testi kullanılmıştır.

Tablo 28 Yaşa Göre Etnosentrik Eğilim Düzeyleri Değerlendirilmesi

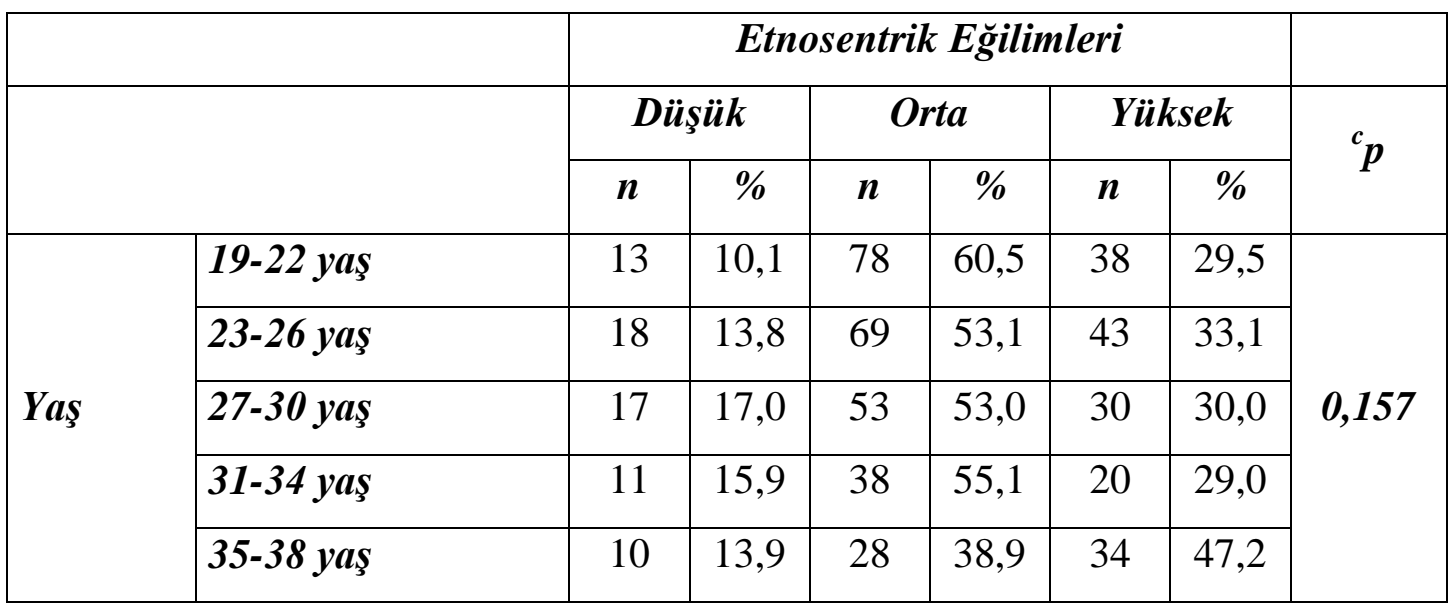

${ }^{c}$ Pearson Ki-Kare Testi

Çalışma 1980 ile 2000 yılları arasında doğan kişileri ele aldığı için yaş olarak kapsamı sınırlıdır. Bu kapsam da kendi arasında 5 gruba ayrılarak 19-22 yaş grubunda yer alan kişiler ile 35-38 yaş grubunda yer alan kişilerin etnosentrik eğilim düzeyleri arasında bir farklılık bulunup bulunmadığını belirlemek amaçalanmıştır. Y kuşağında yer alan katılımcıların yaş durumuna göre etnosentrik eğilimleri istatistiksel olarak anlamlı farklılık göstermemektedir $(\mathrm{p}>0,05)$. Bunun sebebi olarak Afyonkarahisar'da uygulanan bu çalışmanın \%71,8 gibi büyük bir çoğunluğun 30 yaş ve altına uygulanmış olması verilebilir. 


\subsubsection{Eğitim Durumu ile Etnosentrik Eğilim Düzeyleri Arasındaki İlişkisi}

Hipotez 1.e. Etnosentrik eğilim düzeyleri, eğitim durumuna bağlı olarak farklılaşmaktadır.

Hipotez kapsamında eğitim durumuna göre etnosentrik eğilim düzeyleri arasında bir fark olup olmadığını belirlemek için Pearson Ki-Kare Testi kullanılmıştır.

Tablo 29 Eğitim Durumuna Göre Etnosentrik Eğilim Düzeylerinin Değerlendirilmesi

\begin{tabular}{|c|c|c|c|c|c|c|c|c|}
\hline & & \multicolumn{6}{|c|}{ Etnosentrik Ĕ̈ilimleri } & \multirow{3}{*}{${ }^{c} \mathbf{p}$} \\
\hline & & \multicolumn{2}{|c|}{ Düşük } & \multicolumn{2}{|c|}{ Orta } & \multicolumn{2}{|c|}{ Yüksek } & \\
\hline & & $n$ & $\%$ & $n$ & $\%$ & $n$ & $\%$ & \\
\hline \multirow{6}{*}{$\begin{array}{l}\text { Ĕ̆itim } \\
\text { Durumu }\end{array}$} & İlköğretim Mezunu & 1 & 3,7 & 11 & 40,7 & 15 & 55,6 & \multirow{6}{*}{$0,005 * *$} \\
\hline & Lise Mezunu & 17 & 11,1 & 92 & 60,1 & 44 & 28,8 & \\
\hline & Ön Lisans Mezunu & 7 & 9,0 & 35 & 44,9 & 36 & 46,2 & \\
\hline & Lisans Mezunu & 33 & 16,7 & 104 & 52,5 & 61 & 30,8 & \\
\hline & Yüksek Lisans Mezunu & 5 & 20,0 & 15 & 60,0 & 5 & 20,0 & \\
\hline & Doktora & 6 & 31,6 & 9 & 47,4 & 4 & 21,1 & \\
\hline
\end{tabular}

Y kuşağında yer alan katılımcıların eğitim durumuna göre Etnosentrik eğilim düzeyleri istatistiksel olarak anlamlı farkl1lık göstermektedir $(\mathrm{p}=0,005 ; \mathrm{p}<0,01)$. Düşük eğilim en çok doktorada görülür iken, orta eğilim, lise ve yüksek lisansta ve yüksek eğilim ise ilkokul mezunlarında görülmüştür. Yani Ayfonkarahisar ilinde yaşayan Y kuşağı üyelerinin etnosentrik eğilimleriyle ile eğitim durumu arasında negatif yönlü ilişki bulunmakta olup eğitim düzeyleri arttıkça etnosentrik eğilimlerinin azaldığı görülmektedir. Eğitim durumun yükselmesi ile kişilerin hayat standartlarını değişmesi, daha az tutucu hale gelmesi ve yabancı ürünlere karşı ön yargılarının azalmasının bu duruma etki ettiği söylenebilir. İşler'in (2013) ve Sharma vd.,'nin (1995) yaptıkları çalışmalar incelendiğinde de kişilerin eğitim durumları arttıkça etnosentrik eğilim düzeylerinin azaldığı sonucuna varılmış olup bulunan sonuç literatür ile desteklenmiştir. 


\subsubsection{Meslek Grupları ile Etnosentrik Eğilim Düzeyleri Arasındaki İlişkisi}

Hipotez f: Etnosentrik eğilim düzeyleri, meslek gruplarına bağlı olarak farklılaşmaktadır.

Hipotez kapsamında meslek gruplarına göre Etnosentrik eğilim düzeyleri arasında bir fark olup olmadığını belirlemek için Pearson Ki-Kare Testi kullanılmıştır.

Tablo 30 Meslek Gruplarına Göre Etnosentrik Eğilim Düzeylerinin Değerlendirilmesi

\begin{tabular}{|c|c|c|c|c|c|c|c|c|}
\hline & \multicolumn{6}{|c|}{ Etnosentrik Eğilimleri } & \multirow{3}{*}{${ }^{c} \mathbf{p}$} \\
\hline & & \multicolumn{2}{|c|}{ Düşük } & \multicolumn{2}{|c|}{ Orta } & \multicolumn{2}{|c|}{ Yüksek } & \\
\hline & & $n$ & $\%$ & $n$ & $\%$ & $n$ & $\%$ & \\
\hline \multirow{5}{*}{ Meslek } & Kamu & 12 & 13,5 & 40 & 44,9 & 37 & 41,6 & \multirow{5}{*}{0,020} \\
\hline & $\ddot{O ̈ z e l ~ S e k t o ̈ r ~}$ & 28 & 14,3 & 97 & 49,5 & 71 & 36,2 & \\
\hline & Ev Hanımı & 5 & 15,2 & 18 & 54,5 & 10 & 30,3 & \\
\hline & Öğgrenci & 15 & 9,9 & 97 & 63,8 & 40 & 26,3 & \\
\hline & Diğger & 9 & 30,0 & 14 & 46,7 & 7 & 23,3 & \\
\hline
\end{tabular}

Y kuşağında yer alan katılımcıların mesleklere göre etnosentrik eğilim düzeyleri istatistiksel olarak anlamlı farkl1lık göstermektedir $(\mathrm{p}=0,005 ; \mathrm{p}<0,01)$. Düşük eğilim en yüksek diğer meslek grubunda görülür iken, orta eğilim en yüksek öğrencide ve yüksek eğilim ise en yüksek kamuda görülmüştür. Kamuda çalışanlar devlet memuru oldukları için yabancı ürün kullanımının yerli ekonomiye zarar vermesi ve bu durumun kendi bütçelerine de yansıyabileceği düşüncesi olduğu söylenebilir. 


\subsubsection{Aylık Gelir Durumu ile Etnosentrik Eğilim Düzeyleri Arasındaki İlişkisi}

Hipotez 1.g. Etnosentrik eğilimleri, aylık gelir durumlarına bağlı olarak farklılaşmaktadır.

Hipotez kapsamında aylık gelir durumlarına göre etnosentrik eğilim düzeyleri arasında bir fark olup olmadığını belirlemek için Pearson Ki-Kare Testi kullanılmıştır.

Tablo 31 Aylık Gelir Durumlarına Göre Etnosentrik Eğilim Düzeylerinin Değerlendirilmesi

\begin{tabular}{|c|c|c|c|c|c|c|c|c|}
\hline & \multicolumn{6}{|c|}{ Etnosentrik Ĕğilimleri } & \multirow{3}{*}{$\mathbf{c} p$} \\
\hline & & \multicolumn{2}{|c|}{ Düşük } & \multicolumn{2}{|c|}{ Orta } & \multicolumn{2}{|c|}{ Yüksek } & \\
\hline & & $n$ & $\%$ & $n$ & $\%$ & $n$ & $\%$ & \\
\hline \multirow{5}{*}{ Aylık Gelir } & 1500 TL ve alt & 21 & 11,5 & 115 & 62,8 & 47 & 25,7 & \multirow{5}{*}{$0,004 * *$} \\
\hline & 1501-3000 TL & 23 & 13,7 & 81 & 48,2 & 64 & 38,1 & \\
\hline & $3001-4500 \mathrm{TL}$ & 12 & 16,7 & 28 & 38,9 & 32 & 44,4 & \\
\hline & $4501-6000 T L$ & 5 & 10,0 & 28 & 56,0 & 17 & 34,0 & \\
\hline & $6000 T L$ ve üzeri & 8 & 29,6 & 14 & 51,9 & 5 & 18,5 & \\
\hline
\end{tabular}

Y kuşağında yer alan katılımcıların aylık gelire göre etnosentrik eğilimleri istatistiksel olarak anlamlı farklılık göstermektedir ( $p=0,005 ; p<0,01)$. Düşük eğilim, $6000 \mathrm{TL}$ ve üzeri gelire sahip olanlarda görülmektedir. Bu durumun sebebi olarak kişilerin gelir durumu arttıkça yaşam standartlarının ve yurt dışı seyahatlarının artacağı birçok ürünü deneme imkanına sahip olacağı böylece yabancı ürünlere karşı daha açık fikirli olacağı öngörülebilir. Orta eğilim, 1500 TL ve altı gelire sahip olanlarda görülmüştür. Bu kesimin ürün satın alırken çok fazla seçme imkanına sahip olmadıkları, yerli veya yabancı olamasından ziyade bütçelerine uygun olanı aldıkları için etnosetrik eğilimlerinin orta düzeyde çıktığı söylenebilir. Yüksek eğilim, 30014500 TL gelire sahip olanlarda görülmüştür. Bu duruma sebep olarak 3000-4500 gelir aralığına sahip kişilerin genellikle kamu görevlisi yani devlet memuru oldukları için yabancı ürün kullanımının yerli ekonomiye zarar vermesi ve bu durumun kendilerine de yansıyabilmesi düşüncesi ile tercih etmedikleri söylenebilir. Yapılan 
çalışmalar incelendiğinde gelir durumu ile etnosentik eğilim arasında negatif yönlü ilişki olduğu biri artarken diğerinin azalacağı sonucuna varılmıştır (Good ve Huddleston 1995, Sharma 1995).

\subsubsection{Y Kuşağının Etnosentrik Eğilim Düzeyleri ile Ürün Yargısı ve Satın Alma Niyeti Arasındaki İlişki}

Hipotez 2: Yabancı ürün yargısı ve satın alma niyeti, etnosentrik eğilim düzeylerine bağlı olarak farklılaşmaktadır.

Hipotez kapsamında etnosentrik eğilim düzeylerine göre ürün yargısı ve satın alma niyet puanı arasında bir fark olup olmadığını belirlemek için One-WayAnova kullanılmıştır.

Tablo 32 Etnosentrik Eğilim Düzeylerine Göre Ürün Yargısı ve Satın Alma Niyet Değerlendirilmesi

\begin{tabular}{|c|c|c|c|c|c|}
\hline & \multicolumn{3}{|c|}{ Etnosentrik Eğilimleri } & \multirow[b]{2}{*}{${ }^{b} p$} \\
\hline & & $\begin{array}{l}\text { Düşük } \\
(n=69)\end{array}$ & $\begin{array}{c}\text { Orta } \\
(n=266)\end{array}$ & $\begin{array}{c}\text { Yüksek } \\
(n=165)\end{array}$ & \\
\hline \multirow{2}{*}{$\begin{array}{l}\text { Urïn Yargıst ve } \\
\text { Satın Alma Niyet } \\
\text { Puant }\end{array}$} & $O r t \pm S D$ & $3,15 \pm 0,9$ & $3,03 \pm 0,70$ & $3,20 \pm 0,80$ & \multirow{2}{*}{0,083} \\
\hline & Min-Max (Medyan) & $1,13-5(3)$ & $1,50-5(3)$ & $1-5(3,1)$ & \\
\hline
\end{tabular}

${ }^{b}$ One-WayAnova Test

Y kuşağında yer alan katılımcıların etnosentrik eğilim düzeylerine göre ürün yargısı ve satın alma niyeti istatistiksel olarak anlamlı farklılık göstermemektedir ( $p>0,05)$. Bunun sebebi olarak Afyonkarahisar'da yaşayan Y kuşağı üyelerinin ürün değerlendirmesi yaparken ürünleri kalite, fiyat, dayanıklılık gibi fonksiyonlarına göre değerlendirdikleri, yabancı ürün kullanımının ülke ekonomisine zarar verdiğini veya ahlahi açıdan milliyetçi duygulara ters düştügünü savunmadıkları söylenebilir. 


\subsubsection{Y Kuşağının Etnosentrik Eğilim Düzeyleri ile Market Ürünleri Satın Alma Davranışı Arasındaki İlişkisi}

Hipotez 3: Market ürünleri satın alma davranış1, etnosentrik eğilim düzeylerine bağlı olarak farklılaşmaktadır.

Hipotez kapsamında etnosentrik eğilim düzeylerine göre market ürünleri satın alma davranışı arasında bir fark olup olmadığını belirlemek için One-WayAnova kullanılmıştır.

Tablo 33 Etnosentrik Eğilim Düzeylerine Göre Market Ürünleri Değerlendirilmesi

\begin{tabular}{|c|c|c|c|c|c|}
\hline & \multicolumn{3}{|c|}{ Etnosentrizm Eğilimleri } & \multirow[b]{2}{*}{${ }^{b} p$} \\
\hline & & $\begin{array}{l}\text { Düşük } \\
(n=69)\end{array}$ & $\begin{array}{c}\text { Orta } \\
(n=266)\end{array}$ & $\begin{array}{c}\text { Yüksek } \\
(n=165)\end{array}$ & \\
\hline \multirow{2}{*}{$\begin{array}{l}\text { Market Ürünleri } \\
\text { Marka Sadakati } \\
\text { Puant }\end{array}$} & $\operatorname{Ort} \pm S D$ & $2,64 \pm 0,94$ & $3,27 \pm 0,64$ & $3,55 \pm 0,66$ & \multirow[b]{2}{*}{$0,001 * *$} \\
\hline & $\begin{array}{l}\text { Min-Max } \\
\text { (Medyan) }\end{array}$ & $1-5(2,6)$ & $1,80-5(3,2)$ & $1-5(3,4)$ & \\
\hline
\end{tabular}

${ }^{b}$ One-WayAnova Test

Y kuşağında yer alan katılımcıların, etnosentrik eğilim düzeylerine göre market ürünleri satın alma davranışı istatistiksel olarak anlamlı farklılık göstermektedir $(\mathrm{p}=0,001 ; \mathrm{p}<0,01)$. Yapılan ikili karşılaştırmalara göre etnosentrik eğilimi düşük olan katılımcıların market ürünleri satın alma davranışı, orta $(p=0,014)$ ve yüksek $(p=0,001)$ eğilimlere göre düşük olması istatistiksel olarak anlamlı bulunmuştur. Bu durumun sebebi olarak düşük etnosentrik eğilim sergileyen kişilerin yabancı ürün kullanımında herhangi bir sakınca görmediği hatta kalite olarak daha iyi algıladıkları söylenebilir. Orta ile Yüksek etnosentrik eğilimleri arasında istatistiksel olarak anlamlı farklılık saptanmamıştır $(\mathrm{p}>0,05)$. 


\subsubsection{Y Kuşağının Etnosentrik Eğilim Düzeyleri ile Mağaza Ürünleri Satın Alma Davranışı Arasındaki İlişkisi}

Hipotez 4: Mağaza ürünleri satın alma davranışı, etnosentrik eğilim düzeylerine bağlı olarak farklılaşmaktadır.

Hipotez kapsamında etnosentrik eğilim düzeylerine göre mağaza ürünleri satın alma davranışı arasında bir fark olup olmadığını belirlemek için OneWayAnova kullanılmıştır.

Tablo 34 Etnosentrik Eğilim Düzeylerine Göre Mağaza Değerlendirilmesi

\begin{tabular}{|c|c|c|c|c|c|}
\hline & \multicolumn{3}{|c|}{ Etnosentrik Eğilimleri } & \multirow[b]{2}{*}{${ }^{b} p$} \\
\hline & & $\begin{array}{l}\text { Düşük } \\
(n=69)\end{array}$ & $\begin{array}{c}\text { Orta } \\
(n=266)\end{array}$ & $\begin{array}{c}\text { Yüksek } \\
(n=165)\end{array}$ & \\
\hline \multirow{2}{*}{$\begin{array}{l}\text { Mağaza } \\
\text { Ürünleri Marka } \\
\text { Sadakati Puanı }\end{array}$} & $O r t \pm S D$ & $2,53 \pm 0,92$ & $3,14 \pm 0,58$ & $3,53 \pm 0,70$ & \multirow[b]{2}{*}{$0,001 * *$} \\
\hline & $\begin{array}{l}\text { Min-Max } \\
\text { (Medyan) }\end{array}$ & $1-5(2,6)$ & $1,20-5(3,2)$ & $2-5(3,4)$ & \\
\hline
\end{tabular}

Y kuşağında yer alan katılımcıların Etnosentrik eğilim düzeylerine göre mağaza ürünleri satın alma davranış puanı istatistiksel olarak anlamlı farklılık göstermektedir $(p=0,001 ; p<0,01)$. Yapılan ikili karşılaştırmalara göre etnosentrik eğilimi düşük olan katılımcıların mağaza ürünleri satın alma davranışının, orta $(p=0,010)$ ve yüksek $(p=0,001)$ eğilimlere göre düşük olması istatistiksel olarak anlamlı bulunmuştur. Kişilerin etnosentrik eğilim düzeyleri azaldıkça yabancı ürün kullanma eğilimleri artmaktadır. Çünkü kişi ürün değerlendirmesi yaparken kalite, güvenilirlik, dayanıklılık, fiyat gibi faktörleri baz almakta ve üründen sağladığı faydaya baktmaktadır. Bu yüzden Afyonkarahisar'da yaşayan Y kuşağı üyelerinin, yabancı ürün kullanımında herhangi bir sakınca görmemekte olduğu söylenebilir. Orta ile yüksek etnosentrik eğilimleri arasında istatistiksel olarak anlamlı farklılık saptanmamıştır $(p>0,05)$. 


\subsubsection{Y Kuşağının Etnosentrik Eğilim Düzeyleri ile Pahalı ve Lüks Ürün Satın Alma Davranışı Arasındaki İlişkisi}

Hipotez 5: Pahalı ve lüks ürün satın alma davranış puanı, etnosentrizm eğilim düzeylerine bağlı olarak farklılaşmaktadır.

Hipotez kapsamında etnosentrizm eğilim düzeylerine göre pahalı ve lüks ürün satın alma davranış puanı arasında bir fark olup olmadığını belirlemek için OneWayAnova kullanılmıştır.

Tablo 35 Etnosentrik Eğilim Düzeylerine Göre Pahalı ve Lüks Ürün Değerlendirilmesi

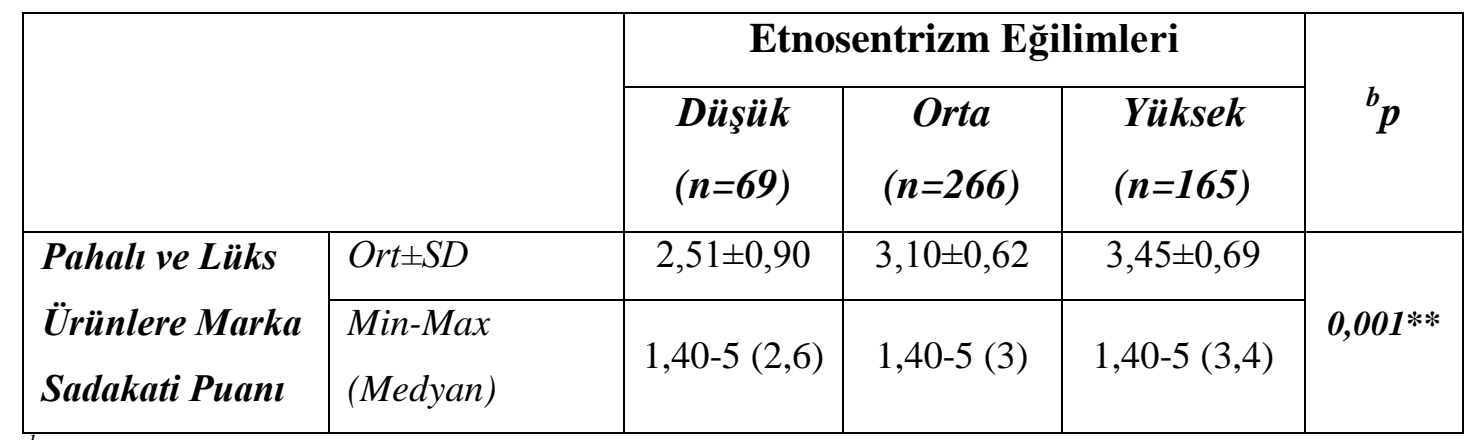

${ }^{b}$ One-WayAnova Test

Y kuşağında yer alan katılımcıların etnosentrik eğilim düzeylerine göre pahalı ve lüks ürün satın alma davranış puanı istatistiksel olarak anlamlı farklılık göstermektedir $(\mathrm{p}=0,001 ; \mathrm{p}<0,01)$. Yapılan ikili karşılaştırmalara göre etnosentrik eğilimi düşük olan katılımcıların pahalı ve lüks ürün satın alma davranışı, orta $(p=0,012)$ ve yüksek ( $p=0,001)$ eğilimlere göre düşük olması istatistiksel olarak anlamlı bulunmuştur. Afyonkarahisar'da yaşayan düşük etnosentrik eğilime sahip Y kuşağı üyerinin pahalı ve lüks ürün gruplarında, yabancı ürün kullanımının herhangi bir sakıncası olmadığı düşüncesindelerdir. Bu durumun sebebi olarak, etnosentrik eğilim düzeyleri azaldıkça yabancı ürün kullanma eğilimlerinin artması söylenebilir. Orta ile yüksek etnosentrik eğilim düzeyleri arasında istatistiksel olarak anlamlı farklılık saptanmamıştır ( $p>0,05)$. 


\subsubsection{Menşe Ülke Etkisi ile Yabancı Ürün Yargısı Satın Alma Niyeti Arasındaki İlişki}

Hipotez 6: Yabancı ürün yargısı satın alma niyeti, menşe ülke etkisi önermelerine katılma kararına göre farklılık gösterir.

Hipotez kapsamında yabancı ürün yargısı satın alma niyeti, menşe ülke etkisi önermelerine katılma kararına göre bir farklılık olup olmadığını belirlemek için OneWayAnova kullanılmıştır.

Tablo 36 Menşe Ülke Etkisi Önerme 1'e Göre Ürün Yargısı ve Satın Alma Niyeti Değerlendirilmesi

\begin{tabular}{|c|c|c|c|c|c|}
\hline & \multirow[b]{2}{*}{ Seçenekler } & \multirow[b]{2}{*}{$n$} & \multicolumn{2}{|c|}{$\begin{array}{c}\ddot{U} \text { rün Yargısı Ve Satın } \\
\text { Alma Niyet Puanı }\end{array}$} & \multirow{2}{*}{${ }^{b} p$} \\
\hline & & & $O r t \pm S D$ & $\begin{array}{l}\text { Min-Max } \\
\text { (Medyan) }\end{array}$ & \\
\hline \multirow{5}{*}{$\begin{array}{lr}\text { “Ürünün } & \text { ait } \\
\text { olduğu } & \text { ülke, } \\
\text { kalitesi } & \\
\text { hakkında fikir } \\
\text { verir” }\end{array}$} & $\begin{array}{l}\text { Kesinlikle } \\
\text { katılmıyorum }\end{array}$ & 36 & $2,61 \pm 0,95$ & $1,13-5(2,56)$ & \multirow{5}{*}{$0,001 * *$} \\
\hline & Katılmıyorum & 74 & $2,93 \pm 0,72$ & $1,63-5(2,88)$ & \\
\hline & Kararsızım & 102 & $3,08 \pm 0,72$ & $1,63-5(3,13)$ & \\
\hline & Katıliyorum & 197 & $3,13 \pm 0,66$ & $1-5(3,13)$ & \\
\hline & Kesinlikle katıliyorum & 91 & $3,43 \pm 0,95$ & $1,63-5(3,13)$ & \\
\hline
\end{tabular}

Y kuşağında yer alan katılımcıların "Ürünün ait olduğu ülke, kalitesi hakkında fikir verir" sorusuna verdikleri yanıtlara göre ürün yargısı ve satın alma niyeti arasında istatistiksel olarak anlamlı farklılık saptanmıştır $(p=0,001 ; p<0,01)$. Yapılan ikili karşılaştırmalara göre kesinlikle katılmıyorum diyenlerin ürün yargısı ve satın alma niyeti, katıliyorum $(p=0,009)$ ve kesinlikle katıliyorum $(p=0,001)$ diyenlere göre düşük olması istatistiksel olarak anlamlı bulunmuştur $(p<0,01)$. Diğer gruplar arasında istatistiksel olarak anlamlı farklılık bulunmamıştır ( $\mathrm{p}>0,005)$. 
Tablo 37 Menşe Ülke Etkisi Önerme 2'ye Göre Ürün Yargısı ve Satın Alma Niyeti Değerlendirilmesi

\begin{tabular}{|c|c|c|c|c|c|}
\hline & \multirow[b]{2}{*}{ Seçenekler } & \multirow[b]{2}{*}{$n$} & \multicolumn{2}{|c|}{$\begin{array}{c}\text { Ürün Yargisı Ve Satın } \\
\text { Alma Niyet Puanı }\end{array}$} & \multirow{2}{*}{${ }^{b} p$} \\
\hline & & & $O r t \pm S D$ & $\begin{array}{l}\text { Min-Max } \\
\text { (Medyan) }\end{array}$ & \\
\hline $\begin{array}{rr}\text { “Ürün } & \text { satın } \\
\text { alırken } & \text { nerede }\end{array}$ & $\begin{array}{l}\text { Kesinlikle } \\
\text { katılmıyorum }\end{array}$ & 36 & $2,96 \pm 1,09$ & $1,38-5(2,88)$ & \multirow{5}{*}{$0,001 *$} \\
\hline üretildiğini & Katılmıorum & 74 & $2,76 \pm 0,49$ & $1,38-4,38(2,75)$ & \\
\hline \multirow{3}{*}{$\begin{array}{l}\text { ögrrenmek için } \\
\text { etiketine } \\
\text { bakarım" }\end{array}$} & Kararsızım & 102 & $3,11 \pm 0,72$ & $1,63-5(3,13)$ & \\
\hline & Katıliyorum & 197 & $3,12 \pm 0,69$ & $1-5(3)$ & \\
\hline & Kesinlikle katıllyorum & 91 & $3,28 \pm 0,94$ & $1,13-5(3,13)$ & \\
\hline
\end{tabular}

Y kuşağında yer alan katılımcıların "Ürün satın alırken nerede üretildiğini öğrenmek için etiketine bakarım" sorusuna verdikleri yanıtlara göre ürün yargısı ve satın alma niyeti arasında istatistiksel olarak anlamlı farklılık saptanmıştır ( $p=0,001$; $\mathrm{p}<0,01)$. Yapılan ikili karşılaştırmalara göre katılmıyorum diyenlerin ürün yargısı ve satın alma niyeti, kesinlikle katılıyorum diyenlere göre düşük olması istatistiksel anlamlı bulunmuştur $(\mathrm{p}=0,001 ; \mathrm{p}<0,01)$. Diğer gruplar arasında istatistiksel olarak anlamlı farklılık bulunmamıştır ( $\mathrm{p}>0,005)$.

\subsubsection{Menşe Ülke Etkisi ile Etnosentrik Eğilim Düzeyi Arasındaki İlişki}

Hipotez 7: Etnosentik eğilim düzeyleri menşe ülke etkisi önermelerine katılma kararına göre farklılık gösterir.

Hipotez kapsamında Etnosentik eğilim düzeyleri menşe ülke etkisi önermelerine katılma kararına göre bir fak olup olmadığını belirlemek için Pearson Ki-Kare Testi kullanılmıştır. 
Tablo 38 Menşe Ülke Etkisi Önerme 1'e Göre Etnosentrik Eğilim Düzeyleri Değerlendirilmesi

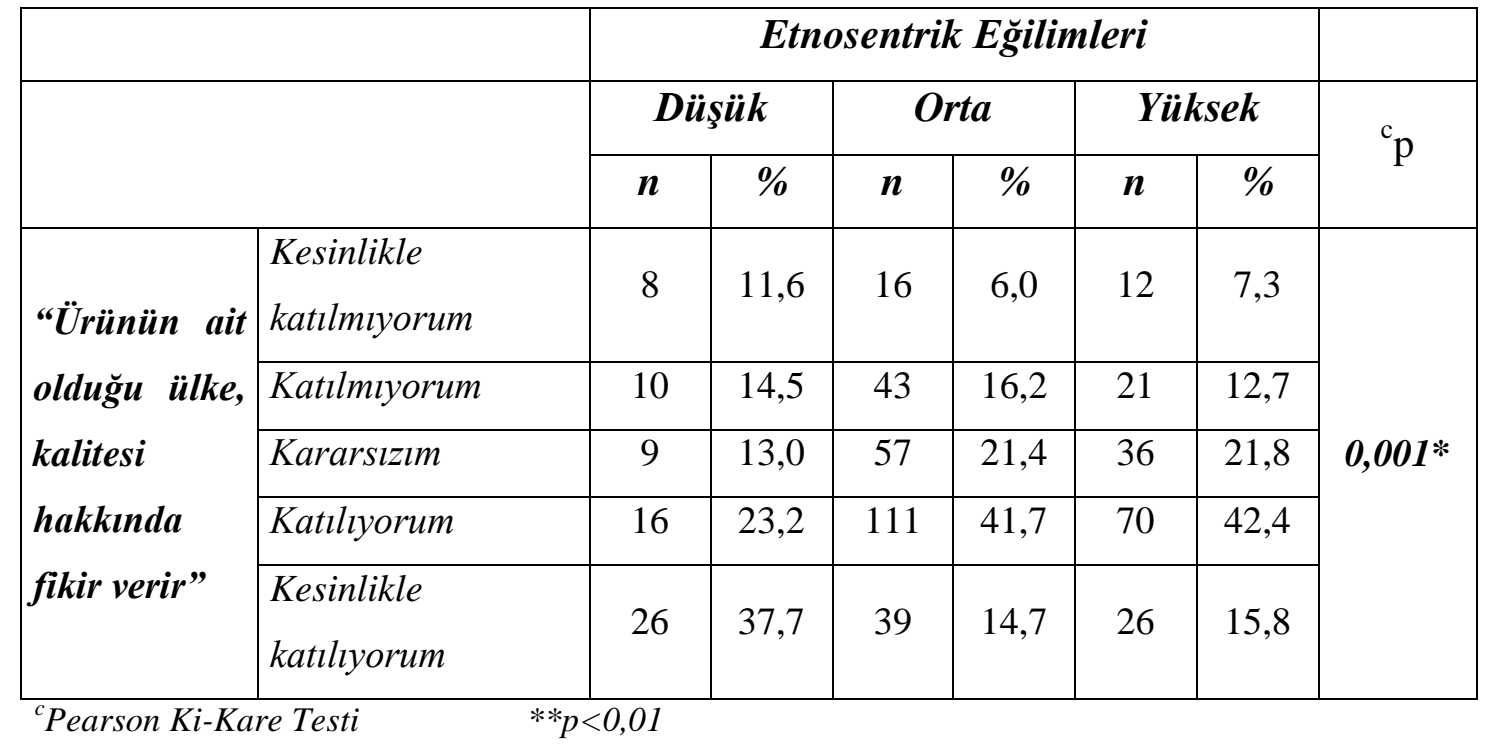

Y kuşağında yer alan katılımcıların etnosentrik eğilim düzeylerine göre "Ürünün ait olduğu ülke, kalitesi hakkında fikir verir" soruna verilen yanıtların arasında istatistiksel olarak anlamlı farklılık saptanmıştır $(p=0,001 ; p<0,01)$. Düşük eğilimde olan katılımcılar kesinlikle katılıyorum yanıtını vermiş iken, orta ve yüksek eğilimdeki katılımcılar katılıyorum yanıtını vermiştir. Genel olarak Afyonkarahisar ilinde yaşayan Y kuşağı üyelerinin bir ürün satın alırken üretildiği ülke kalitesi hakkında fikir verir düşüncesine katılarak, menşe ülke etkisine dikkat ettikleri görülmektedir. 
Tablo 39 Menşe Ülke Etkisi Önerme 2'ye Göre Etnosentrik Eğilim Düzeyleri Değerlendirilmesi

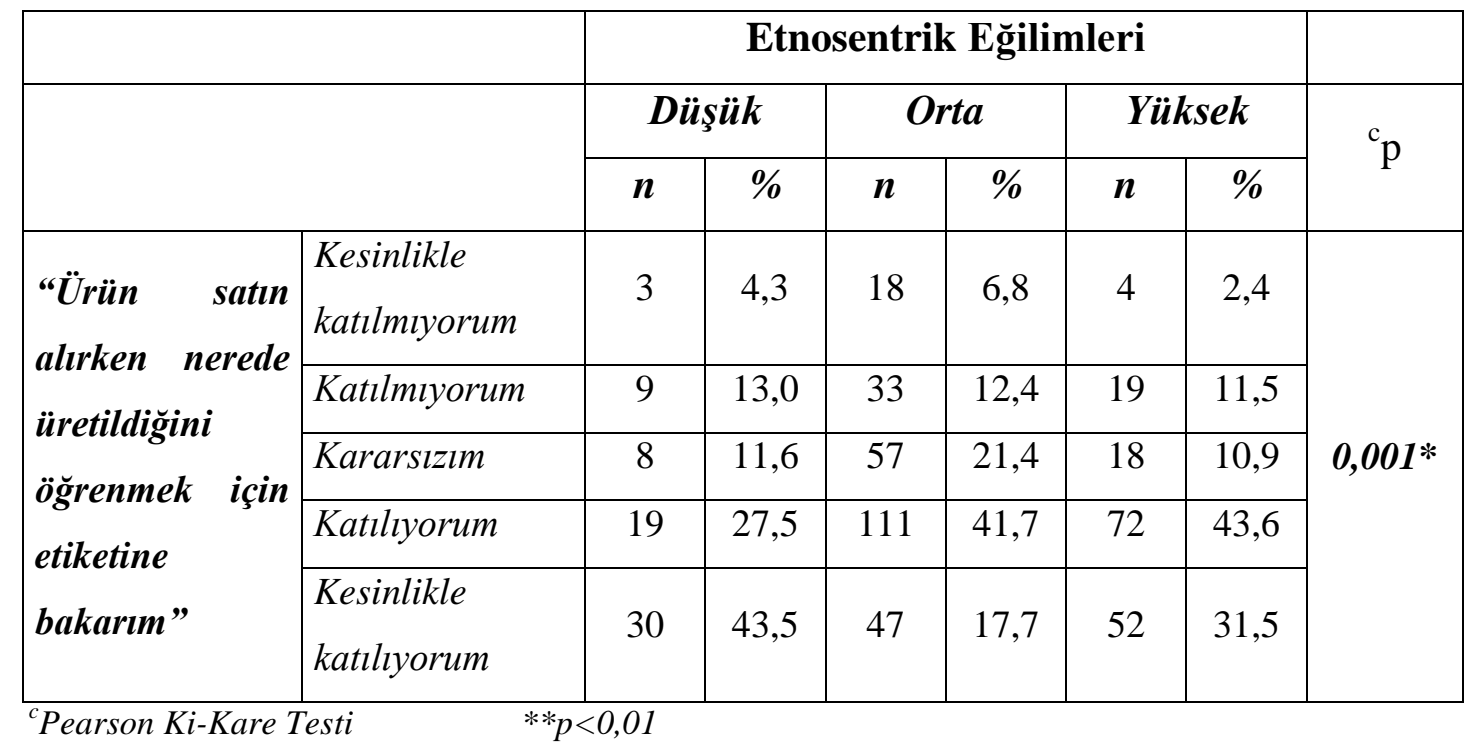

Y kuşağında yer alan katılımcıların etnosentrik eğilim düzeylerine göre "Ürün satın alırken nerede üretildiğini öğrenmek için etiketine bakarım” sorusuna verilen yanıtların arasında istatistiksel olarak anlamlı farklılık saptanmıştır $(\mathrm{p}=0,001$; $\mathrm{p}<0,01)$. Düşük eğilimde olan katılımcılar kesinlikle katılıyorum yanıtını vermiş iken, orta ve yüksek eğilimdeki katılımcılar katılıyorum yanıtını vermiştir. Buradan Afyonkarahisar ilinde yaşayan Y kuşağı üyelerinin, ürün satın alırken menşe ülkesini öğrenmek amacı ile etiketlerine özellikle baktıkları ve bu durumun onlar için önem arz ettiği görülmektedir. 


\subsubsection{Araştırma Hipotezleri Kabul/Red Durumu}

Yapılan anallizler sonucunda elde edilen bulgular doğrultusunda hipotezlerşn kabul veya red edilme durumu aşağıdaki tabloda gösterilmiştir.

Tablo 40 Hipotez Test Sonuçları

\begin{tabular}{|l|c|c|}
\hline \multicolumn{1}{|c|}{ HíPOTEZLER } & P & KABUL/RED \\
\hline $\begin{array}{l}\text { Hipotez 1.a: Etnosentrizm eğilim düzeyleri, cinsiyete } \\
\text { bağlı olarak farklılaşmaktadır. }\end{array}$ & 0,139 & Red \\
\hline $\begin{array}{l}\text { Hipotez 1.b: Etnosentrizm eğilim düzeyleri, medeni } \\
\text { duruma bağlı olarak farklılaşmaktadır }\end{array}$ & 0,146 & Red \\
\hline $\begin{array}{l}\text { Hipotez 1.c: Etnosentrizm eğilim düzeyleri yurt dışına } \\
\text { çıma durumuna bağlı olarak farklılaşmaktadır. }\end{array}$ & 0,001 & Kabul \\
\hline $\begin{array}{l}\text { Hipotez 1.d: Etnosentrizm eğilim düzeyleri yaşa bağlı } \\
\text { olarak farklılaşmaktadır. }\end{array}$ & 0,157 & Red \\
\hline $\begin{array}{l}\text { Hipotez 1.e: Etnosentrizm eğilim düzeyleri eğitim } \\
\text { durumuna bağlı olarak farklılaşmaktadır. }\end{array}$ & 0,005 & Kabul \\
\hline $\begin{array}{l}\text { Hipotez 1.f: Etnosentrizm eğilim düzeyleri meslek } \\
\text { gruplarına bağlı olarak farklılaşmaktadır. }\end{array}$ & 0,020 & Kabul \\
\hline $\begin{array}{l}\text { Hipotez 1.g: Etnosentrizm eğilim düzeyleri aylık gelir } \\
\text { durumlarına bağlı olarak farklılaşmaktadır. }\end{array}$ & 0,004 & Kabul \\
\hline $\begin{array}{l}\text { Hipotez 2: Yabancı ürün yargısı ve satın alma niyeti } \\
\text { etnosentrik eğilim düzeylerine bağlı olarak } \\
\text { farklılaşmaktadır. }\end{array}$ & 0,083 & Red \\
\hline $\begin{array}{l}\text { Hipotez 3: Market ürünleri satın alma davranışı, } \\
\text { etnosentrik eğilim düzeylerine bağlı olarak } \\
\text { farklılaşmaktadır. }\end{array}$ & 0,001 & Kabul \\
\hline $\begin{array}{l}\text { Hipotez 4: Mağaza ürünleri satın alma davranışı, } \\
\text { etnosentrizm eğilim düzeylerine bağlı olarak } \\
\text { farklılaşmaktadır. }\end{array}$ & 0,001 & Kabul \\
\hline $\begin{array}{l}\text { Hipotez 5: Pahalı ve lüks ürün satın alma davranışı, } \\
\text { etnosentrizm eğilim düzeylerine bağlı olarak } \\
\text { farklılaşmaktadır. }\end{array}$ & 0,001 & Kabul \\
\hline $\begin{array}{l}\text { Hipotez 6: Yabancı ürün yargısı satın alma niyeti, menşe } \\
\text { ülke etkisi önermelerine katılma kararına göre farklılık } \\
\text { gösterir. }\end{array}$ & 0,001 & Kabul \\
\hline $\begin{array}{l}\text { Hipotez 7: Etnosentrik eğilim düzeyleri, menşe ülke etkisi } \\
\text { önermelerine katılma kararına göre farklılık gösterir. }\end{array}$ & 0,001 & Kabul \\
\hline
\end{tabular}




\section{SONUÇ}

Küreselleşmenin ortaya çıkardığ 1 yeni ekonomi yapılanması, yeni ve farklı teknolojiler, aşırı rekabet ortamı gibi kavramlar günümüz dünyasının ekonomik işleyişine damga vuran kavramlar olarak karşımıza çıkmaktadır. Bu kavramlar pazardaki rekabet ortamının çok büyük bir seviyeye ulaştığını bizlere anlatmaktadır. İşletmeler de bu rekabet ortamına uyum sağlamak için kendi aralarında anlaşma yapmış gibi davranmaktalardır. Bu gelişmeler de günümüzde herkesin birbirini takip ettiği bir ortam doğurmuştur. Bu ortam içerisinde insanlar, fikirler, hizmetler, ürünler ve getirilen çözümlerle ilgili araştırma, analiz ve yenilik ihtiyacı ortaya çıkmıştır ve günden güne bu ihtiyaç artmaktadır.

Günümüz piyasasında maliyetler, rekabet edebilmenin ve rekabet ederken de avantajlar sağlamanın belirleyici etkeni olma özelliğini kaybetmiştir. Çünkü piyasa şartları çok hızlı değişimler geçirmeye başlamış hatta saat hızında gerçekleşen değişiklikler piyasada etkili olmaya başlamıştır. Değişen piyasa şartları ile birlikte pazardaki ihtiyaçların iyi analiz edilip pazarlama yöneticileri tarafından piyasanın geleceğine yön verilmesi gerekmektedir. $\mathrm{Bu}$ noktadan hareketle de pazarlama yöneticilerinin mercek altına alıp incelemesi gereken olgulardan birisi de tüketicilerin bir markaya/ürüne ilişkin tutum ve tercihlerinin o ürünün imal edildiği ülke imajının etkisiyle değişiklik gösterebileceği gerçeğidir. $\mathrm{Bu}$ gerçeklik de etnosentrizm kavramının önemini ortaya çıkarmaktadır.

Etnosentrizm kavramı bu çalışmanın temelini oluşturmakta olup farklı yönleriyle incelenmeye çalışılmıştır. Çalışmada yer alan ve etnosentrizm kavramının tanımlarının yapıldığı birinci bölümden özetle bu kavramın kişinin sosyolojik ve kişisel olarak bazı değer ve tutumları bakımından kendine en yakın olan grubu benimseyip o gruba aitlik hissinin oluşması, grubun tüm özelliklerinin diğer gruplardan üstün olduğuna inanıp ön planda tutması ve diğer grupları değerlendirirken kendi grubunu esas alarak grubunun özelliklerine göre değerlendirilmesi gerektiği söylenebilir. Özellikle etnosentrizm eğilimi yüksek olan tüketicilerin yabancı marka ve ürünlere ilişkin bakış açısının yurtdışı pazarlara açılan işletmeleri ne şekilde etkileyeceği önemli bir tartışma konusudur. 
Çalışmada Afyonkarahisar ilinde yaşayan Y kuşağı üyelerinin demografik özellikleri ile etnosentrik eğilimleri arasındaki ilişki incelenmiştir. Bu kuşak üyelerinin yerli ve yabancı ürünlere karşı etnosentrik eğilim düzeyleri belirlenip market, mağaza ve pahalı -lüks olarak kategorize edilmiş ürünlere karşı tutum ve davranışları incelenerek etnosetntrizm ile ilişkisine bakılmıştır.

Çalışmanın birinci bölümü genel olarak etnosentrizm kavramı, etnosentrizm eğilimine sahip olan tüketicilerin özellikleri, tüketici etnosentrizmi ve bu olgunun işletme ve pazarlama açısından önemi incelenmiştir. Ayrıca bu incelemeler yapılırken konu genel çerçevesine bağlı olarak tüketici etnosentrizminin Pazarlamanın 4P si olarak adlandırılan ürün, fiyat, tutundurma ve dağıtım üzerindeki etkileri, tüketici etnosentrizmini etkileyen faktörlerin neler olduğu incelenmiştir. $\mathrm{Bu}$ incelemeler de; demografik, sosyo psikolojik, ekonomik ve politik faktörler sınıfları altında irdelenmiştir. Çalışmanın birinci bölümünün sonlarında tüketici etnosentrizminin ülke menşei ile ilişkisine değinilmiş olup bu bağlamda bu ilişkilerin ve etkilerin ölçümünde kullanılan Cetscale ölçeği anlatılmıştır.

Çalışmanın ikinci bölümü araştırma konusunu oluşturan $Y$ kuşağ çerçevesinde oluşturulmuştur. Öncelikli olarak kuşak kavramının tanımlarının incelenmesi, ayrıntılı bir şekilde bu kavramın açıklanması, kuşakların sınıflandırmalarının ve tarih aralıklarının anlatılması, sınıflandırma yapılan kuşakların kişisel özelliklerinin anlatılması ile birlikte kavrama açıklık getirilmiştir. Çalışmanın analiz kısmına geçiş aşamasını oluşturan ikinci bölümde kuşak sınıflandırmaların tamamına değinilmiş fakat genel olarak $X, Y$ ve $Z$ kuşakları, özelinde de Y kuşağı anlatılmış ve özellikleri ortaya konulmuştur. Günümüze en yakın iki kuşak olan $\mathrm{X}$ ve $\mathrm{Y}$ kuşaklarının, temelde ise $\mathrm{Y}$ kuşağının özellikleri, tüketim alışkanlıkları ve bu kuşağın pazarlamada ki önemi de yine bu bölümde anlatılmıştır.

Çalışmanın üçüncü bölümü istatistiki araştırmaların ve sonuçlarının ayrıntılı olarak incelendiği son bölümdür. Bu bölümde ortaya konulan araştırmalar ve veriler Afyonkarahisar ilinde yaşayan 1980 ile 2000 yılları arasında doğan Y kuşağı üyelerine uygulanan anketlerden oluşmakla birlikte 500 kişiye uygulanmıştır. Anket soruları 5'li likert ölçeği kullanılarak 4 bölümden oluşmaktadır. 1. bölümde 
katılımcıların demografik özelliklerine ilişkin sorular yer almaktadır. 2. bölüm, 1998 yılında Klein ve Ettenson çalışmasında kullanılan yerli ve yabancı ürünlere karşı ürün yargı ve satın alma niyetini ölçen sorulardan oluşmaktadır. Ayrıca menşei ülke etkisi çalışılan birçok araştırmada yer alan katılımcıların bir ürünü almadan önce ürün ile ilgili bilgi edinmek için hangi ülkede üretildiğini öğrenmek amacı ile etiketine bakma sıklığını ölçen sorulardan oluşmaktadır. 3. bölüm, market ürünleri (gıda, temizlik, kozmetik, kişisel bakım) daha çok gündelik hayatta kullandığımız kolay erişim sağlayabileceğimiz, mağaza ürünleri (giyim, ayakkabı, aksesuar, çanta, beyaz eşya, ev elektroniği, mobilya küçük ev aletleri, oyun ve eğlence setleri) daha çok satın alma sırasında bizi düşündüren beğenmeli ürünler, pahalı ve lüks ürünler (otomobil, ev, pahalı elektronik ürünler, pahalı mobilyalar, sanatsal ürünler, mücevher, koleksiyon ürünleri) daha çok satın almadan önce üzerinde uzun süre düşündüğümüz, kolayca erişim sağlayamadığımız lüks ürünlerden oluşturulmuştur. Katılımcıların yerli ve yabancı ürünlere karşı tutum ve davranışlarını kategorize edilen ürün grupları için değerlendirilmesi istenilen (Arı, 2007, Özmen, 2004) çalışmalarından uyarlanmış sorulardan oluşmaktadır. Anketin son bölümde ise katılımcıların etnosentrizm eğilim düzeylerini belirlemek amacı ile güvenilirliği ve geçerliliği test edilmiş Tüketici Etnosentrik Eğilim Ölçeği “CETSCALE (Consumer Ethnocentric TendencyScale)" kullanılmıştır.

Yapılan araştırmanın demografik istatistikleri incelendiğinde, katılımcıların \%57,8 oranında yoğun olarak erkeklerden oluştuğu, yaş olarak ise \%71,8'ni 30 yaş ve altının oluşturduğu bu yüzden genellikle bekar katılımcıların yer aldığı görülmektedir. Eğitim durumları incelendiğinde \%39,6 oranında lisans mezunu oldukları görülmektedir. Bunun sebebi olarak 30 yaş ve altı katılımcılar yoğun olması söylenebilir. Demografik faktörler ile etnosentrizm eğilim düzeyleri arasındaki ilişki incelendiğinde gelir, eğitim düzeyi ve meslekler arasında istatistiksel olarak anlamlı bir ilişki saptanmakla beraber eğitim düzeyi ve gelir arttıkça etnosentrizm eğilimlerin azaldığı görülmektedir. İnsanların gelirlerinin artması sonucu daha iyi eğitim alabilme imkanına sahip olmakta, yurtdışına özgürce seyahat edebilimekte ve daha fazla ürün deneme imkanı sahip olmaktadır. Bunun sonucunda da, dünya görüşlülükleri ve yabancı kültürlere açıklıklarının artması beklenebilir. Diğer demografik faktörler ile etnosetzim eğilimler arasında istatistiksel olarak 
herhangi bir fark saptanmamıştır. Araştırmaya katılan Y kuşağı katılımcılarının çoğunun yurt dışında bulunmadıkları, bulunanların ise etnosentrizm eğilimlerinin düşük olduğu saptanmıştır.

Yabancı ürün yargısı ve satın alma niyeti ölçeği incelendiğinde ise Afyonkarahisar ilinde yaşan Y kuşağı katılımcılarının yabancı ürünleri yerli ürünler göre teknoloji, tasarım ve dayanıklılık bakımından daha üstün algıladıkalrı ve yabanc1 ğrğnlere karşlı ön yargıları olmayıp, yabancı ürün satın alma eğilimi sergilemektelerdir. Kalite bakımından yerli ürünlerin kalitesi artırıldığı takdirde yerli ürün satın alma eğilimi sergileyecekleri hatta yerli ürün için daha fazla para ödemeyi bile göze aldıkları görülmektedir. Aynı zamanda yabancı ürünlere karşı ön yargı ile yaklaşmadıkları ve satın alma niyetlerinin olabileceği yönünde değerler saptanmıştır.

Menşe ülke ilişkisi incelendiğinde Afyonkarahisar ilinde yaşayan Y kuşağı katılımcılarının ürünün üretilmiş olduğu ülke kalitesi hakkında fikir verir düşüncesine inandıkları, ürün ile ilgili bilgi sahibi olmak için satın alma sırasında ürün etiketine baktıkları sonucuna ulaşılmıştır. Ürün yargısı satın alma niyeti ile menşe ülke arasındaki ilişki incelendiğinde ise istatistiksel olarak anlamlı ilişkisi bulunmuştur. $\mathrm{Bu}$ durumun etnosentrizm ile olan ilişkisine bakıldığında ise istatistiksel olarak farkın olduğu düşük etnosentrizm eğiliminde olan Y kuşağının kesinlikle katıldığ1, orta ve yüksek etnosentrizm eğilimine sahip kişilerinde katıldığı bulguları yer almaktadır. Yani Afynkarahisar'da yaşayan; düşük, orta ve yüksek etnosentriz eğilimine sahip Y kuşağı üyelerinin hepsi ürün satın almadan önce bilgi edinmek amacı etiketine baktığı algısı oluşmaktadır.

Market ürünleri olarak kategorize edilmiş ürün yargılarına ilişkin ise yerli ürünlerin yabanc1 ürünlere göre daha iyi olduğu ve eşit kalitede olan üründe yerli ürün satın alma eğilimi sergiledikleri sonucuna varılmıştır. Satın alacakları ürünün kesinlikle yerli ürün olsun diye ayrı bir çaba sarf etmedikleri ayrıca fiyat faktörüne de önem verip indirimde bir ürün varsa yerli veya yabancı fark etmeksizin tercih etme eğilimine sahip oldukları ve onlar için market ürünlerinde yabancı markalı bir ürün almanın herhangi bir statü sembolü olmadığı sonucuna ulaşılmıştır. Etnosentrik eğilim düzeyleri ile olan ilişki incelendiğinde ise istatistiksel olarak anlamlı farklılık bulunmuştur. Yapılan ikili karşıllaştırmalara göre etnosentrik eğilimi düşük olan 
katılımcıların market ürünleri satın alma davranışı, orta $(p=0,014)$ ve yüksek $(p=0,001)$ eğilimlere göre düşük olması istatistiksel olarak anlamlı bulunmuştur.

Mağaza ürünleri ve pahalı - lüks ürünler olarak kategorize edilmiş ürün yargılarına ilişkin ise yerli ürünleri yabancı ürünlere göre iyi görmedikleri ama aynı kaliteye sahip olduğu takdirde yerli ürün tercih etme eğiliminde oldukları sonucuna varılmıştır. Satın alacakları ürünün kesinlikle yerli ürün olsun diye ayrı bir çaba sarf etmemektelerdir. Ayrıca fiyat faktörüne de önem verip indirimde bir ürün varsa yerli veya yabancı fark etmeksizin tercih etme eğilimine sahip oldukları ve onlar için mağaza ürünlerinde yabancı markalı bir ürün almanın herhangi bir statü sembolü olmadığ1 sonucuna ulaşılmıştır. Etnosentrik eğilim düzeyleri ile olan ilişkisi incelendiğinde istatistiksel olarak anlamlı farklılık bulunmuş olup yapılan ikili karş1laştırmalara göre etnosentrik eğilimi düşük olan katılımcıların mağaza ürünleri satın alma davranış puanının, orta $(p=0,010)$ ve yüksek $(p=0,001)$ eğilimlere göre düşük olması istatistiksel olarak anlamlı bulunmuştur.

Etnosentrizm Cestcale ölçeğine ilişkin soruların dağılımı incelendiğinde, Afyonkarahisar'da yaşayan Y kuşağı katılımcılarının ürün satın almada öncelikli olarak Türkiye de üretilen ürünler olduğu saptanmakla birlikte fiyat faktörüne de önem verdikleri sırf yerli ürün olsun diye satın alacakları ürünün daha maliyetli olma fikrine katılmadıkları sonucuna varılmıştır. Ayrıca yabancı ürün kullanımının Türkiye ticaretine zarar verip işsizliğe yol açtığı düşüncesi savunmaktalardır. Bunun sebebi ise genellikle yaş olarak genç kesimi hedef alan çalışmada, Türkiye'de işsizlik seviyesinin yüksek olduğundan katılımcıların işsizliğe neden olabileceği düşüncesini çağrıştırdığı için bu konuda hassas oldukları yorumu yapılabilir.

Afyonkarahisar'da yaşayan Y kuşağı üyeleri, her ne kadar öncelik olarak kendi ülke ürünlerini satın alma eğiliminde olsalar da yabancı ürünlerin kendi ülkemize girerken yüksek oranda vergilendirilmesi veya girişine kısıtlamalar getirilmesine katılmadıkları bu durumun kendi isteklerine göre herhangi bir yasaklama olmadan tercih etmek istedikleri gözlenmektedir. Genel olarak verilen cevaplar incelendiğinde Afyonkarahisar'da yaşayan $\mathrm{Y}$ kuşağı üyelerinin orta düzeyde etnosentrik eğilime sahip olduğu sonucu çıkmaktadır. Bu durumu bilimsel olarak da kanıtlamak için çoğu çalışmada kullanılan Cestcale ölçeğine verilmiş olan 
cevapları analiz ederken kolaylık sağlaması ve katılımcıların farklı etnosentrik düzeylerini belirlemek amacı ile katılımcıların skorlarına göre düşük, orta ve yüksek olarak 3 grupta ele alınmıştır ve çalışmaya katılanların orta etnosentrik eğilime sahip olduğu sonucuna ulaşılmıştır.

Pazarda büyük bir tüketici grubunu oluşran Y kuşağının yerli ve yabancı ürünlere karşı tutum ve davranışlarının analiz edildiği bu çalışmada Afyonkarahisar'da yaşayan Y kuşağının genel olarak yabancı ürünleri daha kaliteli buldakları için tercih etrikleri, yerli ürünlerin kalitesinin arttırıldığı taktirde yerli ürün tercih etmek istedikleri kanısına varılmıştır. $\mathrm{Bu}$ sonuç ışığında yerli ürün üreticilerinin ürünlerinin özellikle kalite, güvenilirlik ve tektonoloji bakımından yabancı ikamelerle yarışabilecek ölçüde geliştirmeleri, bu durumu pazarlama ve özellikle tutundurma stratejilerinde vurgulamaları, firmaların yabancı ürünlerle rekabet edebilmesine yardımcı olacaktır. Bu çalışma konu ve yöntem bakımından benzer konuda araştırma yapacak araştırmacılara rehber niteliği taşımakla birlikte literatüre çeşitlilik kazandırmıştır. Çalışma Afyonkarahisar ili ile sınırlı olduğu için yorumlamalar Afyonkarahisar ve benzer iller düzeyinde bir genelleme yapmaya olanak sağlamaktadır Gelecek çalışmalar farklı illeri de dahil ederek Türkiye genelinde sonuçlara varılabilir ayrıca diğer kuşaklar ile karşılaştırmali analiz yaparak aralarındaki görüş farklılıklarını ortaya koyabilirler. 


\section{KAYNAKÇA}

Acılıoğlu, İ. (2017). “İş” te Y Kuşă̆l, Ankara: Elma Yayınevi, 2.Basım.

Ağırdır, B. (2013). Y Kuşă̆ı İnovasyon Araştırması, Deloitte Eğitim Vakfi.

Ajzen, I. and Fishbein, M. (1975). Belief, Attitude, Intention and Behavior: An Introduction to Theory and Research. Reading, MA: Addison-Wesley Publishing Company.

Akdemir, A., Konakay, G., Demirkaya, H., Noyan, A., Demir, B., Ăg, C. Pehlivan, Ç., ve diğer. (2013). Y kuşağının Kariyer Algısı, Kariyer Değişimi ve Liderlik Tarzı Beklentilerinin Araştırılması, Ekonomi ve Yönetim Araştırmaları Dergisi, 2 (2), 11- 42.

Akın, M., Çiçek, R., Gürbüz, R. ve Ünal M.E. (2009). Tüketici Etnosentrizmi ve Davranış Niyetleri Arasındaki Farklılı̆̆ın Belirlenmesinde CETSCALE Ölçeği, Ege Akademik Bakış, 9 (2), 490-491.

Aktan, D. (2017). Mindful Consumption and Generatıon Y: Comprehension, Conceptualızatıon, and Communıcatıon, İzmir Ekonomi Üniversitesi, Doktora Tezi, İzmir.

Albayrak, A. ve Özkul, E. (2013). Y Kuşağı Turistlerin Destinasyon İmaj Algıları Üzerine Bir Araştırma. Turkish Studies International Periodical For The Langua-ges, Literature and History of Turkish or Turkic, 8 (6), 15-31.

Altunışık, R., Coşkun, R., Bayraktaroğlu, S. ve Yıldırım, E. (2010). Sosyal Bilimlerde Araştırma Yöntemleri (Spss Uygulamalı), Sakarya: Sakarya Kitabevi, 6. Bask1.

Altuntuğ, N. (2012). Kuşaktan Kuşağa Tüketim Olgusu ve Geleceğin Tüketici Profili, Organizasyon ve Yönetim Bilimleri Dergisi, 4 (1), 203-212.

Arı, E. S. ve Madran, C. (2011). Satın Alma Kararlarında Tüketici Etnosentrizmi ve Menşe Ülke Etkisinin Rolü, Dergi Park, Öneri, 9 (35), 15-33. 
Armağan, E. A. ve Gürsoy, Ö. (2011). Satın Alma Kararlarında Tüketici Etnosentrizmi ve Menşe Ülke Etkisinin Cetscale Ölçeği İle Değerlendirilmesi, Organizasyon ve Yönetim Bilimleri Dergisi, 3 (2), 67-77.

Arı, E. S., (2011). Satın Alma Kararlarında Tüketici Etnosentrizmi ve Menşe Ülke Etkisinin Rolü, Çukurova Üniversitesi Sosyal Bilimler Enstitüsü İşletme Anabilim Dalı, Yüksek Lisans Tezi, Adana.

Asil, H. ve Kaya, İ. (2013). Türk Tüketicilerin Etnosentrik Eğilimlerinin Belirlenmesi Üzerine Bir Araştırma, Ístanbul Üniversitesi İşletme Fakültesi Dergisi, 42 (1), 113-132.

Aslan, A. ve Staub, S. (2015). Kuşak Teorisi ve İç Girişimcilik Üzerine Bir Araştırma, Kafkas Üniversitesi İktisadi ve İdari Bilimler Fakültesi Dergisi 6 (11), 1-24.

Ayhün, S. E. (2013). Kuşaklar Arasındaki Farklılıklar ve Örgütsel Yansımaları, Ekonomi ve Yönetim Araştırmaları Dergisi, 2 (1), 93-112.

Bakawell, C and Mitchell, V. W. (2003). Generation Y Female Consumer Decision Making Styles, International Journal Of Retail \& Distribution Management, 31 (2), 94-106.

Bakırtaş, H, Divanoğlu, S. U. ve Akkaş, C. (2016). Y Kuşağı. Bursa: Ekin Basın Yayın Dağıtım.

Balabanis, G., Diamantopoulos, A., Mueller, R.D. \& Melewar, T. C. (2001). The Impact of Nationalism, Patriotism and Internationalism on Consumer Ethnocentric Tendencies, Journal of Internatıonal Business Studies, 32 (1), 157-175.

Balabanis, G., Diamantopoulos, A., Mueller, R.D. \& Melewar, T. C. (2002), The Relationship Between Consumer Ethnocentrism and Human Values, Journal of Global Marketing, 15 (3/4), 7-37.

Balıkçıŏlu, B. (2008) Tüketici Etnosantrizminin Satın Alma Davranışı Üzerindeki Etkisi: Ankara Örneği, Doktora Tezi, Ankara Üniversitesi Sosyal Bilimler Enstitüsü, Ankara. 
Başgözde, P. ve Bayar, N. A. (2014). Eko Otellerden Hizmet Satın Alımında Kuşaklar Arası Farklılaşmalar Üzerine Bir Çalışma, Sosyoekonomi Dergisi, 23 (24), 118-130.

Batra, R., Ramaswamy, V., Alden, D.L, Steenkamp, E.M., \& Ramachander, S. (2000), Effects of Brand Local and Nonlocal Origin on Consumer Attitudes in Developing Countries, Journal of Consumer Psychology, 9 (2), 83-95.

Bawa, A (2004), Consumer Ethnocentrism: CETSCALE Validation and Measurement of Extent, Vlkalpa, 29(3), 43-57.

Berkman, H. W. and Gilson, C. (1978). Consumer Behavior: Concepts and Strategies, Encino CA: Dickenson Publishing Co., Inc.

Bloomberg Businessweek Türkiye, (2015). Y Kuşağını Anlamak. (25 Ekim - 7 Kasım Özel Ek). ISSN: 1306-2387 35

Broadbridge, A. M.,Maxwell, G. A., \& Ogden, S. M. (2007). 13_2_30: Experiences, Perceptions and Expectations of Retail Employment for Generation Y. Career Development International, 12 (6), 523-544.

Can, P. ve Yiğit, İ. (2017). Sponsorluk Faaliyetlerinde Tüketici Etnosentrizmi, Tüketici Kozmopolitliği, Müsabakalara Katılım ve Sponsor Markasına Tutumun Marka Güvenine Etkisi Üzerine Bir Araştırma, Selçuk Illetişim, 10 (1), 98-119.

Candan, B., Aydın, K. \& Yamamoto, G.T. (2008). A Research On Measuring Consumer Ethnocentrism Of Young Turkısh Customers Purchasing Behaviors, Serbian Journal of Management, 3 (1), 39 - 60.

Caplow, T. (1964). Principles of Organization, Harcourt, New York: Brace and World.

Chen, H. (2010). Advertising and Generational Identity: A Theoretical Model, American Academy of Advertising Conference Proceedings, 132-140.

Cheong A. L. H. (2011). Country of Origin Information, Ethnocentrism and Perceived Quality of Mobile Phones: Experience from the Field, International Review of Business Research Papers, 7 (6), 15-32. 
Crumpacker, M. ve Crumpacker, J.M., (2007). Succession Planning and Generational Stereotypes: Should HR Consider Age-Based Values and Attitudes a Relevant Factoror a Passing Fad?, Public Personnel Management, 36 (4), 349-369.

Cleveland, M., Laroche, M., \& Papadopoulos, N. (2009). Cosmopolitanism, Consumer Ethnocentrism, and Materialism: An Eight-Country Study of Antecedents and Outcomes, Journal of International Marketing, 17 (1), 116146.

Çatalkaya, C. (2014). Kariyer 2.0., İstanbul: Optimist Yayınları.

Sertoğlu, A. E. ve Çatlı, Ö. (2017). Genç Tüketicilerin Yabancı ve Türk Ürünlerine İlişkin Tutum ve Tüketici Etnosentrizm Düzeylerini Belirlemeye Yönelik Bir Araştırma, Gazi Üniversitesi İktisadi ve İdari Bilimler Fakültesi Dergisi Gazi Akademi Genç Sosyal Bilimciler Sempozyumu, Özel Sayısı (1-23).

Başol, O. ve Çetin Aydın, G. (2014). X ve Y Kuşağı: Çalışmanın Anlamında Bir Değişme Var mı?. Elektronik Meslek Yüksekokulları Dergisi, 1-15.

Dedeoğlu, A. O., Savaşçı, İ. \& Ventura, K. (2005). Consumer Ethnocentrısm Portrayed In The Advertısıngs And Meanıngs Actualızed By Consumers: A Case Of Turkey. Asia Pacific Advances in Consumer Research, 6, 274-279.

Demirkaya, H. ,Akdemir A. ,Karaman E. ve Atan, Ö. (2015). Kuşakların Yönetim Politikası Beklentilerinin Araştırılması, İşletme Araştırmaları Dergisi, 7 (1), 186-204.

Deneçli, S. (2015). Markaların Sosyal Medya Yönetimi, İstanbu: Kriter Yayınevi

Dosen, D. O., Skare, V., \& Krupka, Z. (2007), Assessments of Country of Origin and Brand Cues in Evaluating a Croatian, Western and Eastern European Food Product, Journal of Business Research, 60, 130-136.

Durvasula, S., Andrews, J. C. \& Netemeyer, R. G. (1997). A Cross Cultural Comparison of Consumer Ethnocentrism in The United States and Russia. Journal of International Consumer Marketing. 9 (4), 73-93. 
Elibol, A. (2013). Tüketici Etnosantrizminin Satın Alma Davranışı Üzerinde Etkisi, Süleyman Demirel Üniversitesi Sosyal Bilimler Enstitüsü İşletme Anabilim Dalı, Yüksek Lisans Tezi, Isparta.

Esen, S. S. (2011). Konaklama İşletmelerinde Müşteri Memnuniyeti ve Etnosentrizmin Müşteri Memnuniyet Düzeyleri Üzerindeki Etkisi (Alanya İlçesi Örneği), İşletme Ana Bilim Dalı Yüksek Lisans Tezi, Karaman.

Ettenson, R. \& Gaeth, G. (1991). Commentary Consumer Perceptions of Hybrid (BiNatioanal) Products, The Journal of Consumer Marketing, 8 (4), 13-18.

Fettahlıoğlu, H. S. ve Sünbül, B. (2015). Tüketici Etnosentrizmi ve Tüketici Husumetinin X,Y,Z Kuşakları Açısından İncelenmesi, Internatonal Journal of Academic Value Studies, 1 (1), 26-45.

Chryssochoidis, G., Krystallis, A. \& Perreas, P. (2007). Ethnocentric Beliefs and Country of Origin (COO) Effect: Impact of Country, Product and Product Attributes on Greek Consumers' Evaluation of Food Products. European Journal of Marketing, 41 (11), 1518 - 1544.

Gilboa, S. \& Vilnai Yavetz, I. (2010). Four Generations of Mall Visitors in Israel: A Study of Mall Activities, Visiting Patterns, and Products Purchased, Journal of Retailing and Consumer Services, 17 (6), 501-511.

Good, L. K. \& Huddleston, P. (1995). Ethnocentrism of Polish and Russian Consumers: are Feelings and Intentions Related?, International Marketing Review, 12 (5), 35-48.

Ha, C. L. (1998). The Influence of Consumer Ethnocentrism and Product Characteristics on Country of Origin Effects: A Comparison Between U.S. Consumers and Korean Consumers, Doktora Tezi, Faculty of the Graduate School of the University of Texas, Arlington.

Hammond, A. R. \& Axelrod, R. (2006). The Evolution of Ethnocentrism, Journal Of Conflict Resolutıon, 50 (6), 926-936.

He, J. \& Wang, C. L. (2015). Cultural İdentity and Consumer Ethnocentrism Impacts on Preference and Purchase of Domestic Versus Import Brands: An Empirical Study in China. Journal of Business Research, 68 (6), 1225-1233. 
Herce, J. (1994). Ethnocentric Tendencies, Marketing Strategy and Import Purchase Behaviour, International Marketing Review, 11 (3), 4-16.

Hofstede, G. (1980). Culture's Consequences: International Differences in Work Related Values. London, Newbury Park: Sage Publications.

Hofstede, G. (1991). Cultures And Organizations: Software Of The Mind. London: McGraw Hill.

Hofstede, G., and Bond, M. H., (1988). The Confucius Connection: From Cultural Roots To Economic Growth. Organizational Dynamicsl, 16 (4), 4-21.

İslamoğlu, A. H. (2009). Sosyal Bilimlerde Araştırma Yöntemleri (Spss Uygulamalı), İzmit: Beta.

İşler, D. B. (2013). Tüketici Etnosentrizmi ve Menşe Ülke Etkisi Ekseninde Satın Alma Kararlarındaki Rolü: Cetscale Ölçeği ile Bir Uygulama, AIB $\ddot{U}$ Sosyal Bilimler Enstitüsü Dergisi, 13 (1), 93-121.

Javalgi, R. G., Khare, V. P., Gross, A. C \& Scherer, R. F. (2005), An Application of the Consumer Ethnocentrism Model to French Consumers, International Business Review, 14, 325-344.

Josiassen, A., Assaf, A. G. \& Karpen, I.O. ( 2011). Consumer Ethnocentrism and Willingness to Buy. International Marketing Review , 28 (6), 627-646.

Kavak, B. ve Gümüşoğlu, L. (2006). The Role Of Ethnocentrism and Lifestyle in Understanding Purchasing İntentions, International Journal of Market Research, 49 (1), 71-94.

Kayabaşı, A., Taşkın, E. ve Kayık, M. (2016), Y Kuşağının Türk ve Yabancı Firmalara Yönelik Algıları: Çok Boyutlu Ölçekleme İle Analizi, Sosyal Bilimler Dergisi, 49, 29-45.

Keleş, H. N. (2011). Y Kuşağı Çalışanlarının Motivasyon Profillerinin Belirlenmesine Yönelik Bir Araştırma, Organizasyon ve Yönetim Bilimleri Dergisi, 3 (2), 129-139. 
Kızıltaş, Ş. (2014). Kültürleşmenin Tüketici Etnosentrizmi Üzerine Etkisini Belirlemeye Yönelik Bir Araştırma, Atatürk Üniversitesi Sosyal Bilimler Enstitüsü İşletme Anabilim Dalı, Doktora Tezi, Erzurum.

Klein, J. G., Ettenson, R. \& Morris, M. D. (1998). The Animosity Model Of Foregin Product Purchase: An Empirical Test İn The People ${ }^{e e}$ Republic of China. Journal of Marketing, 62 (1), 89-101.

Klein, J. G. ve Ettenson, R. (1999). Consumer Animosity And Consumer Ethnocentrism: An Analysis Of Unique Antecedents. Journal Of International Consumer Marketing, 11 (4), 5-24.

Knight, G. A. (1999). Consumer Preferences For Foreign and Domestic Products, Journal of Consumer Marketing, 16 (2), 151-162.

Kotler, P. \& Armstrong, G. (2004). Principles of Marketing, New Jersey: Prentice Hell, 10. Press.

Kotler, P., Kartajaya, H. ve Setiawan, I. (2011). Pazarlama 3.0, Optimist Yayınları, İstanbul.

Kuyucu M. (2014). Y Kuşağı ve Facebook: Y Kuşağının Facebook Kullanım Alışkanlıkları Üzerine Bir İnceleme, Elektronik Sosyal Bilimler Dergisi, 13 (4950), 55-83,

Kuyucu, M. (2017). Y Kuşağı ve Teknoloji: Y Kuşağının İletişim Teknolojilerini Kullanım Alışkanlıkları, Gümüşhane Üniversitesi, İletişim Fakültesi Elektronik Dergi, 5, (2), 845-872.

Küçükemiroğlu, O. (1999). Market Segmentation By Using Consumer Lifestyle Dimensions And Ethnocentrism: An Empirical Study. European Journal of Marketing, 33 (5/6), 470-487.

Kyles, D. (2005) Managing Your Multigenerational Workforce, Strategic Finance, $87(6), 52-55$.

Lancman, M. L. \& Brett, D. L. (2013). Generation Y: Shopping and Entertainment in The Digital Age, Urban Land Institue, Washington, America. 
Lantz, G. \& Loeb, S. (1996). Country Of Origin And Ethnocentrism: An Analysis Of Canadian And American Prefences Using Social İdentity Theoryl, Advances in Consumer Research, 23, 374-378.

Lee, M. Y., Knight, D. \& Kim, Y. K. (2008). Brand Analysis of a US Global Brand in Comparison with Domestic Brands in Mexico, Korea, and Japan. Journal of Product \& Brand Management, 17 (3), 163-174.

Lower, J. (2008). Brace Yourself Here Comes Generation Y, Critical Care Nurse, 28 (5), 80-85, Erişim $\quad$ Tarihi: http://ccn.aacnjournals.org/content/28/5/80.full. pdf?q=generation-y.

Luque Martinez, T., Ibanez Zapata, J. A. \& Barrio Garcia, S. (2000). Consumer Ethnocentrism Measurement: an Assessment of the Reliability and Validity of the CETSCALE in Spain, European Journal of Marketing, 34 (11/12), 1353-1373.

Mannheim, K. (1952). "On the Problem of Generations" In Essays on the Sociology of Knowledge, Trans. Paul Kecskemeti, London, UK: Routledge \& Kegan.

Marketing Türkiye, (2016/2), Sayı:312, ISSN:1303-45700-8 Pazarlamada Hedefimiz Y Kuşağı Bilmeniz Gereken 6 Ana Kural, Erişim Tarihi: 16.02.2018 http://www.marketingturkiye.com.tr/haberler/pazarlamada-hedefiniz-ykusagiysa-bilmeniz-gereken-6-ana-kural/

Marshall, K. P. (1999), Has Technology Introduced New Ethical Problems?, Journal of Business Ethics, 19 (1), 81-90.

Miller, R. K. \& Washington, K. (2011). Consumer Behavior, Richard K. Miller and Associates.

Mucuk, İ. (2017). Pazarlamam İlkeleri, İstanbul: Türkmen Kitabevi, 21.Basım.

Mutlu, H. M., Çeviker, A. ve Çirkin, Z. (2011). Tüketici Etnosentrizmi ve Yabancı Ürün Satın Alma Niyeti: Türkiye ve Suriye Üzerine Karşılaştırmalı Analiz, Sosyo Ekonomi, Ocak-Haziran Sayıs1, 52-73.

Nart, S. (2008), Menşe Ülke Etkisinin Tüketici Algılamaları ve Davranışlarına Yansımaları: İngiltere Pazarında Türk ve Alman Markaların Karşılaştırılması, 
Süleyman Demirel Üniversitesi İktisadi ve İdari Bilimler Fakültesi Dergisi, 13 (3), 153-177.

Noble, M. S., Haytko, D. L. \& Phillips, J. (2009). What Drives College-age Generation Y consumers? Journal of Business Research, 62 (6), 617-628.

O'Cass, A. \& Siahtiri, V. (2013). In Search of Status Through Brands From Western and Asian Origins: Examining the Changing Face of Fashion Clothing Consumption in Chinese Young Adults, Journal of Retailing and Consumer Services, 20 (6), 505-515.

Odabaşı, Y. ve Barış, G. (2017). Tüketici Davranışı, İstanbul: MediaCat, 17.Basım

Okan, E. Y. ve Yalman, N. (2013). Türkiye'de Tartışmalı Reklamlar: Kuşaklar Arası Karşılaştırma, Hacettepe Üniversitesi İktisadi ve İdari Bilimler Fakültesi Dergisi, 31 (2), 135-152.

Okan, M. (2012). Tüketicilerin Etnosentrik Eğilimlerinin Analizi ve Hızlı Tüketim Mallarında Bir Uygulama, Anadolu Üniversitesi Sosyal Bilimler Enstitüsü, Yüksek Lisans Tezi, Eskişehir.

Özbek, M. F. (2005). Geleneksel Toplumlar ve Güven Bağlamında Etnosentrik Eğilim İlişkisi, Türk Dünyası Celalabad Isşletme Fakültesi.

Özçelik, D. G. ve Torlak, Ö. (2011). Marka Kişiliği Algısı ile Etnosentrik Eğilimler Arasındaki İlişki: LEVİS ve MAVİ JEANS Üzerine Bir Uygulama, Ege Akademik Bakış, 11 (3), 361-377.

Özçelik, N. (2015). The Affects Of Corporate Socıal Responsıbılıty On Y Generatıon Consumer Purchase Decision and Social Media Influence, Marmara Üniversitesi Sosyal Bilimler Enstitüsü İngilizce İşletme Anabilim Dalı Üretim Yönetimi ve Pazarlama (İngilizce) Bilim Dalı, Yüksek Lisans Tezi, İstanbul.

Özden, A. T. (2017). Etnosentrik Eğilimin Tüketicilerin Satın Alma Davranışına Etkisi: Doğu Anadolu ve Karadeniz Bölgeleri Üzerine Karşılaştırmalı Analiz, Başkent Üniversitesi İşletme Anabilim Dalı Doktora Tezi, Ankara. 
Özmen, N. (2016). Y Kuşă̆ının İnternet Alışveriş Eğilimleri, Bahçeşehir Üniversitesi Sosyal Bilimler Enstitüsü, Yüksek Lisan Tezi, İstanbul.

Parment, A. (2013). Generation Y vs. Baby Boomers: Shopping Behavior, Buyer Involvement and Implication For Retailing, Journal of Retailing and Consumer Services, 20 (2), 189-199.

Parts, O \& Vida, I. (2011). The Effects of Consumer Cosmopolitanism on Purchase Behavior of Foreign vs. Domestic Products, Managing Global Transitions; Koper, 9 (4), 355-370.

Petra, K. K. (2016). Generation Y Attitudes Towards Shopping: A Comparison of the Czech Republic and Slovakia, Journal of Competitiveness, 8 (1), 38- 54.

Phau, I. \& Cheong, E. (2009). How Young Adult Consumers Evaluate Diffusion Brands: Effects of Brand Loyalty and Status Consumption, Journal of International Consumer Marketing, 21 (2), 109-123.

Reeves, T. C. \& Oh, E. (2008). Generational Differences, in Handbook of Research on Educational Communication and Technology, Spector, J.M.

Sandıkçı, Ö. ve Ekici, A. (2009). Politically Motivated Brand Rejection, Journal of Business Research , 62 (2), 208-217.

Sarı, S., Gürsoy, S. ve Özmen M. (2016). Y Kuşağının Çevrim İçi Satın Alma Davranışları, Bitlis Eren Üniversitesi Sosyal Bilimler Enstitüsü Dergisi, 5(1), 87-104.

Senbir, H. (2004) “ Z Son İnsan M1?”, “O” Kitaplar, İstanbul, 1. Bask1.

Shankarmahesh, M. N. (2006). Consumer Ethnocentrism: an Integrative Review of Its Antecedents and Consequences, International Marketing Review, 23 (2), 146-172.

Sharma, S., Shimp, T. A. \& Shin, J. (1995). Consumer Ethnocentrism, A Test of Antecedents and Moderators, Journal of the Academy of Marketing Science, $23(1), 26-37$.

Shimp, T. A. (1984), Consumer Ethnocentrism: The Concept and a Preliminary Empirical Test, Advances In Consumer Research, 11, 285-290 
Shimp, T.A., \& Sharma, S. (1987), Consumer Ethnocentrism: Construction and Validation of the CETSCALE, Journal of Marketing Research, 24 (3), 280289

Solomon, M. R. (2006). Tüketici Krallı̆̆ının Fethi Markalar Diyarında Pazarlama Stratejileri, Çetinkaya, S (Çev.) İstanbul: Medicat Yayınları.

Solomon, M. R. (2013). Consumer Behavior: Buying, Having and Being. Boston, Pearson.

Sökmen, A. ve Tarakçıoğlu, S. (2010), İşgören Etnosentrizmine Yönelik Bir Uygulama, Işletme Araştırmaları Dergisi, 2 (3), 25-44.

Straus, W., \& Howe, N. (1992). Generations: The History of America's Future, Quill, 1584-2069.

Supphellen, M. \& Rittenburg, T. L. (2001). Consumer Ethnocentrism When Foreign Products Are Better, Psychology \& Marketing,18 (9), 907-927.

Shimp T.A. \& S. Sharma (1987). Consumer Ethnocentrism: Construction and Validation of the CETSCALE, Journal of Marketing Research, 24 (8), 280289.

Kalaycı, Ş. (2009). Spss Uygulamalı Çok Değişkenli İstatistik Teknikleri, Ankara: Asil Yayınevi.

Tavşancıl, E. (2006). Tutumların ölçülmesi ve SPSS ile Veri Analizi, Ankara: Nobel Yayın Dağıtım.

Thelen, S. (2002), Antecedents and Consequences of Consumer Ethnocentrismacross Russia's Three Subcultures, Doktora tezi, Old Dominion University.

Thelen, S., Ford, J. B., \& Honeycutt E. D., (2006), Assessing Russian Consumers Imported Versus Domestic Product Bias, Thunderbird International Business Review. 48, 687-704.

Topçu, U. C.(2014). Tüketicilerin Etnosentrik Tüketim Eğilimleri İle Sosyo-Politik Tutumları Arasındak İlişkiler, Çanakkale On sekiz Mart Üniversitesi Sosyal Bilimler Enstitüsü, Yüksek Lisans Tezi, Çanakkale. 
Triandis, H. C., Bontempo, R., \& Villarel, J. (1988). Individualism And Collectivism: A Crosscultural Perspectives on Self-İngroup Relationships. Journal of Personality and Social Psychology, 54, 323-338.

Tufur, M. (2011). Türkiyenin Y Kuşağı Araştırma Raporu, Conento Mediacat Özel Eki.

Tükel, İ. (2014). Tüketimin Yeni Aktörleri: Y Kuşağ1, Erişim Tarihi: 02.02.2018 http://www.sdergi.hacettepe.edu.tr/makaleler/TuketimYeniAktorYkusagiKA SIM2014.pdf

Türk, A. (2013). Y Kuşağı. İstanbul: Kafekültür Yayıncılık.

Twenge, J. M., 2009. Ben nesli. İstanbul: Kaknus, 3. Bask1.

Ueltschy \& Linda C. (1998), Brand Perceptions as Influenced by Consumer Ethnocentrism and COO Effects, The Journal of Marketing Management, 8 (1), 12-23.

Ünal, D. (2011). Köken Ülke Faktörünün Satın Alma Davranıslarına Etkisi Aydın İlnde Bir Uygulama, Adnan Menderes Üniversitesi Sosyal Bilimler Enstitüsü İsletme Anabilim Dalı, Yüksek Lisans Tezi.

Valentine, D. B. \& Powers, T. L. (2013). Generation Y values and lifestyle segments, Journal of Consumer Marketing, 30 (7), 597-606.

Wang, C. L. \& Chen, Z. X. (2004). Consumer Ethnocentrism and Willingness to Buy Domestic Products in a Devoloping Country Setting: Testing Moderating Effects, Journal of Consumer Marketing, 21 (6), 391-400.

Watson, J. J. \& Wright, K., (2000). Consumer Ethnocentrism And Attitudes Toward Domestic and Foreign Products, Eurpean Journal of Marketing, 34 (9/10), 1149-1166.

Yapraklı, T. Ş. ve Keser, E. (2013). Tüketici Etnosentrizmi: Beyaz Eşya ve İçecek Sektörlerinde Karşılaştırmalı Bir Saha Araştırması, Selçuk Üniversitesi İktisadi ve İdari Bilimler Fakültesi Sosyal ve Ekonomik Araştırmalar Dergisi, $25,385-419$. 
Yarangümelioğlu, D. ve İşler, D. (2014). Marka Bağlılı̆̆ı Ve Etnosentrizm Çerçevesinde Tüketici Satın Alma Davranışlar, Dumlupınar Üniversitesi Sosyal Bilimler Dergisi, 39, 91-110.

Yaşa, E., ve Bozyiğit, S. (2012). Y Kuşağı Tüketicilerinin Cep Telefonu ve GSM Operatörleri Tercihi: Mersin İlindeki Üniversite Öğrencilerinin Tercihlerini Belirlemeye Yönelik Pilot Bir Araştırma. Çă̆ Üniversitesi Sosyal Bilimler Dergisi, 9 (1), 29-46.

Yelkikalan, N. Akatay, A. ve Altın, E. (2010). Yeni Girişimcilik Modeli ve Yeni Nesil Girişimci Profili: İnternet Girişimciliği ve Y, M, Z Kuşağı Girişimci, Süleyman Demirel Üniversitesi. İI.I.B.F. Sosyal ve Ekonomik Araştırmalar Dergisi, 10 (20), 489-506.

Yoo, B. \& Donthu, N. (2005). The Effect of Personal Cultural Orientation on Consumer Ethnocentrism: Evaluations and Behaviors of U.S. Consumers Toward Japanese Products, Journal of International Consumer Marketing, 18 $(1 / 2), 7-44$.

Yüksekbilgili, Z. (2013). Türk Tipi Y Kusağı, Elektronik Sosyal Bilimler Dergisi, 12 (45), 342-353.

Yüksekbilgili, Z (2015). Türkiye'de Y Kuşağının Yaş Aralığı, Elektronik Sosyal Bilimler Dergisi, 14 (33), 259-267. 


\section{EKLER}

EK-1 Araştırmada Kullanılan Anket Formu

\section{Sayın Katılımcı,}

Y kuşağının (1980-2000 yılları arasında doğanlar), etnosentrik eğilimlere göre yerli ve yabancı ürünlere karşı satın alma davranışını ölçmek amacıyla kullanılacak olan bu anket; Afyon Kocatepe Üniversitesi, Sosyal Bilimler Enstitüsü, Üretim Yönetimi ve Pazarlama Anabilim Dalı, Yüksek Lisans programında, Gizem Büyükkalaycı tarafından yüksek lisans tez çalışmasında kullanılmak üzere hazırlanmıştır. Anket ile toplanan veriler gizli kalacak değerlendirme bireysel olarak değil, genel olarak yapılacaktır. Çalışmaya olan katkı ve ayırdığınız zaman için teşekkür ederiz.

\begin{tabular}{|c|c|}
\hline Cinsiyetiniz ( )Kadın ( )Erkek & Medeni durumunuz ( )Evli ( )Bekar \\
\hline 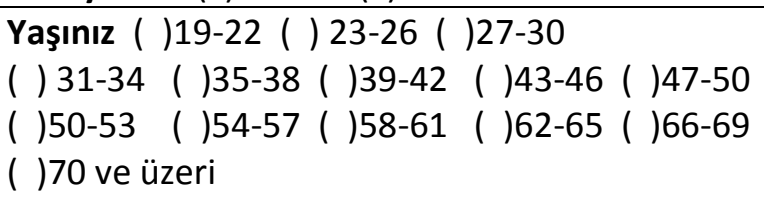 & $\begin{array}{l}\text { Mesleğiniz ( ) Memur ( ) Iş̧̧̧i ( )Esnaf } \\
\text { ( ) Serbest Meslek ( ) Özel Sektör } \\
\text { ( ) Ev Hanımı ( ) Öğrenci } \quad \text { ( )Akademisyen } \\
\text { ( ) Işşiz ( ) Diğer......... }\end{array}$ \\
\hline $\begin{array}{l}\text { Eğitim durumunuz ( )ilkokul Mezunu } \\
\text { ( )Ortaokul Mezunu ( )Lise Mezunu } \\
\text { ( ) Ön Lisans Mezunu } \quad \text { ( ) Lisans Mezunu } \\
\text { ( ) Yüksek Lisans Mezunu () Doktora }\end{array}$ & $\begin{array}{l}\text { Aylık geliriniz ( ) } 1500 \mathrm{TL} \text { ve altı } \\
\text { ( ) 1501-3000 TL ( ) } 3001-4500 \mathrm{TL} \\
\text { ( ) 4501-6000 TL ( ) } 6000 \mathrm{TL} \text { üzeri }\end{array}$ \\
\hline & \\
\hline
\end{tabular}

\begin{tabular}{|c|c|c|c|c|c|}
\hline $\begin{array}{l}\text { Aşağıda yer alan ifadeleri katılma derecenize göre sizin için } \\
\text { en uygun seçeneği işaretleyiniz. } \\
\text { 1.Kesinlikle Katılmıyorum 2.Katılmıyorum 3.Kararsızım } \\
\text { 4.Katılıyorum 5. Kesinlikle Katılıyorum }\end{array}$ & 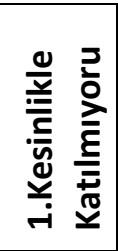 & 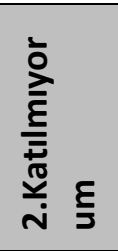 & 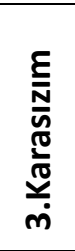 & 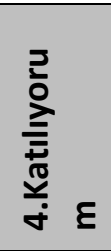 & 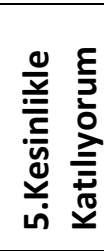 \\
\hline $\begin{array}{l}\text { 1. Yabancı ürünler yerli ürünlere göre teknolojik olarak } \\
\text { daha ileridir. }\end{array}$ & 1 & 2 & 3 & 4 & 5 \\
\hline $\begin{array}{l}\text { 2. Yabancı ürünlerin tasarımı yerli ürünlere göre daha } \\
\text { kullanışlıdır. }\end{array}$ & 1 & 2 & 3 & 4 & 5 \\
\hline 3. Yabancı ürünler yerli ürünlere göre daha dayanıklıdır. & 1 & 2 & 3 & 4 & 5 \\
\hline 4. Yabancı ürünler pahalı olsa bile verilen paraya değerdir. & 1 & 2 & 3 & 4 & 5 \\
\hline $\begin{array}{l}\text { 5. Yabancı bir ürün satın aldığımda kendimi suçlu } \\
\text { hissederim. }\end{array}$ & 1 & 2 & 3 & 4 & 5 \\
\hline 6.Yabancı ürüne sahip olma fikrini sevmiyorum. & 1 & 2 & 3 & 4 & 5 \\
\hline $\begin{array}{l}\text { 7. Biri yerli diğeri yabancı iki ürün kalite bakımından eşit } \\
\text { olsa, yerli ürün için daha fazla para ödeyebilirim. }\end{array}$ & 1 & 2 & 3 & 4 & 5 \\
\hline 8. Asla yabancı ürün satın almam. & 1 & 2 & 3 & 4 & 5 \\
\hline 9. Ürünün ait olduğu ülke, kalitesi hakkında fikir verir. & 1 & 2 & 3 & 4 & 5 \\
\hline $\begin{array}{l}\text { 10. Ürün satın alırken nerede üretildiğini öğrenmek için } \\
\text { etiketine bakarım. }\end{array}$ & 1 & 2 & 3 & 4 & 5 \\
\hline
\end{tabular}




\begin{tabular}{|c|c|c|c|c|c|}
\hline $\begin{array}{l}\text { Aşağıda yer alan ifadeleri; } \\
\text { Market ürünleri (gıda, temizlik, kozmetik ve kişisel bakım } \\
\text { ürünleri) } \\
\text { Mağaza ürünleri (giyim, ayakkabı ,aksesuar, çanta, beyaz } \\
\text { eşya, ev elektroniği, mobilya, küçük ev aletleri, oyun ve } \\
\text { eğlence setleri) } \\
\text { Pahalı ve Lüks ürünler (otomobil, ev, pahalı elektronik } \\
\text { ürünler, pahalı mobilyalar, sanatsal ürünler, mücevher, } \\
\text { koleksiyon ürünleri) } \\
\text { şeklinde parantez içinde yer alan ürün kategorilerini göz } \\
\text { önünde bulundurarak değerlendiriniz. }\end{array}$ & 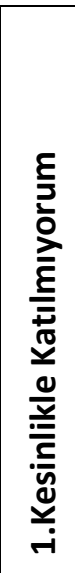 & 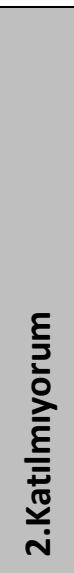 & $\begin{array}{l}\varepsilon \\
\frac{\varepsilon}{N} \\
\frac{N}{N} \\
\frac{\tilde{J}}{m} \\
m\end{array}$ & 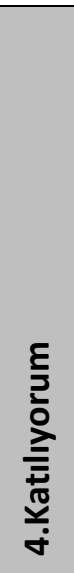 & 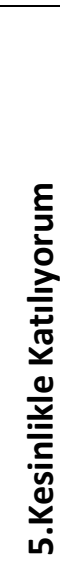 \\
\hline $\begin{array}{l}\text { 11. Market ürünlerinde yerli markalar yabancı } \\
\text { markalardan daha iyidir. }\end{array}$ & 1 & 2 & 3 & 4 & 5 \\
\hline $\begin{array}{l}\text { 12. Mağaza ürünlerinde yerli markalar yabancı } \\
\text { markalardan daha iyidir. }\end{array}$ & 1 & 2 & 3 & 4 & 5 \\
\hline $\begin{array}{l}\text { 13. Pahalı ve lüks ürünlerde yerli markalar yabancı } \\
\text { markalardan daha iyidir. }\end{array}$ & 1 & 2 & 3 & 4 & 5 \\
\hline $\begin{array}{l}\text { 14. Market alışverişinde aynı kaliteye sahip iki markadan } \\
\text { yerli olanı tercih ederim. }\end{array}$ & 1 & 2 & 3 & 4 & 5 \\
\hline $\begin{array}{l}\text { 15. Mağaza alışverişinde aynı kaliteye sahip iki markadan } \\
\text { yerli olanı tercih ederim. }\end{array}$ & 1 & 2 & 3 & 4 & 5 \\
\hline $\begin{array}{l}\text { 16. Pahalı ve lüks ürün alışverişinde aynı kaliteye sahip iki } \\
\text { markadan yerli olanı tercih ederi. }\end{array}$ & 1 & 2 & 3 & 4 & 5 \\
\hline $\begin{array}{l}\text { 17. Market alışverişinde yerli ürün gittiğim yerde yoksa o } \\
\text { ürünü başka yerde ararım. }\end{array}$ & 1 & 2 & 3 & 4 & 5 \\
\hline $\begin{array}{l}\text { 18. Mağaza alışverişinde yerli ürün gittiğim yerde yoksa o } \\
\text { ürünü başka yerde ararım. }\end{array}$ & 1 & 2 & 3 & 4 & 5 \\
\hline $\begin{array}{l}\text { 19.Pahalı ve lüks ürün alışverişinde yerli ürün gittiğim } \\
\text { yerde yoksa o ürünü başka yerde ararım. }\end{array}$ & 1 & 2 & 3 & 4 & 5 \\
\hline $\begin{array}{l}\text { 20. Market alışverişinde yabancı bir markada indirim varsa } \\
\text { yerli marka yerine onu tercih ederim. }\end{array}$ & 1 & 2 & 3 & 4 & 5 \\
\hline $\begin{array}{l}\text { 21. Mağaza alışverişinde yabancı bir markada indirim varsa } \\
\text { yerli marya yerine onu tercih ederim. }\end{array}$ & 1 & 2 & 3 & 4 & 5 \\
\hline $\begin{array}{l}\text { 22. Pahalı ve lüks ürün alışverişinde yabancı bir markada } \\
\text { indirim varsa yerli marka yerine onu tercih ederim. }\end{array}$ & 1 & 2 & 3 & 4 & 5 \\
\hline $\begin{array}{l}\text { 23. Market ürünlerinde yabancı markalı biri ürün satın } \\
\text { almak benim için statü ve itibar simgesidir. }\end{array}$ & 1 & 2 & 3 & 4 & 5 \\
\hline $\begin{array}{l}\text { 24. Mağaza ürünlerinde yabancı markalı ürün satın almak } \\
\text { benim için statü ve itibar simgesidir. }\end{array}$ & 1 & 2 & 3 & 4 & 5 \\
\hline $\begin{array}{l}\text { 25. Pahalı ve lüks ürünlerde yabancı markalı ürün satın } \\
\text { almak benim için statü ve itibar simgesidir. }\end{array}$ & 1 & 2 & 3 & 4 & 5 \\
\hline
\end{tabular}




\begin{tabular}{|c|c|c|c|c|c|}
\hline $\begin{array}{l}\text { Aşağıda yer alan ifadeleri katılma derecenize göre sizin için } \\
\text { en uygun seçeneği işaretleyiniz. }\end{array}$ & 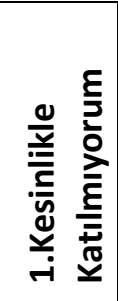 & 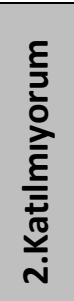 & 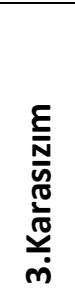 & 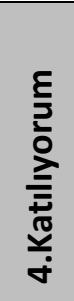 & 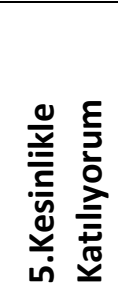 \\
\hline $\begin{array}{l}\text { 1. Yabancı ürünler yerine her zaman yerli ürünler satın } \\
\text { alınmalıdır. }\end{array}$ & 1 & 2 & 3 & 4 & 5 \\
\hline 2. Sadece, Türkiye'de üretilmeyen ürünler ithal edilmelidir. & 1 & 2 & 3 & 4 & 5 \\
\hline $\begin{array}{l}\text { 3. Yerli ürünler satın alınarak Türkiye'nin istihdamı } \\
\text { artırılmalıdır. }\end{array}$ & 1 & 2 & 3 & 4 & 5 \\
\hline $\begin{array}{l}\text { 4. Türkiye'de üretilen ürünler her zaman benim için } \\
\text { önceliklidir. }\end{array}$ & 1 & 2 & 3 & 4 & 5 \\
\hline 5. Yabancı ürünleri satın almak milli bir davranış değildir. & 1 & 2 & 3 & 4 & 5 \\
\hline $\begin{array}{l}\text { 6. Yabancı ürünleri satın almak doğru değildir çünkü } \\
\text { vatandaşların işsiz kalmasına neden olur. }\end{array}$ & 1 & 2 & 3 & 4 & 5 \\
\hline $\begin{array}{l}\text { 7. Gerçek bir Türkiye vatandaşı her zaman yerli ürünleri } \\
\text { satın almalıdır. }\end{array}$ & 1 & 2 & 3 & 4 & 5 \\
\hline $\begin{array}{l}\text { 8. Diğer ülkelerin bize mal satarak zengin olmasına } \\
\text { müsaade etmek yerine Türkiye'de üretilen ürünleri satın } \\
\text { almalıyız. }\end{array}$ & 1 & 2 & 3 & 4 & 5 \\
\hline 9. Her zaman en doğrusu yerli ürünleri satın almaktır. & 1 & 2 & 3 & 4 & 5 \\
\hline $\begin{array}{l}\text { 10.Gerekli olmadığı sürece diğer ülkelerle ürün ticareti } \\
\text { veya satın alımı çok az olmalıdır. }\end{array}$ & 1 & 2 & 3 & 4 & 5 \\
\hline $\begin{array}{l}\text { 11. Türkiye'nin ticaretine zarar verip, işsizliğe yol açtığı için } \\
\text { vatandaşlar yabancı ürün satın almamalıdır. }\end{array}$ & 1 & 2 & 3 & 4 & 5 \\
\hline 12. Yabancı ürünlerin ithalatına kısıtlamalar getirilmelidir. & 1 & 2 & 3 & 4 & 5 \\
\hline $\begin{array}{l}\text { 13. Uzun vadede bana daha maliyetli olsa da yerli ürünleri } \\
\text { satın almayı tercih ederim. }\end{array}$ & 1 & 2 & 3 & 4 & 5 \\
\hline $\begin{array}{l}\text { 14. Yabancıların ürünlerini bizim pazarımızda satılmalarına } \\
\text { izin verilmemelidir. }\end{array}$ & 1 & 2 & 3 & 4 & 5 \\
\hline $\begin{array}{l}\text { 15. Yabancı ürünlerin Türkiye'ye girişlerini azaltmak için, } \\
\text { yüksek oranda vergilendirilmelidir. }\end{array}$ & 1 & 2 & 3 & 4 & 5 \\
\hline $\begin{array}{l}\text { 16. Sadece kendi ülkemizde bulamadığımız ürünleri, } \\
\text { yabancı ülkelerden satın almalıyız. }\end{array}$ & 1 & 2 & 3 & 4 & 5 \\
\hline $\begin{array}{l}\text { 17. Yabancı ürünleri satın almayı tercih eden tüketiciler, } \\
\text { kendi ülke vatandaşlarının işsiz kalmalarından } \\
\text { sorumludurlar. }\end{array}$ & 1 & 2 & 3 & 4 & 5 \\
\hline
\end{tabular}

